\title{
Review and phylogeny of the genus Tillobroma Hull with the description of ten new species and its relation with the genus Hypenetes Loew (Diptera, Asilidae, Stenopogoninae)
}

\author{
Revisión y filogenia del género Tillobroma Hull con la descripción de diez nuevas especies \\ y su relación con el género Hypenetes Loew (Diptera, Asilidae, Stenopogoninae)
}

\author{
JORGE N. ARTIGAS ${ }^{1}$, PETER D. LEWIS ${ }^{2} \&$ LUIS E. PARRA $^{1}$
}

\begin{abstract}
${ }^{1}$ Departmento de Zoología, Facultad de Ciencias Naturales y Oceanográficas, Universidad de Concepción, Casilla 160-C; Concepción-Chile; e-mail: jartigas@udec.cl; luparra@udec.cl

${ }^{2}$ Teaching Council, University of Concepción, Concepción, Chile; e-mail: plewis@udec.cl
\end{abstract}

\begin{abstract}
This paper examines the status and geographic distribution of the genera Hypenetes Loew and Tillobroma Hull; the status of the latter was shifted to generic level by Artigas \& Papavero 1991. The genus Clavator Philippi, which is preoccupied, becomes synonymous to Tillobroma Hull, this has been proposed by Artigas \& Papavero (1991), and is confirmed here. Hypenetes and Tillobroma have a possible common Gondwanan origin of approximately 180 millions years ago. Even though the external characters barely allow separation between the two genera, the obvious differences in spermathecae structures permit the inference of other internal differences and reinforce the independent status of the genera. This conclusion is also supported by 180 million years of interrupted genetic drift and the $8,500 \mathrm{~km}$ distance between the populations. A key to separate the species of Tillobrama is provided. Of a total of 21 species, ten are new for science: aconcaguana, angulata, fucosoides, huasquina, leucoptera, leucotrica, nahuelbutae, purpurea, spinipes and tregualemuensis. The species belonging to this genus are distributed in Argentina, Bolivia, Brazil, Paraguay, Peru and especially Chile (where 19 of 21 are found). A phylogenetic study for the species in the genus was performed. Two South African species, Hypenetes grisescens Engel and Hypenetes stigmatias Loew, were used as external group. The software used was NONA 2.0 (heuristic search). The tree of strict consensus separated the out group by nine synapomorphies from the species H. stigmatias with four autopomorphies.
\end{abstract}

Key words: taxonomy, Asilidae, Tillobroma, Hypenetes, new species, morphology.

\section{RESUMEN}

Se estudia el estatus y la distribución geográfica de los géneros Hypenetes Loew y Tillobroma Hull, este último elevado al rango de género por Artigas \& Papavero (1991). El género Clavator Philippi está preocupado y es sinónimo de Tillobroma Hull, lo que fue propuesto por Artigas y Papavero 1991 y confirmado en el presente trabajo. Se concluye que Hypenetes y Tillobroma tienen un posible origen gondwánico común desde aproximadamente 180 millones de años. Aunque los caracteres externos difícilmente permiten separar las especies de ambos géneros, las notables diferencias en las espermatecas, que permiten inferir otras diferencias internas, aseguran el estatus independiente de ambos géneros, avalado además por 180 millones de años de interrupción del flujo genético y de $8.500 \mathrm{~km}$ de distancia entre ambas poblaciones. El estudio filogenético del género Tillobroma, usando dos especies sudafricanas como grupo externo: Hypenetes grisescens Engel e Hypenetes stigmatias Loew, muestra nueve sinapomorfías que sustentan la monofilia de Tillobroma. Se incluye una clave para separar las especies de Tillobroma. De las 21 especies tratadas, diez son nuevas para la ciencia: aconcaguana, angulata, fucosoides, huasquina, leucoptera, leucotrica, nahuelbutae, purpurea, spinipes y tregualemuensis. Las especies del género están distribuidas en: Argentina, Bolivia, Brasil, Paraguay, Perú y, principalmente Chile (19 de 21).

Palabras clave: taxonomía, Asilidae, Tillobroma, Hypenetes, nuevas especies, morfología. 


\section{INTRODUCTION}

The genus Clavator Philippi 1865: 699-701, was described for five Chilean species: punctipennis Philippi, nigribarbis Philippi, rubricornis Philippi, brevicornis Philippi and rufescens Philippi. By page priority, the type species is punctipennis Philippi (Hull 1962, 152). Of the five species described by Philippi, only punctipennis remains linked to Hypenetes (= Clavator); the rest should be relocated as follows: brevicornis in Alyssomyia Hull and rufescens, nigribarbis and rubricornis in Creolestes Hull (Hull 1962). Reed (1888) placed Clavator Philippi as a junior synonym of Hypenetes Loew.

Hull (1962), in his monograph on the world's Asilidae genera, considered Clavator Philippi as a junior synonym of Hypenetes Loew 1858. He divided the species Hypenetes in two groups. The first group confined to the neotropics: asiliformis Wulp 1882; fulvicornis Macquart 1846; nigribarbis Philippi 1865; obtusus Engel 1930; punctipennis Philippi 1865; rubricornis Philippi 1865; rufescens Philippi 1865 and tertialis Bromley 1932. The second group being afro tropical: grisescens Engel 1929; stigmatias Loew 1858. He also created the sub-genus Tillobroma, in which he included Clavator punctipennis Philippi 1865. He distinguished Hypenetes species of Africa from those of South America. The characters used by this author to separate both are relative and subjective, such as body and proboscis size, and body robustness. One valuable observation was that the occippital hair (postocular) should be thicker and longer in the South American species, and that would be included in the sub-genus Tillobroma. However, this character is not constant.

Artigas (1970), in his monograph on Chilean Asilidae, reviewed the species Hypenetes (sensu Hull), of which he recognized: asiliformis Wulp 1882 and punctipennis Philippi 1865; and added new species: critesi Artigas, davidsoni Artigas, digitatus Artigas, fucosus Artigas, magellanicus Artigas, schineri Artigas and valentinei Artigas. Oldroyd (1974) presented an introduction to South African Asilidae, where he recognized for the genus Hypenetes, the species grisescens Engel 1929 and stigmatias Loew 1858. He added the new species: morosus
Oldroyd, rotundus Oldroyd, irwini Oldroyd, nigrispina Oldroyd, galactodes Oldroyd (Hermann in litt.), greatheadi Oldroyd, miles Oldroyd and sturmias Oldroyd. Londt 1985 reviewed the afro tropical Asilidae of the genus Hypenetes Loew, where Clavator Philippi is accepted as a junior synonym of Hypenetes. He recognized the species: galactodes Oldroyd 1974, greatheadi Oldroyd 1974, grisescens Engel 1929, irwini Oldroyd 1974, morosus Oldroyd 1974, rotundus Oldroyd 1974, stigmatias Loew and sturmias Oldroyd 1974. He added the new species: aegialodes Londt, argothrix Londt, cryodes Londt, dicranus Londt, dorattina Londt, hessei Londt, loewi Oldroyd, macrocercus Oldroyd, oldroydi Londt, pylochrysites Londt, rexi Londt, stuckenbergi Londt and turneri Londt.

Artigas \& Papavero (1991), in their review of the American genera of Asilidae, raised Tillobroma Hull, 1962 from subgenus to genus, creating the tribe Tillobromatini Artigas and Papavero, and placed the American species in it. They did not use Clavator Philippi because it was preoccupied by Martens 1860. They recognized the species: asiliformis Wulp 1882, davidsoni Artigas 1970, digitatus Artigas 1970, fucosus Artigas 1970, fulvicornis Macquart 1846, magellanicus Artigas 1970, obtusus Engel 1930, punctipennis Philippi 1865, schineri Artigas 1970 and valentinei Artigas 1970. Based on this historical review of the genera Clavator Philippi, Hypenetes Loew and Tillobroma Hull, it is believed that Hypenetes and Tillobroma are two valid genera, each one from a different continent. Their origin should be Gondwanan, where possible existed a protogenus, "Clavator-Tillobroma" (Fig. 1A) during the middle Jurassic period (180 million years ago), and its population was divided before the upper Cretaceous period (70 million years ago), forming two populations that continued their evolution separately until the present.

The conclusion is that the populations are distinctive, with an unfeasible genetic drift between them for the last 170 million years approximately. These evidences allow us to present the hypothesis for vicariance, its total taxonomic separation, despite the morphological coincidences that many authors have pointed out in the past. The objective of this work was to identify the differences produced since that moment. 

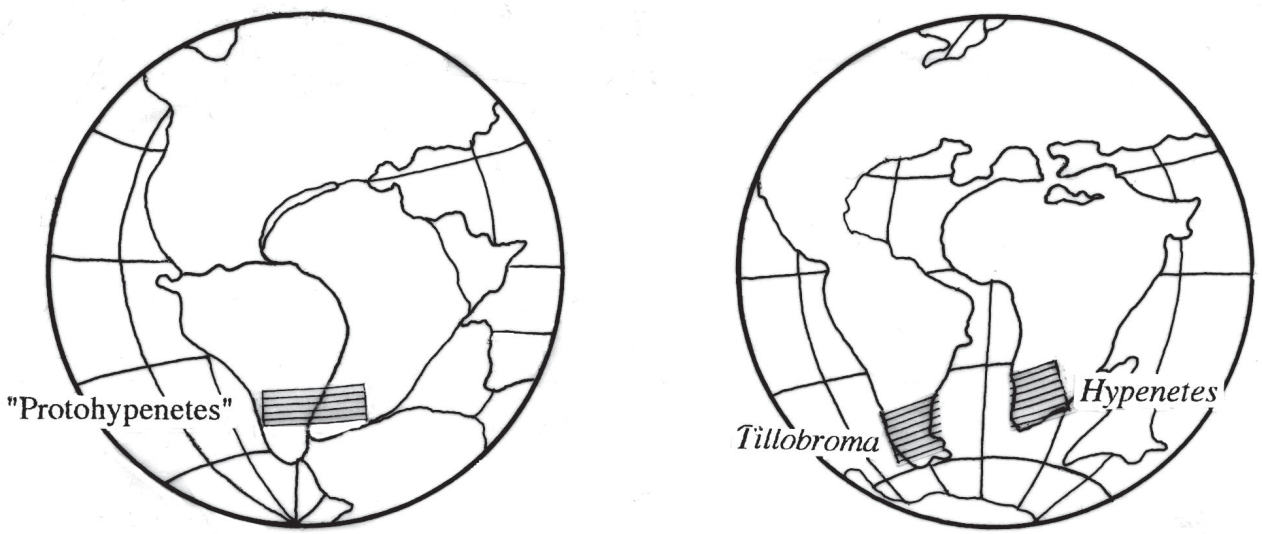

MIDDLE JURASSIC 180 MILLION YEARS SUPERIOR CRETACIC 70 MILLION YEARS
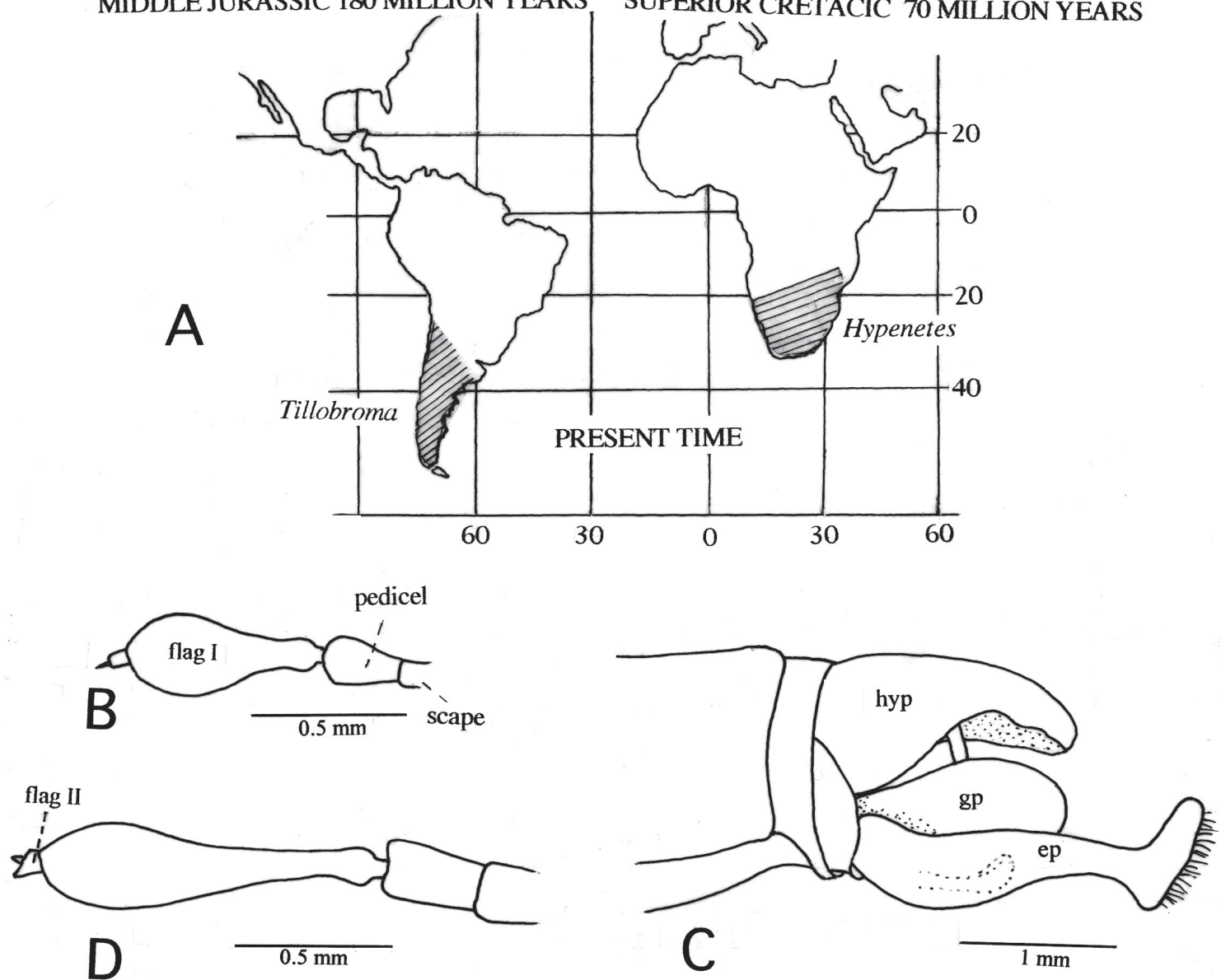

Fig. 1: (A) Map of Gondwana Continent in Middle Jurassic with the estimated distribution of the genus "proto Hypenetes - Tillobroma". Distribution of Hypenetes and Tillobroma in South America and Africa in Superior Cretacic and in present time; (B) Hypenetes stigmatias (Loew), antenna side view and (C) male genitalia side view; (D) Hypenetes grisescens Engel, antenna side view.

(A) Mapa del Continente Gondwana en el Jurásico Medio con una distribución tentativa del género "proto HypenetesTillobroma". Distribución de Hypenetes y Tillobroma en Sudamérica y Africa en el Cretácico Superior y, en tiempo presente. (B) Hypenetes stigmatias (Loew) antena en vista lateral y (C) genitalia del macho en vista lateral. (D) Hypenetes grisescens Engel, antena en vista lateral. 
Separation of the Genera Hypenetes Loew and Tillobroma Hull

The species of both genera present numerous external morphological similarities, supporting that Hypenetes Loew had a Gondwanan origin and that its distribution included the species from southern South America and southern Africa (afro tropical). Londt 1985, stated that the genus Hypenetes might exist exclusively in the afro-tropical region and that the South American species should be excluded from it and "probably placed in combination with the genus Clavator Philippi which had been considered a synonym of Hypenetes."

Londt's work provided male genitalia figures for all 21 afro tropical species, allowing the differences in hypandria and the epandria to be compared sharply with most of the 21 South American species (coincident number of species). Authors such as Papavero (1973; 246) and Londt (1985: 377, 26), discussed the hypothesis that both genera belong to a single genus with Godwanan distribution. The differences between these genera mentioned are subjective, such as size, robustness, thickness of ocular hairs, length of proboscis and presence of a stigmal spot on the wing. These differences are also found among various species within each group. The lack of betterdefined characters supports the thesis of a single gondwanan genus. The differences found in this investigation allows the acceptance of a different thesis, which is that the two sets of species are distinct, even though they are sister groups and derived from a common gondwanan trunk.

The super continent Gondwana broke apart approximately 70 million years ago (Fig. 1A). In that evolutionary historic moment Asilidae began a vicariant process of speciation, as happened with other life forms of the supercontinent. On the other hand, the gondwanan genus, that was the ancestral trunk of Hypenetes and Tillobroma, probably had many of the characters shared by both genera today. On the contrary, similarities on body shape, antennae, wing venation and integumentary elements might have arisen due to evolutionary convergence. The difference between the male genital armor is minor and can be attributed to expansion and elongation. At present there are characters to recognize both genera, but anyway a greater similar state exists between these genera than between others of Asilidae. These structures provide the character state that groups both genera close, and that leads to the two hypotheses of the present study. Available morphological evidence indicates that these two genera are likely distinct, which makes sense, because they probably have been separated for a long time.

\section{MATERIAL AND METHODS}

McAlpine (1981) nomenclature was followed for external morphology (Fig. 5A). For the spermathecae, Artigas (1971) and Theodor (1980) nomenclatures were followed. De La Torre-Bueno (1989) was used as general entomology dictionary. Wing length is in millimeters from the thorax union to the apex. The length of the body was taken from front to the posterior apex of the hypandrium. The male genitalia were drawn directly from the natural state, except in occasions when there was a need for grater detail. On such occasions, the genitalia were placed in a $\mathrm{NaOH}$ solution for aedeagus extraction. Hairs and bristles were not included in figures. Figures of the ovipositor were drawn using dried specimens. For preparation and drawing of spermathecal structures, the abdomen was removed at the thoracic union and boiled in a $10 \% \mathrm{KaOH}$ solution for one hour, until the abdomen became transparent enough to allow the drawing of the general plan of the spermathecae, which was presented in schematic figures, with the capsules position marked for each spermathecae (Fig. 16E) (reservoir acc. Theodor 1980: 18). After all glandular tissue was removed by the $\mathrm{KaOH}$, the remaining chitinous parts of the spermathecae were extracted through careful dissection, in order to maintain the general tube arrangement in relation to the capsules. The integrity of the furca (IX sternite) was carefully obtained by removing its internal connection with the integument, then slide mounted in glycerin and drawn using a microscope equipped with a camera lucida. Genitalia and leg figures did not include hairs and bristles for better structures clarity, unless otherwise indicated. Figure legends specified when type material were used 
for the drawings, and specimen label data has been transcribed verbatin in the text. Additional information, when needed, was added within brackets.

\section{Studied material}

This research studied 536 samples stored in the Zoology Museum of the University of Concepción (MZUC-UCCC) and in the Natal Museum of South Africa (for the species of Hypenetes Loew).

\section{Phylogenetic analysis}

Out group comparison in the phylogenetic analysis was used, and were two South African species belonging to the genus Hypenetes Loew: H. grisescens Engel and H. stigmatias Loew. These species were chosen because they represent a sister group of the species distributed in southern South America. The information was analyzed using the software NONA 2.0. (Goloboff 1993), running with WINCLADA 0.9.99.50 mexu (BETA) (Nixon 2002). The analysis included all characters unordered. The matrix was analyzed using 50 replicates, a hazard additional sequence, and a branch permutation of the type "tree bisection reconnection" (TBR) (Swofford \& Olsen 1990). A key to the abbreviations used is given in Appendix 1.

\section{RESULTS}

\section{Taxonomy}

Genus Tillobroma Hull.

Hypenetes Loew, 1858: 349 (part); Reed, 1888: 18; Bromley, 1932: 264; Hull, 1962: 154; Artigas, 1970: 124. Type: Hypenetes stigmatias Loew (monotypy).

Clavator Philippi, 1865: 699 (preoc. Martens, 1860); Londt, 1985: 377. Type: Tillobroma [Clavator, Hypenetes] punctipennis Philippi (first of five species).

Tillobroma Hull, 1962: 154; Papavero, 1973: 246 (n. status); Artigas y Papavero, 1991: 18, 26. Type of subgenus: Clavator punctipennis Philippi (by original designation).

Type species of the genus: Tillobroma [Clavator] punctipennis Philippi (priority).
Diagnosis: this genus is placed in the tribe Tillobromini Artigas and Papavero, 1991, in the subfamily Stenopogoninae Hull, 1962. Differs from other genera of the tribe by the mystax and heavy bristles, occupying most of the facial gibbosity and mixed with few hairs (Fig. 4 and 5A); the anterior dorsocentral bristles are mixed with moderately and more or less abundant long pilosity; facial gibbosity well developed; first flagellomere narrower on the basal third and then expanded from the middle up. Male genitalia rotated $180^{\circ}$, the hypandrium is attenuated towards the apex covering the upper part of the genitalia; apex usually pointed (Fig. 12B), blunt (Fig. 14B) or spatulate (Fig. 26C 26D). When pointed or blunt, hypandrium carries, in some species, a pair of spines of variable length but constant within species (Fig. 22B). Gonopods are globular at base and, in some species, each gonocoxites bear a distal process which is variable among but constant within species; epandria simple, long, in most species its distal margin reaching hypandrium. Epandrium does not have apical extensions or expansions (Fig. 14B), as are found in its sister group Hypenetes Loew (Figs. 1C and 2A). Ovipositor is truncate, with four to six spines on each acanthophorite (Fig. 9B), differing from the genus Hypenetes, which has eigth to nine spines on each acanthophorite (Fig. 2B). The spermatheca has capsules located in abdominal segments three to five, and in all species they form flat spirals, with two and a half loops (Fig. 3) (in Hypenetes, the capsules are globular and located in the seventh abdominal segment); the capsular ducts vary in length from four to fifteen times the length of the furca.

Wings (Fig. 5B) reach beyond apex of the abdomen. Cells $\mathrm{r} 1$ and $\mathrm{m} 3$ are open; alulae poorly developed; R4 reaches the wing border before the apex of the wing, and R5 reaches it always after the apex; cuP cell open; color variable, from hyaline to fumose dark brown, with brown veins. In T. leucoptera $\mathrm{n}$. sp. and $T$. robusta Engel, the basal half of male wings are milky white. Only the basal third of the wing may be white, with the remainder hyaline, as in $\mathrm{T}$. spinipes $\mathrm{n}$. sp. Legs are strong, one colored femora, which separates this genus from Hypenetes, where 20 out of 21 species have the femora longitudinally bicolor (Londt 1985: 377-405). Some species have spiny bristles on ventral and lateroventral portions of hind 


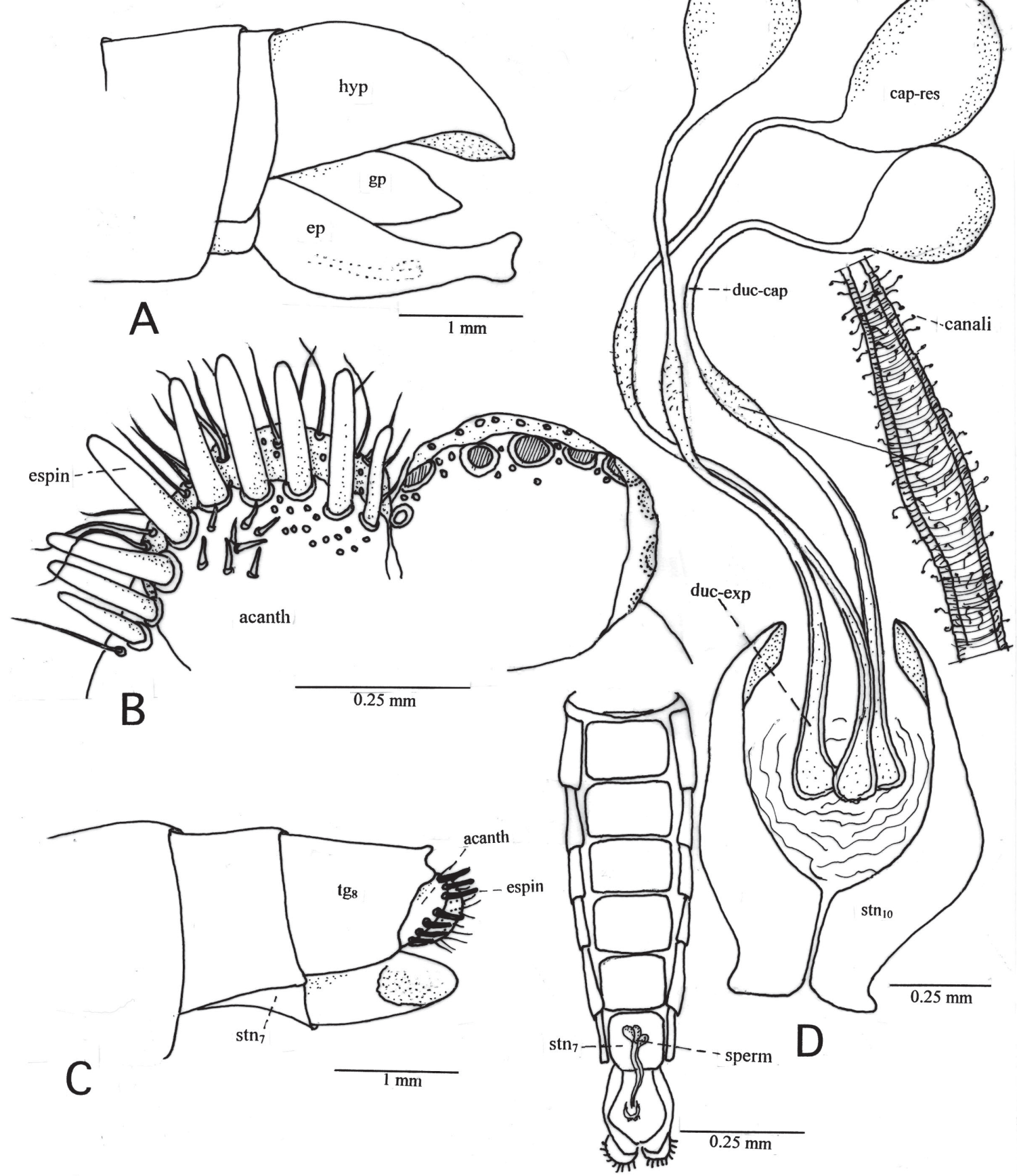

Fig. 2: Hypenetes grisescens Engel. (A) Male genitalia in side view; (B) acanthophorites (KOH); (C) ovipositor in side view; (D) abdomen in ventral view shows position of spermatheca; spermatheca $(\mathrm{KOH})$ and details.

Hypenetes grisescens Engel. (A) Genitalia del macho en vista lateral; (B) acantoforites (KOH); (C) ovipositor en vista lateral; (D) abdomen en vista ventral, muestra posición de espermateca; espermateca (KOH) y detalles. 

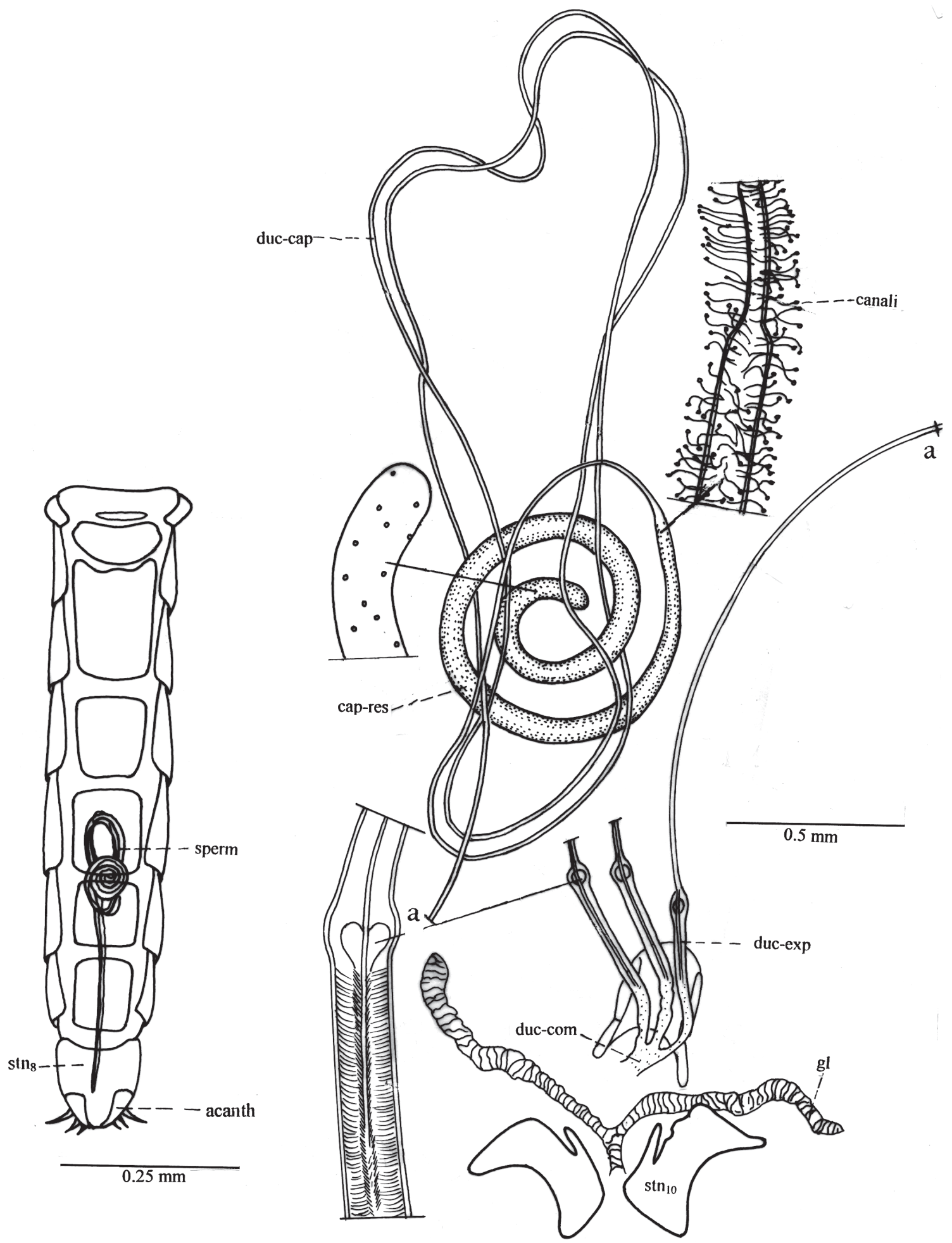

Fig. 3: Tillobroma punctipennis (Philippi). Abdomen in ventral view, shows position of the spermatheca; spermatheca $(\mathrm{KOH})$ and details.

Tillobroma punctipennis (Philippi). Abdomen en vista ventral, muestra posición de espermateca; espermateca (KOH) y detalles. 


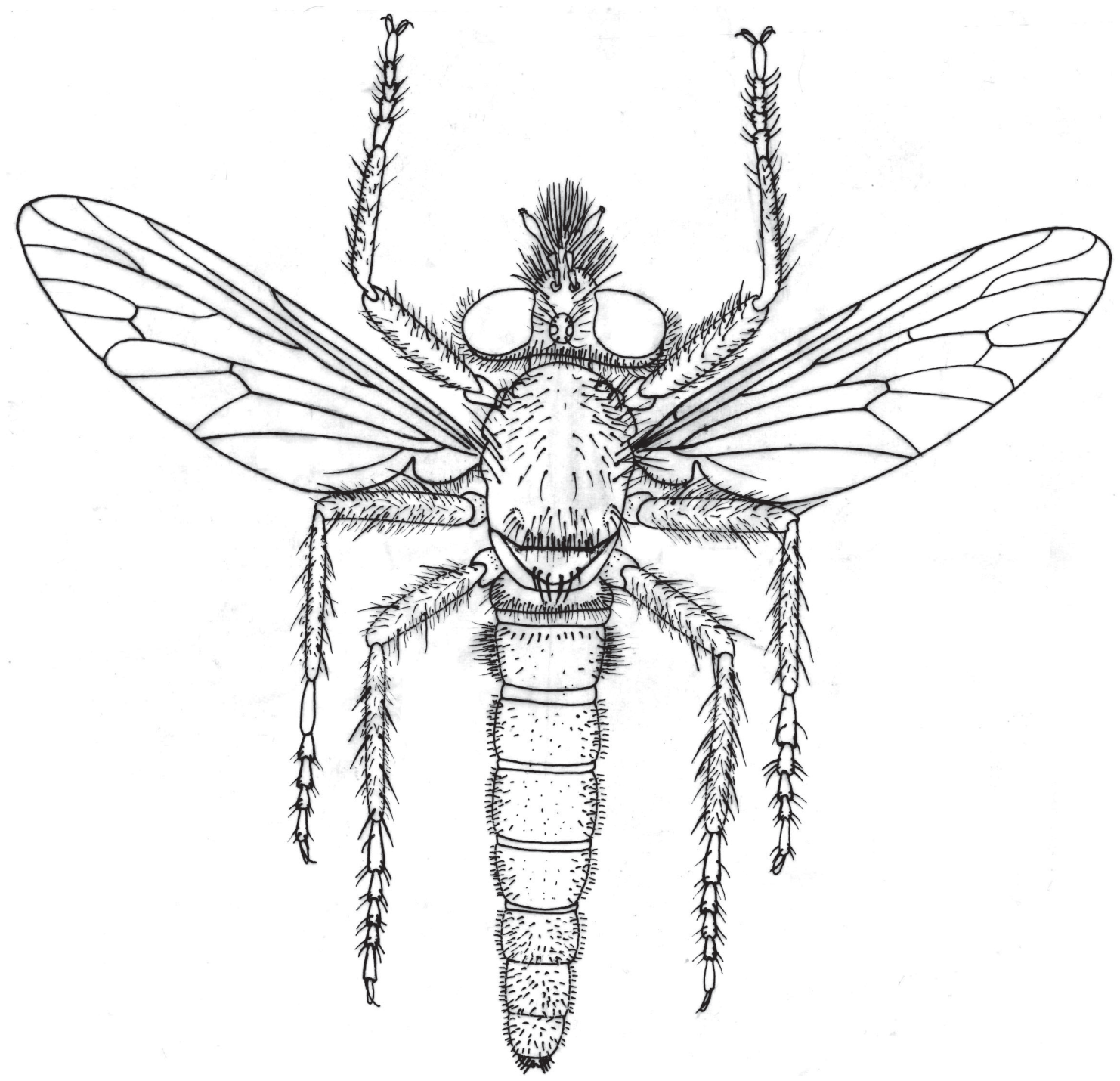

Fig. 4: Tillobroma valentinei (Artigas). Female, body in dorsal view. Tillobroma valentinei (Artigas). Hembra, cuerpo en vista dorsal. 


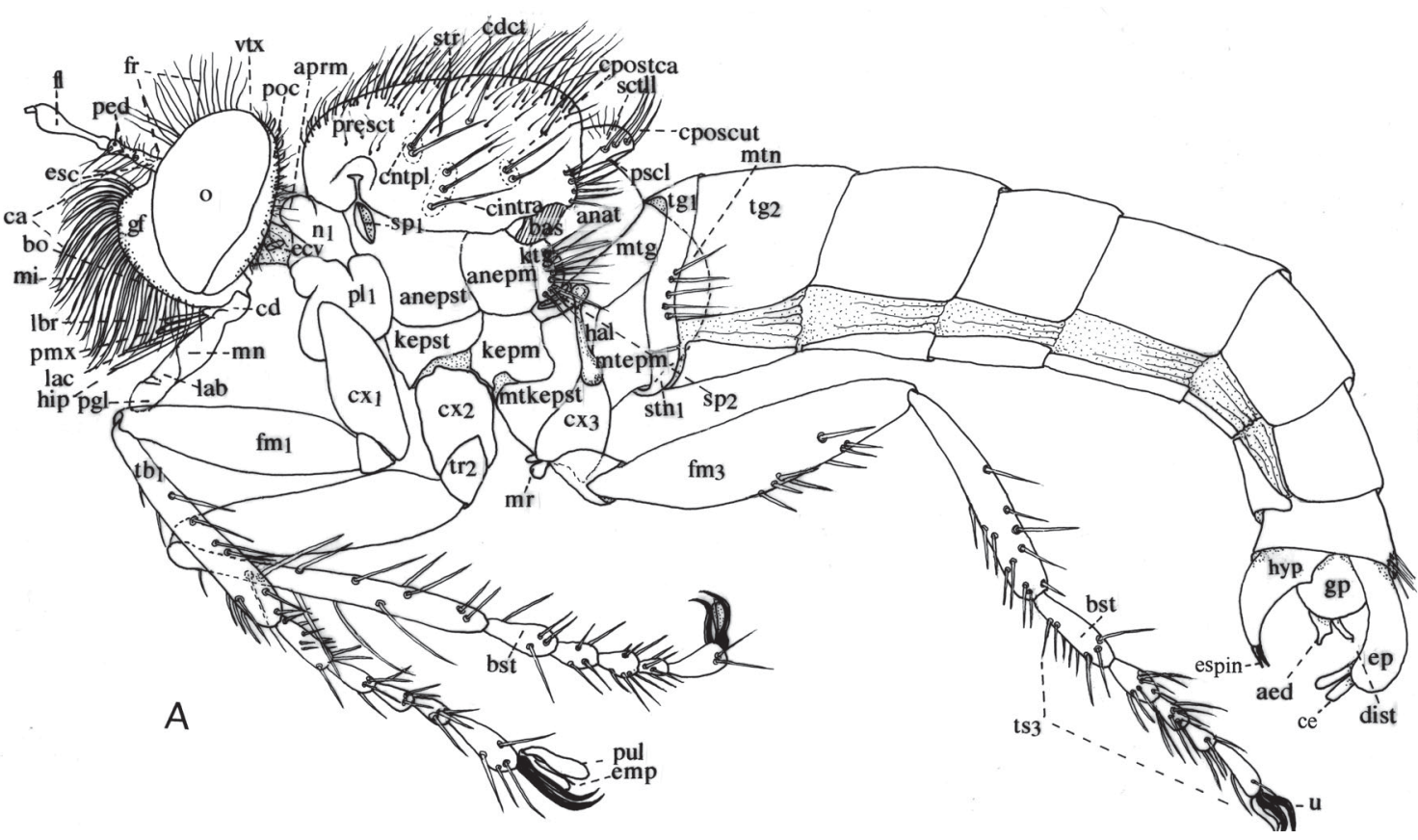

Fig. 5: (A) Tillobroma punctipennis (Philippi), male. Labeled scheme in side view (hairs omited), genitalia not rotated in $180^{\circ}$; aed aedeagus; anat anatergite; anepm anepimeron;

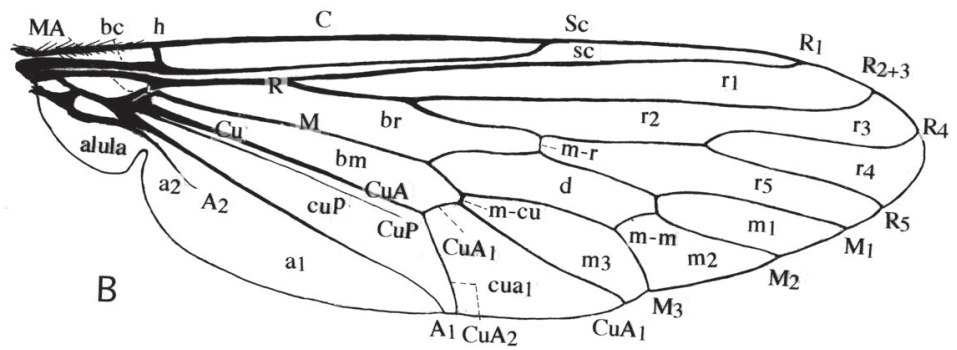
anepst anepisternum; aprm antepronotum; bas basistilus; bo mouth (cavity); bst basitarsus; ca face; $c d$ cardo; $c d c t$ dorsocentral bristles; cintra intraalar bristles; cntpl notopleural bristles; cposcut post scutellar bristles; cpostca post callar bristles; $c x 1$ fore coxa; $c x 2$ medial coxa; $c x 3$ hind coxa; dist dististylus; ecv cervical sclerite; emp empodium; ep epandrium; esc scapo; esp spine (from hypandrium); $f l$ flagellum; $f m l$ anterior femur; $f m 3$ hind femur; $f r$ frons; $g b$ facial gibbosity; gp gonopod; hal halter; hip hypopharynx; hyp hypandrium; kepm katepimeron; kepst katepisternum; ktg katatergite; lab labium; lac lacinia; lbro labro; mi mystax; mn mentum; $m r$ meron; mtepm metepimeron; $m t g$ metatergite; mtkepst metakatepisternum; $m$ tn metanotum; $n l$ pronotum; $o$ eye; ped pedicellus; $p g l$ paraglossa; $p l l$ propleuron; $p m x$ maxillary palpus; poc postocular (area); presct prescutellum; pscl postscutellum; pul pulvillus; sctll scutellum; spl anterior spiracle; sp2 mesothoraxic spiracle; $s t n 1$ first sternite; str transversal suture; $t b 1$ anterior tibia; $\operatorname{tg} 1$ tergite 1; $\operatorname{tg} 2$ tergite 2; $\operatorname{tg} 8$ tergite 8 ; $\operatorname{tr} 2$ middle trochanter; $t s 3$ hind tarsus; $u$ nail; vtx vertex. $(B)$ : Wing labeled (neotype).

Tillobroma punctipennis (Philippi), macho. Esquema en vista lateral rotulado (pelos omitidos), genitalia no rotada en $180^{\circ}$ : aed aedeago; anat anatergito; anepm anepimeron; anepst anepisterno; aprm antepronoto; bas basistilo; bo boca (cavidad); bst basitarso; ca cara; $c d$ cardo; cdct cerdas dorsocentrales; cintra cerdas intraalares; cntpl cerdas notopleurales; cposcut cerdas postescutelares; cpostca cerdas post calares; $c x 1$ coxa anterior; $c x 2$ coxa mediana; $c x 3$ coxa posterior; dist dististilo; ecv esclerite cervical; emp empodio; ep epandrio; esc escapo; esp espina (del hipandrio); $f l$ flagelo; $f m l$ fémur anterior; $f m 3$ femur posterior; $f r$ frente; $g b$ giba facial; $g p$ gonopodo; hal haltere; hip hipofaringe; hyp hipandrio; kepm katepimeron; kepst katepisterno; ktg katatergito; lab labio; lac lacinia; lbro labro; mi mistax; mn menton; mr meron; mtepm metepimeron; mtg metatergito; mtkepst metakatepisterno; mtn metanoto; $n 1$ pronoto; o ojo; ped pedicelo; pgl paraglosa; $p l l$ propleuron; pmx palpo maxilar; poc postocular (area); presct prescutelo; pscl postscutelo; pul pulvilo; sctll scutelo; spl espiráculo anterior;'sp2 espiráculo mesotorácico; stnl primer esternite; str sutura transversal; $t b 1$ tibia anterior; $\operatorname{tg} 1$ tergite 1; $\operatorname{tg} 2$ tergito $2 ; \operatorname{tg} 8$ tergito $8 ; \operatorname{tr} 2$ trochanter mediano; $\operatorname{ts} 3$ tarso posterior; $u$ uña; $v \operatorname{tx}$ vertex. (B) Ala rotulada (neotipo). 
femora (Fig. 21G), most however have only 1-4 bristles near the apices of the femora. Tibiae have well defined bristles (Fig. 23E), mixed with fine and long hairs, mainly confined to the anterior and middle tibiae.

Geographic distribution: according to Fig. $30 \mathrm{~F}$.

Key to the species of Tillobroma Hull (confined to Chile unless indicated)

1 Mystax with bristles on upper, half thicker than those on basal half (Fig. 9C), in some species this difference is slight but distinguishable (Fig. 9C). Anterior tibiae with long, white bristles 2

1' Mystax with all bristles of similar thickness. Anterior tibiae with long bristles of colors other than white, or of mixed colors 4

2(1) Mystax all white. Bristles of mesonotum and scutellum white. Gonopods short and globular, with a short apical process directed posterior. Flagellomere as in Fig. 17E. Genitalia as in Fig. 17F-17G

leucotrica $\mathrm{n} . \mathrm{sp}$.

2 Upper half of mystax black, lower half white. Bristles of mesonotum and scutellum dark brown or black. Gonopods with an apical process bent inward .. 3

$3\left(2^{\prime}\right)$ Hind femora with 6 or more spiny bristles in ventral and lateroventral area. Front tibiae with short, fusiform hairs, depressed against integument. Sides of facial gibbosity with gray micropubescense, not shiny. Mesonotal bristles mixed: some short and white, some long and black. Hypandrium with 2 short, yellow or oranged red spines (Fig. 8H-8J). Ovipositor Fig. 9B. Head in side view as in Fig. 9C. Argentina and Chile... asiliformis (Wulp)

3. Hind femora without such bristle in ventral and lateroventral positions. Front tibiae with normal hairs. Sides of facial gibbosity mainly shiny black, with glabrous or scant micropubescence. Bristles of the mesonotum black, mixed with fine, sparse white hairs. Hypandrium with apical third narrow, its width equals the distance at the base of the two white, apical spines. Male genitalia as in Fig. 16B-16C. Ovipositor as in Fig. 16D. Flagellomere as in Fig. 16A.

huasquina $\mathrm{n} . \mathrm{sp}$.

4(1') Hind femur without spiny bristles in ventral and lateroventral positions; 1-2 spines possible near apex 7

4' Apical half of hind femora with at least 4 bristles in ventral and lateroventral positions; in some species very thick and spiny 5

5(4') Flagellomere reddish. Front tibiae with reddish integument. Male genitalia as in figs. 15B-15D. Ovipositor as in Fig. 15E and $15 \mathrm{~F}$. Flagellomere as in Fig. 15A. Brasil fulvicornis (Macquart)

5 Flagellomere black or dark colored. Front tibiae with black integument 6

$6\left(5^{\prime}\right)$ Bristles on katatergite black. Wings of uniform light brown color in both sexes, with small, faint spots. Front tibiae with long bristles, mainly reddish -yellow; black on hind tibiae. Hind femur with six or more thick, black bristles, shorter than basitarsus (Fig. 21G). Sides of facial gibbosity black or brown, shiny in part, some with purple reflection. Apex of hypandrium rounded, with two small parallel, black, spines. Gonopods globular, with the apical process hornshaped, directed dorsad. Cerci large, curved dorsad in a straight angle at the middle (Fig. 21B-21D). Ovipositor (Fig. 21E and F). Flagellomere (Fig. 21A). Hind femora and tibiae as in Fig. 21G. Wing (Fig. 5B) .... punctipennis (Philippi)

6' Bristles on katatergite white. Male wings slightly tinged milky white on basal third, the remainder without spots. Front tibiae with long white bristles, some as long as basitarsi. Sides of facial gibbosity with gray micropubescence, not shiny. Hypandrium with two divergent, reddish -yellow spines. 
Gonopods short, with the apex rounded. Cerci small, straight, slightly curved dorsad at apex. Male genitalia (Fig. 24B and $\mathrm{C}$ ). Ovipositor in side view (Fig. 24D). Flagellomere as in Fig. 24A. Argentina spinipes $\mathrm{n} . \mathrm{sp}$.

7(4) Front tibial integument black, or same color of corresponding femur, at least over $4 / 5$ of the length 8

7 Front tibial integument dark brown to reddish- brown, or lighter than the corresponding femur, at least over the basal half; apex may be black 12

8(7) Hind tibiae with very long black hairs, some two times as long as basitarsus; in ventral part of hind tibia a row of $2-5$ slender bristles, as long as basitarsus (Fig. 7E). Front tibiae with long and black hairs and bristles black or reddish-yellow. Bristles of notum and scutellum long and thin, similar to the hairs of hind tibiae. Male genitalia as in Fig. 7B and 7C. Ovipositor as in Fig. 7D. Flagellomere as in Fig. 7A aconcaguana $\mathrm{n}$. $\mathrm{sp}$.

8' Hind tibiae not as described above. Bristles of notum and scutellum not as described above 9

9(8')Mystax with black bristles on upper half and white on lower half, at least near the oral border. Katatergite with bristles mixed black and white. Cerci strongly recurved. Apical process of gonopods curved toward center and then slightly directed out, ending as a small club. Male genitalia as in Fig. 11B-11D. Ovipositor (Fig. 11E). Flagellomere (Fig. 11A). Hind tibia (Fig. 11F) davidsoni (Artigas)

9' Mystax with all bristles black. On katatergite bristles are white or black, or intermingled 10

10(9') Tergites on dorsal area with tenuous sub triangular spots of gray micropubescence. Front tibiae with all bristles reddish, rather short, no longer than the basitarsus.
Tip of hypandria spatulate, bilobular in distal margin (Fig. 26D), forming a straight angle directed downward, without apical spines. Male genitalia as in Fig. 26B-26D. Female in dorsal view as in Fig. 4. Ovipositor (Fig. 26E). Hind tibia (Fig. 26F). Flagellomere (Fig. 26A)

valentinei (Artigas)

10' Tergites shiny black on dorsal area, without micropubescence. Hind tibia with black or reddish-brown bristles, often intermingled. Apex of hypandrium blunt or acute, never spatulate or bilobular, slightly curved downward, with or without spines on apex ............................ 11

11(10')Flagellomere with the pedicel as long as the capitulum, as in Fig. 8A. Scutellum disc with fine black bristles. Hind femora with one or two thick bristles on external side. Front tibiae with two or three thick black bristles on external side, never more than five. Male genitalia not uniform in color, some parts are discolored; hypandrium blunt, without spines; gonopods with a distal process, curved toward center forming a straight angle and with the apex flattened. Male genitalia as in Fig. 8B-8D. Ovipositor (Fig. 8E). Hind tibia (Fig. 8F) angulata $\mathrm{n} . \mathrm{sp}$.

11' Flagellomere with a short pedicel, 1/4 or $1 / 5$ the length of capitulum as in Fig. 20A. Scutellar disc without bristles or hairs, or with few fine white hairs. Front tibiae with four long, reddish-bristles on external side. Hind femora with three or four (usually four) thick bristles on external side, arranged in line. Male genitalia uniformly reddish- brown, hypandrium could be lighter; hypandrium ends pointed, with two reddish-yellow, middle sized spines, parallel on all its extension; gonopods globular, short, with a rounded apical process directed backwards. Male genitalia (Fig. 20B and C). Ovipositor (Fig. 20D). Flagellomere (Fig. 20A) nahuelbutae $\mathrm{n}$. sp.

12(7') Katatergite with white bristles. Front tibiae with long bristles, mostly white or black 13 
12' Katatergite with black bristles or mixed black and white. The long bristles on front tibiae mostly reddish- orange 14

13(12) Front tibiae with longer bristles mostly black. Hairs and bristles of scapo and pedicel, white. Hypandrium with a pair of reddish-brown apical spines, long and parallel on all its extension, these bristles are as long as gonopod and its apical process together. Gonopods with a short apical process, rounded and curved inward. Cerci slightly curved upward near the tip. Male genitalia as in Fig. 19B-19D, Ovipositor (Fig. 19E). Flagellomere (Fig. 19A)

magellanica (Artigas)

13' Front tibiae with bristles mostly yellowish-white. Scape and pedicel with hairs and bristles intermingled white and black. Hypandrium with two short spines, almost half the length of gonopod and process together. Cerci large, bend in middle and slightly recurved frontward (when genitalia is closed). Male genitalia (Fig. 25B and 25B-25C). Ovipositor (Fig. 25D). Flagellomere (Fig. 25A). Hind femora and tibiae as in Fig. 25E.

tregualemuensis $\mathrm{n} . \mathrm{sp}$.

14(2') Pedicel of flagellomere $1 / 4$ or $1 / 5$ the length of capitulum, similar to Fig. 10A. Cerci bend upward in middle in straight angle 15

14' Pedicel of flagellomere from $1 / 3$ the length of the capitulum to longer than it, similar to figs $12 \mathrm{~A}$ and $17 \mathrm{~A}$. Cerci large, recurved upward and frontward, or small, more or less straight, slightly curved upward at apex 16

15(14) Scutellar disc without hairs or bristles, only micropubescence. Front tibiae with long yellow bristles and long hairs, mostly white or light brown. Hind tibiae with reddish bristles. First tergite mostly with white bristles. Tergites vitreous blue, with shiny white sub triangular spots; in some females, tergites are shiny brown in color. Wings hyaline, without spots. Hypandrium blunt, slowly curved downward, without spines. Gonopods globular, short, with a rounded process directed backwards at apex. Male genitalia (Fig. 10B-10E). Ovipositor (Fig. 10F). Flagellomere (Fig. 10A). Argentina and Chile

critesi (Artigas)

15 Scutellar disc with black hairs. Front tibia with black bristles and hairs. Tergites shiny black, in part with bluish reflections and very fine golden micropubescence on dorsum, and white lines on posterior and costal margins of each tergite. Wings fumose brown with some week spots. Hypandrium pointed, curved downward in straight angle, with two parallel spines of moderate size. Gonopod with a long sinuous process directed backwards. Male genitalia (Fig. 13B and 13C). Ovipositor (Fig. 13D and 13E). Flagellomere (Fig. 13A) fucosa (Artigas)

16(14') Wings with few faint spots. Gonopod with distal process curved over the epandria, forming a kind of forceps, easily distinguishable from dorsal view; upper part of gonopod yellow, or at least of different color, or lighter than the remaining part of genitalia, contrasting with it (unique in genus). Male genitalia (Fig. 12B-12D). Ovipositor (Fig. 12E). Flagellomere (Fig. 12A)

digitata (Artigas)

16' Wings without or with well defined spots. Gonopod without the distal process indicated above, reddish-brown in color as remaining genitalia 17

17(16') Males with basal half of wing opaque milky white. (females unknown) 18

17' Males and females, with not clear difference in color on basal wing 19

18(17) Discoscutellar bristles and hairs, black. Front tibia with reddish integument. Tergites 4 to 7 similar in color and vestiture with preceding ones. Apical half of wing hyaline, without spots. Hypandrium more or less straight, does not reaches the apex of gonopods; no spines on apex. Gonopods 
slightly globular, with a sinuous process directed backward. Cerci small, curved in straight angle at apex. Male genitalia (Fig. 17B-17D). Flagellomere (Fig. 17A) (females unknown) leucoptera $\mathrm{n} . \mathrm{sp}$.

18' Scutellar disc devoided of bristles and hairs. Front tibiae with brown integument. Tergites 4 -7 slightly reddish. Apical half of wing fumose brown, with well define spots. Hypandrium longer or similar in length to gonopods, gently curved downward, with 2 parallel spines at the apex. Gonopods globular, short, with a short rounded apical process, directed toward the center. Cerci large, curved upwards and frontad. Male genitalia (Fig. 20F-20G). Flagellomere (Fig. 20E). Brasil obtusa (Engel)

19(17') Flagellomere as in Fig. 14A. Front tibiae with basal half or more, reddishbrown colored, black toward apex. Front tibia with the long hairs, black. Hypandrium without spines. Gonopod pointed, with a pre apical process, short and rounded, auricular in shape, directed centered and upwards. Male genitalia (Fig. 14B and 14C). Ovipositor (Fig. 14D and $14 \mathrm{E}$ ) fucosoides n. sp.

19' Flagellomere similar to Fig. 22A or 23A. Front tibia integument brown or reddish, with the long hairs, white. Hind tibiae with long, mostly white hairs. Hypandrium with 2 spines at apex. Gonopod with a sinuous apical process directed backwards 20

20(19') Sides of facial gibbosity shiny black or dull. Wings dull, slightly brownish in color, without spots or with faintly spots. Front tibiae with six parallel bristles on external face, in a comb like formation. Hind tibiae with 22 to 28 bristles. Gonopod with an apical, sub rectangular process, with the apex truncate and directed backwards. Hypandrium with 2 apical spines, slightly divergent. Cerci, from a posterior view longer than the spines of hypandrium. Body length 12 to $14 \mathrm{~mm}$. Male genitalia (Fig. 23B and C). Ovipositor (Fig. 23D). Flagellomere (Fig.
23A). Hind femur and tibia (Fig. 23E) ..... schineri (Artigas)

20' Sides of facial gibbosity with purple reflections. Wings hyaline, shiny, with well define spots. Anterior tibiae with 3 bristles on external side. Hind tibiae with 12 to 16 bristles. Gonopod with an apical process that narrows strongly to form a nipple directed backwards. Hypandrium with both spines parallel. Cerci, from a posterior view, shorter than the spines of hypandrium. Body length 8 to $10 \mathrm{~mm}$. Male genitalia (Fig. 22B-22D). Ovipositor (Fig. 22E and 22F). Flagellomere (Fig. 22A)

purpurea $\mathrm{n} . \mathrm{sp}$.

Tillobroma aconcaguana $n$. sp. (Fig. 7A-7F, 34A)

Holotype male, Allotype female: [Chile] Aconcagua, 7 agosto 90, Peña coll. Deposited in $\mathrm{Mu}$ seo de Zoología de la Universidad de Concepción (MZUC-UCCC).

Diagnosis: body and legs black. Legs and abdomen with abundant white hairs. Bristles of anterior and middle tibiae yellowish-white, on hind tibiae almost entirely black. On posterior margin of hind tibiae, there are extremely long hairs, some more than double the length of the basitarsus (Fig. 7E). This latter character is unique for this species in the genus. This species is easily distinguishable from other species of the genus by the black color of the body and legs and by the unusual length of the hind tibial hairs.

Holotype: head: sides of facial gibbosity shiny black, central area and sides with whitish micropubescence, bristles of mystax black with a few whites ones near the inferior border in the middle of oral border; scape and pedicel with white hairs and black bristles; flagellomere with the pedicel as long as the capitulum, both black (Fig. 7A); ocellar and frontal bristles long black, of similar length to upper bristles of mystax; postocular bristles black. Prothorax with white hairs. Mesonotum black, with golden brown micropubescence in the center of the anterior third; mesonotal bristles black, similar in length to the anterior and the postsuturals; $18-20$ bristles on scutellar border, center of scutellum without bristles, 
black, with weak whitish micropubescence; mesopleuron shiny black, with spots of whitish micropubescence; bristles on katatergite black. Wings slightly fuscate, and fumose, with dark brown veins, with diffuse spots at base of $\mathrm{r} 2, \mathrm{r} 4$ and $\mathrm{d}$, and in the veins $\mathrm{m}-\mathrm{r}$ and $\mathrm{CuA} 1$. Legs black; anterior and middle coxae with long brown hairs, white in hind coxae; femora with long white hairs; front tibiae with long black hair and five whitish yellow, thick spiny bristles, the longer ones as long as the basitarsus, arranged in line along external face of tibia, the remaining bristles are black and long; middle tibiae similar to the front ones; hind tibiae with white hairs and black bristles, along posterior face, are about 20 thick black elongate hairs, with a mean length of 2 to 2.5 times the length of the basitarsus, directed posteroventrally (Fig. 7E); tarsi with black bristles and black and white hairs. Abdomen shiny black, with gray micropubescence on lateral and posterior border of the last two tergites, micropubescence covers almost all the tergites; in all tergites there are abundant long hairs; sternites contains hairs, part are black and as long as the ones on the tergites. Genitalia rotated in $180^{\circ}$ (Fig. $7 \mathrm{~B}$ and C), all black with black bristles and fine white hairs; hypandrium with a spine projected posteriorly near base, and gently bent ventrally with two black, short spines at apex; gonopods globular at base with a distal projection directed inward and back, and then dorsad; epandria do not reach the distal part of hypandrium; cerci large, bent dorsally at straight angle.

Allotype female: Similar to the holotype. Ovipositor (Fig. 7D), shiny black, with black acanthophorites with 8 black spines. Tergites have less white hairs than male. Spermatheca (from a paratype) shown in Fig. 7F.

Measurements: total length: $11.0-13.5 \mathrm{~mm}$. Holotype: $12.0 \mathrm{~mm}$. Wing length: $8.5-9.0 \mathrm{~mm}$. Holotype: $9.0 \mathrm{~mm}$.

Material examined: 8 specimens: $10^{\circ}$ Holotype, 1 Allotype, $5 \uparrow$ and $1 \sigma^{\prime \prime}$ paratypes: [Chile], Aconcagua, 7 Agosto 90. Peña coll. (MZUC-UCCC).

Geographic distribution: according Fig. 34A.

Discussion: the specific name aconcaguana, is related with the patria tipica, Aconcagua. This species is easily distinguishable from other species of the genus by the black color of the body and legs and by the unusual length of the hind tibial hairs.

Tillobroma angulata $n$. sp. (Fig. $8 A-8 D, 8 F$, $27 F, 34 B$ )

Holotype: male, Invernada, Cordillera de Chillán, Provincia de Nuble [Chile], 5-12 octubre Coll. Ocare. Deposited in Museo de Zoología de la Universidad de Concepción (MZUC-UCCC).

Diagnosis: head and body shiny black, with few areas of golden micropubescence. Mystax black, dense and long, with few white hairs in the lower part. Tibiae with abundant golden hairs, long and fine, with few black bristles. Hind femora and tibiae with long, fine, erect hairs, mainly in ventral part of femur. Front tibiae with few bristles. Gonopods short, wide and globular, with an apical spurlike process, depressed at tip, directed inward at straight angle.

Holotype: head in frontal view: face and front black, facial gibbosity surrounded by golden micropubescence; frontal hairs black; few white hairs on postocular region. Head in side view: facial gibbosity black; antennae dark; first flagellomere claviform in distal half (Fig. 8A); first and second antennal segment with black hairs; mystax dense, almost with all black hairs, few white hairs on lower half intermingled with black hairs; bear white; proboscis with white hairs shorter on apex; maxillary palpi black with white hairs; postocular area black, with golden micropubescence and white hairs, more abundant on both sides of vertex. Prothorax black with fine white hairs, abundant on prothoracic lobes; thoracic pleuron with few areas of golden micropubescence; mesonotum and scutellum almost without micropubescence; central lines poorly defined; two black notopleuron bristles; two black intraalar bristles; 4 black scutellar bristles; mesepimeral bristles long and abundant. Wings hyaline with fuscosus veins, slightly lighter toward wing border. Coxa with golden micropubescence and white hairs, more abundant in frontal region of frontal coxa. Femur, tibia and tarsus black with limited black bristles intermingled with white bristles and abundant white fine hairs, intermingled with golden hairs; hind femur with a spine on 


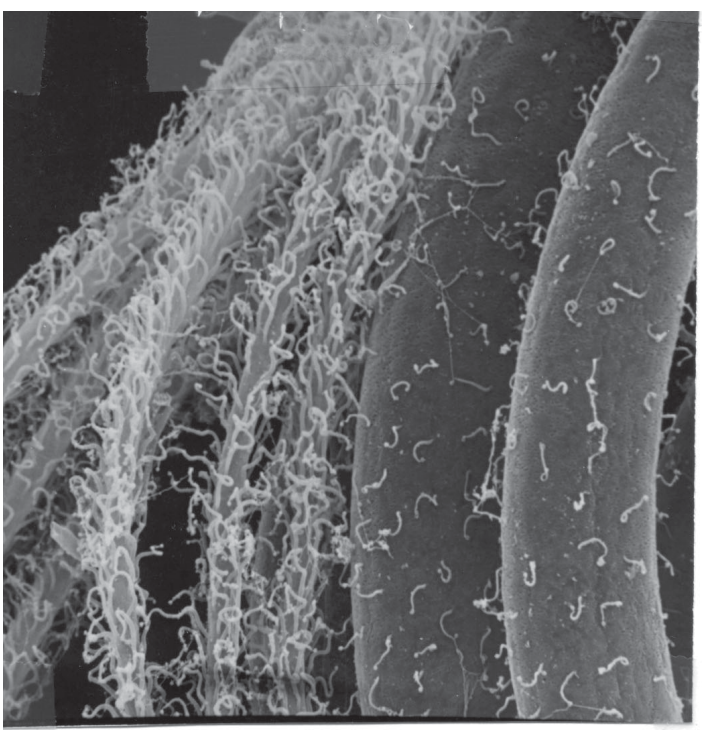

A

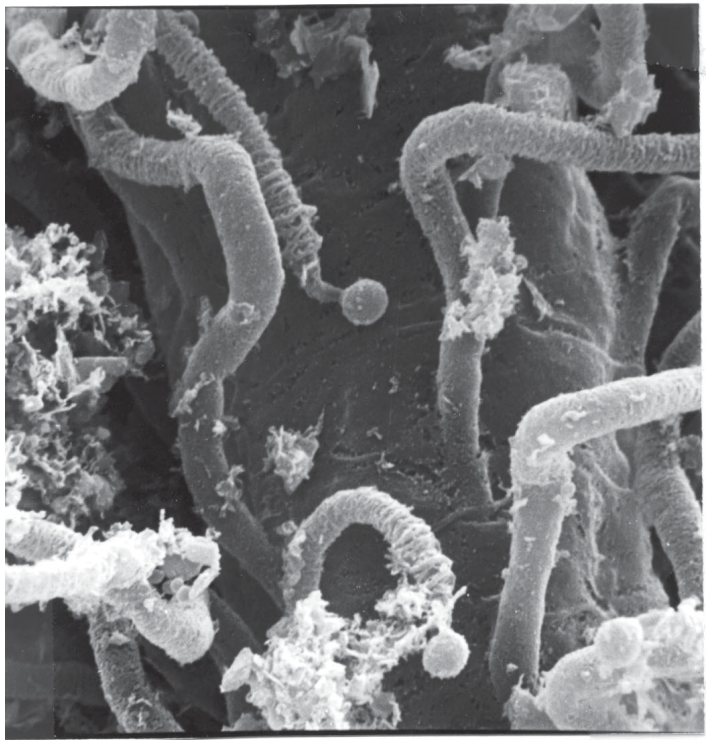

C
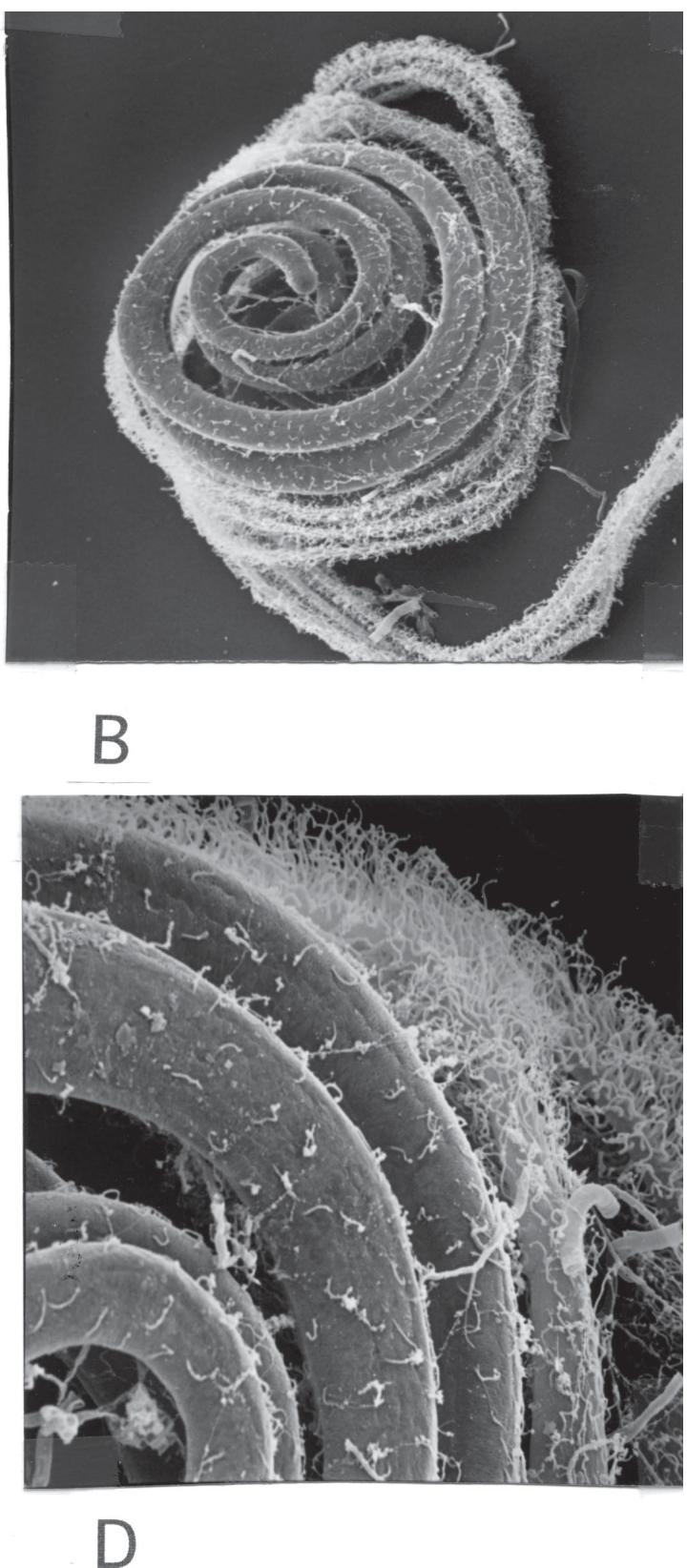

Fig. 6: Tillobroma schineri (Artigas). (A) Electronic photography of chitinous parts (KOH) of the spiracular capsule of the spermatheca, detail; (B) spiraled capsule; (C) canaliculi in detail, enlarged x 3000; (D) detail of inner part of the spiraled capsule showing position of canaliculi.

Tillobroma schineri (Artigas). (A) Microfotografía electrónica de las partes quitinosas (KOH) de la cápsula espiralada de la espermateca, detalle; (B) cápsula espiralada; (C) detalle de los canalículos aumentado x 3.000; (D) detalle del centro de la cápsula espiralada mostrando disposición de los canalículos. 


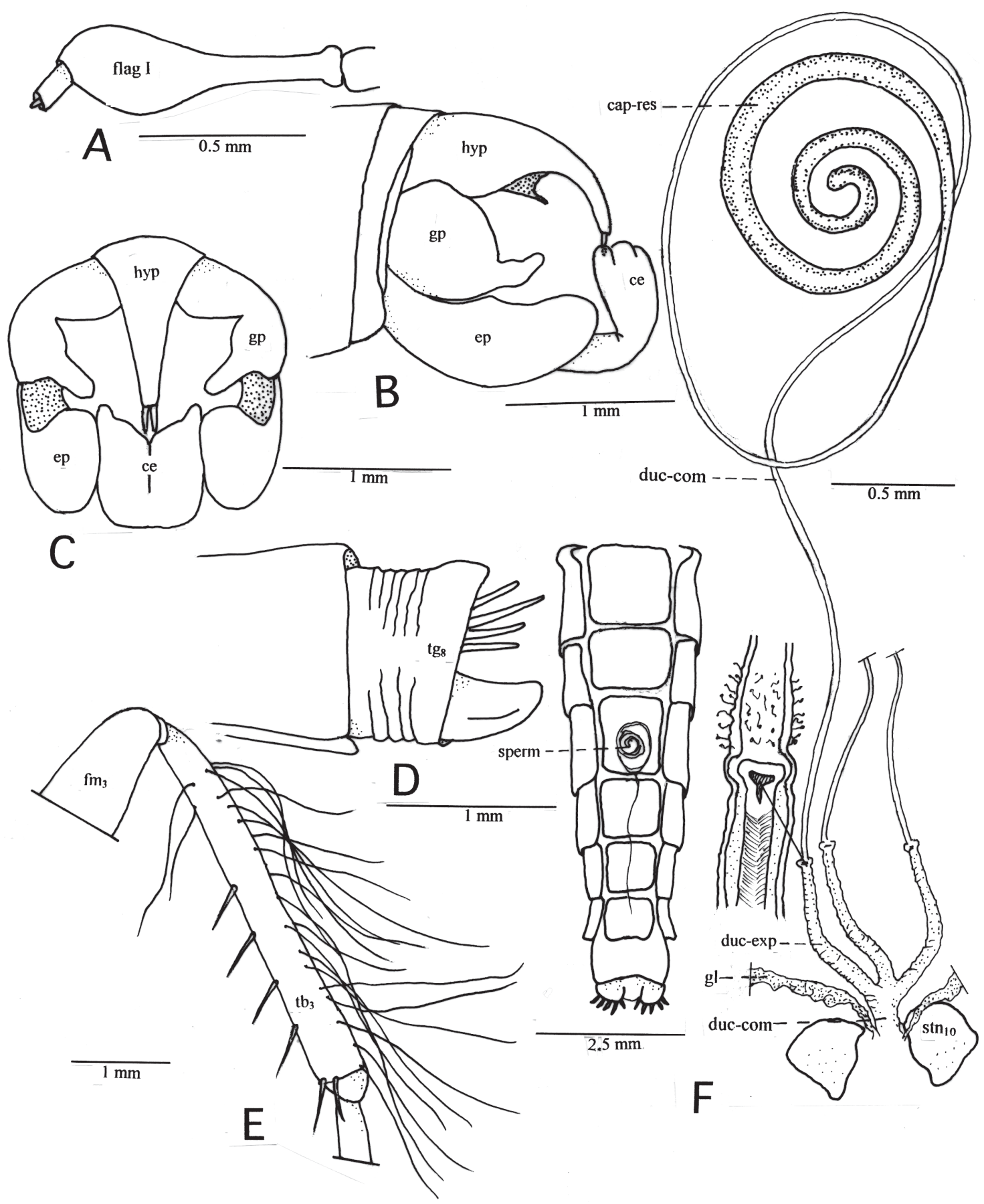

Fig. 7: Tillobroma aconcaguana n. sp. (holotype, allotype, except F). (A) Antenna in side view; (B) male genitalia in side view; (C) male genitalia from hind view; (D) ovipositor in side view; (E) hind tibia shows characteristic and extraordinary long hind hair; $(\mathrm{F})$ abdomen in ventral view, shows position of spermatheca; spermatheca $(\mathrm{KOH})$ and details.

Tillobroma aconcaguana n.sp. (holotipo, alotipo, excepto F). (A) Antena en vista lateral; (B) genitalia del macho en vista lateral; (C) genitalia del macho en vista posterior; (D) ovipositor en vista lateral; (E) tibia posterior señala característicos pelos posteriores extraordinariamente largos; (F) abdomen en vista ventral, muestra posición de la espermateca; espermateca $(\mathrm{KOH})$ y detalles. 

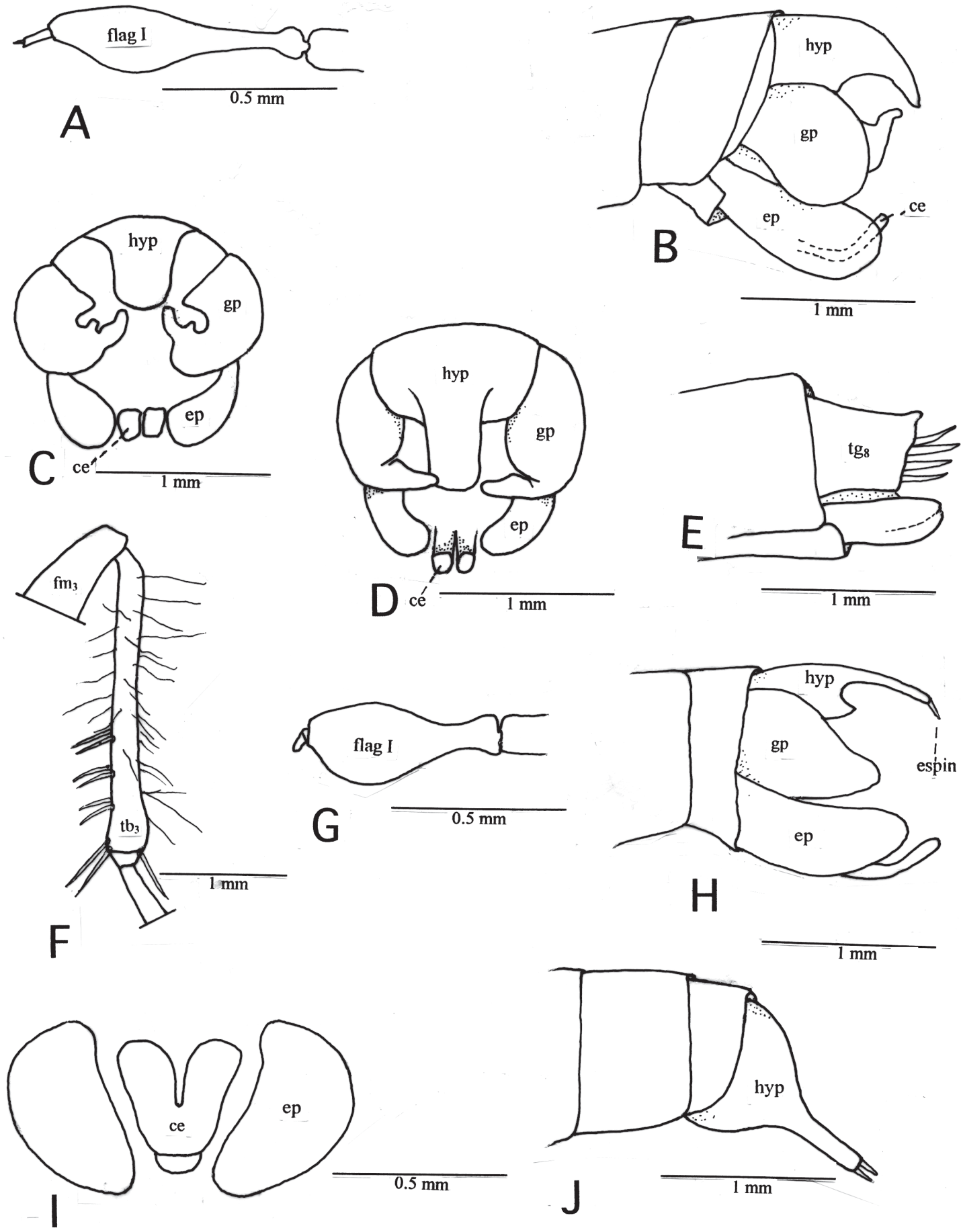

Fig. 8: Tillobroma angulata n. sp. (holotype, except E). (A) Antenna in side view; (B) male genitalia in side view; (C) male genitalia from hind view; (D) male genitalia in dorsal view; (E) ovipositor in side view; (F) hind tibia. Tillobroma asiliformis (Wulp) (neotype). (G) Antenna in side view; (H) male genitalia in side view; (I) scheme of male genitalia in hind view; cerci are shown; (J) male end in dorsal view, shows twisting.

Tillobroma angulata n. sp. (holotipo excepto E). (A) Antena vista lateral; (B) genitalia del macho vista lateral; (C) genitalia del macho vista posterior; (D) genitalia del macho vista dorsal; (E) ovipositor vista lateral; (F) tibia posterior. Tillobroma asiliformis (Wulp) (neotipo). (G) Antena vista lateral; (H) genitalia del macho vista lateral; (I) esquema genitalia del macho vista posterior, destacan los cercos; (J) terminalia del macho vista dorsal, muestra torsión. 


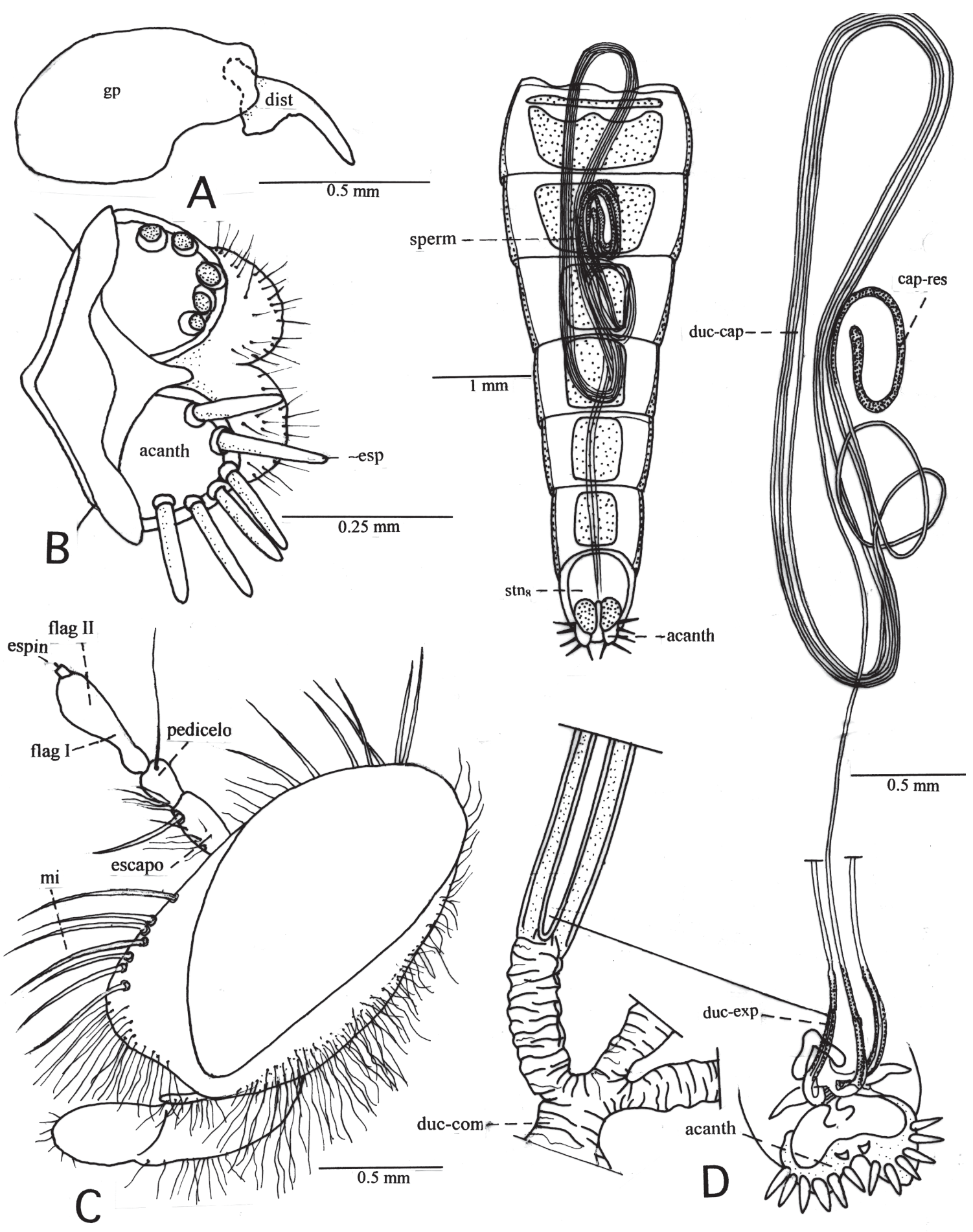

Fig. 9: Tillobroma asiliformis (Wulp) (neotype, except B and D). (A) Gonopods and dististylus in side view; (B) acanthophorites (KOH) in ventral view; (C) head in side view; (D) abdomen in ventral view, shows position of spermatheca; spermatheca $(\mathrm{KOH})$ and details.

Tillobroma asiliformis (Wulp) (neotipo excepto B y D). (A) Gonopodo y dististilo vista lateral; (B) acantoforitos (KOH) vista ventral; (C) cabeza vista lateral; (D) abdomen vista ventral, muestra posición de la espermateca; espermateca (KOH) y detalles. 

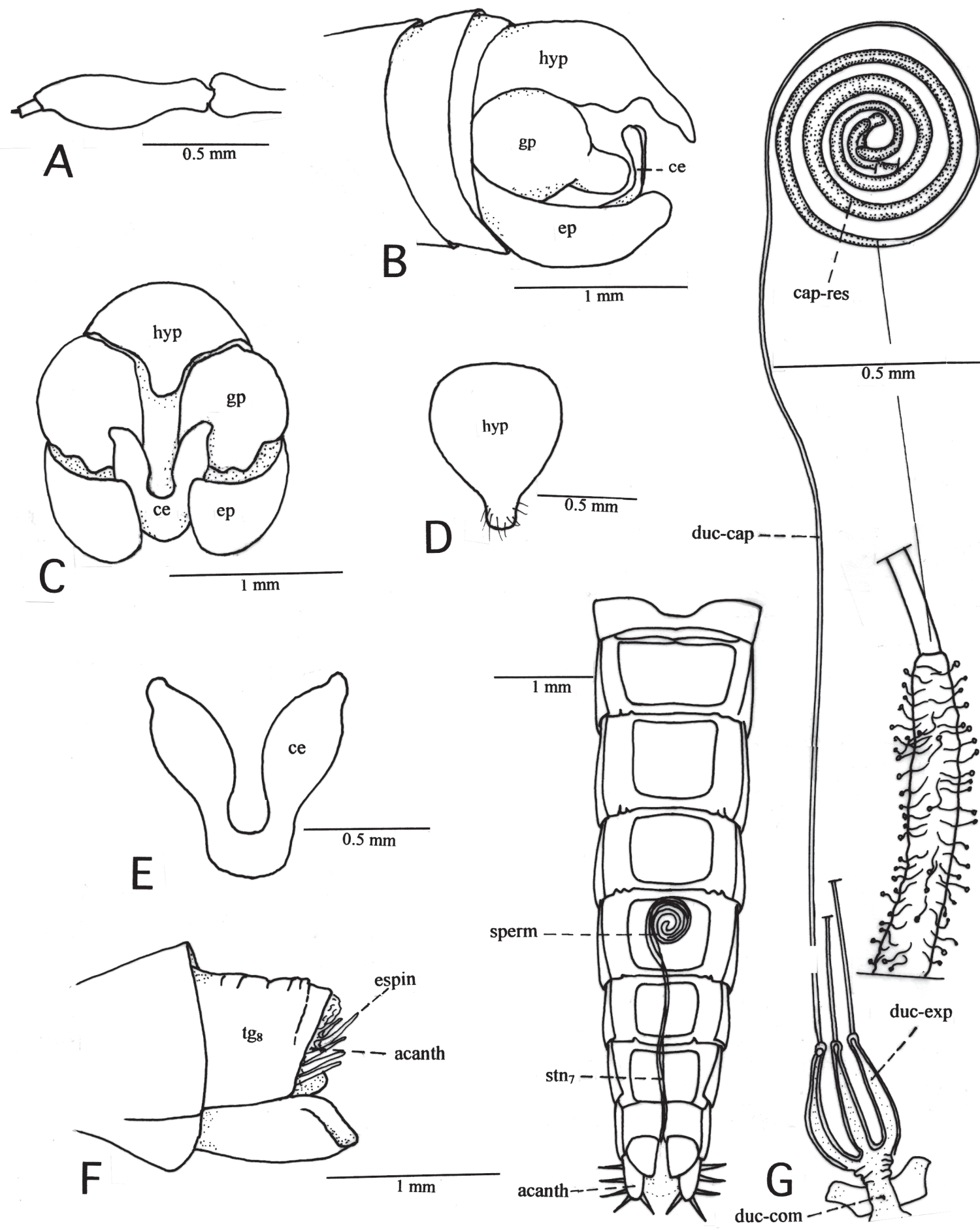

Fig. 10: Tillobroma critesi (Artigas) (holotype, allotype, except G). (A) Antenna in side view; (B) male genitalia in side view; (C) male genitalia from hind view; (D) hypandrium in dorsal view; (E) cerci in hind view; (F) ovipositor; (G) abdomen in ventral view, shows position of the spermatheca; spermatheca $(\mathrm{KOH})$ and details.

Tillobroma critesi (Artigas) (holotipo, alotipo, excepto G). (A) Antena vista lateral; (B) genitalia del macho vista lateral; (C) genitalia del macho vista posterior; (D) hipandrio vista dorsal; (E) cercos vista posterior; (F) ovipositor; (G) abdomen vista ventral, muestra posición de la espermateca; espermateca $(\mathrm{KOH})$ y detalles. 


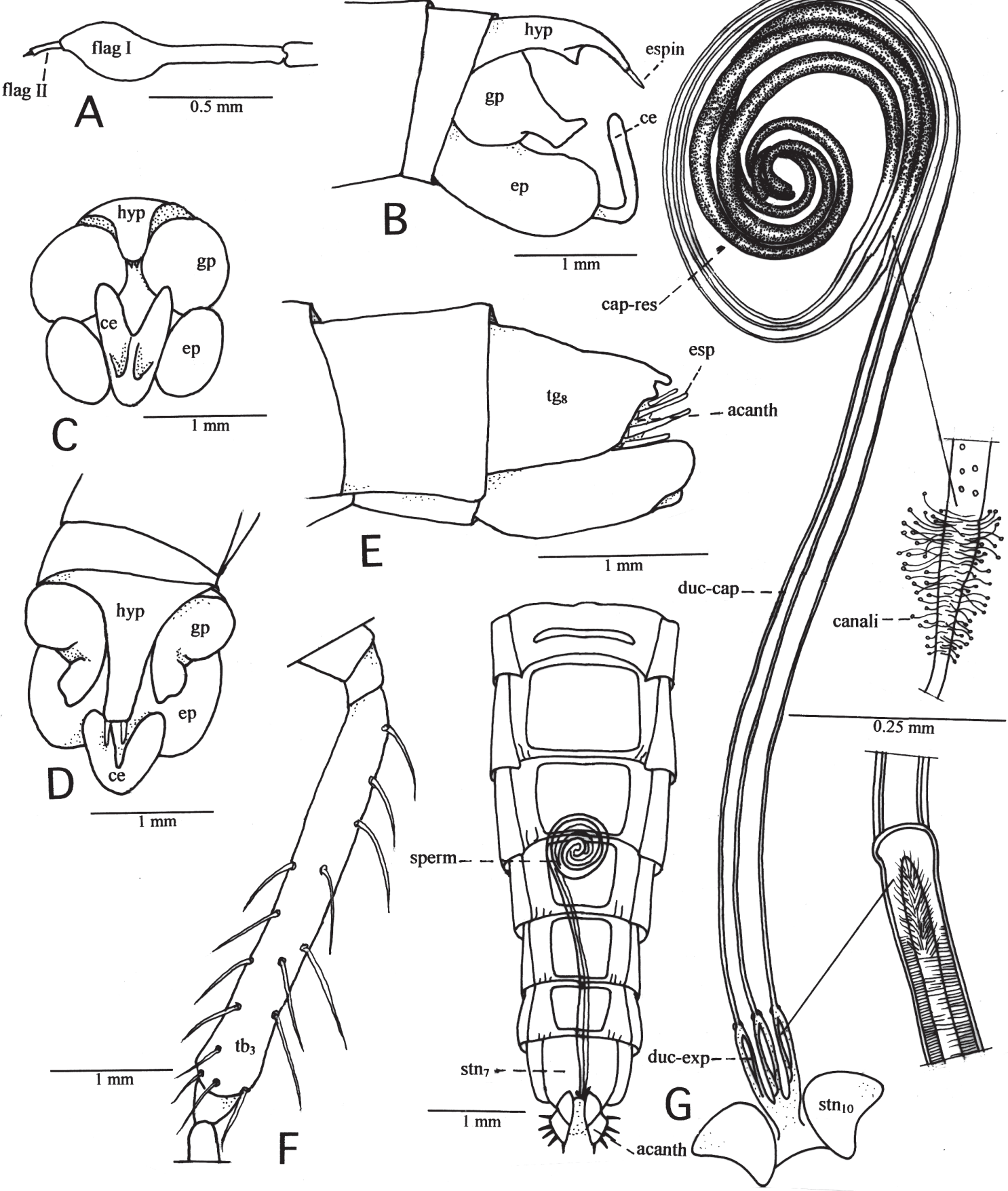

Fig. 11: Tillobroma davidsoni (Artigas) (holotype, allotype, except F). (A) Antenna in side view; (B) male genitalia in side view; (C) male genitalia from hind view; (D) male genitalia in dorsal view; (E) ovipositor in side view; (F) hind tibia; (G) abdomen in ventral view, shows position of spermatheca; spermatheca and details.

Tillobroma davidsoni (Artigas) (holotipo, alotipo, excepto. F). (A) Antena vista lateral; (B) genitalia del macho vista lateral; (C) genitalia del macho vista posterior; (D) genitalia del macho vista dorsal; (E) ovipositor vista lateral; (F) tibia posterior; $(\mathrm{G})$ abdomen vista ventral, muestra posición de espermateca; espermateca y detalles. 

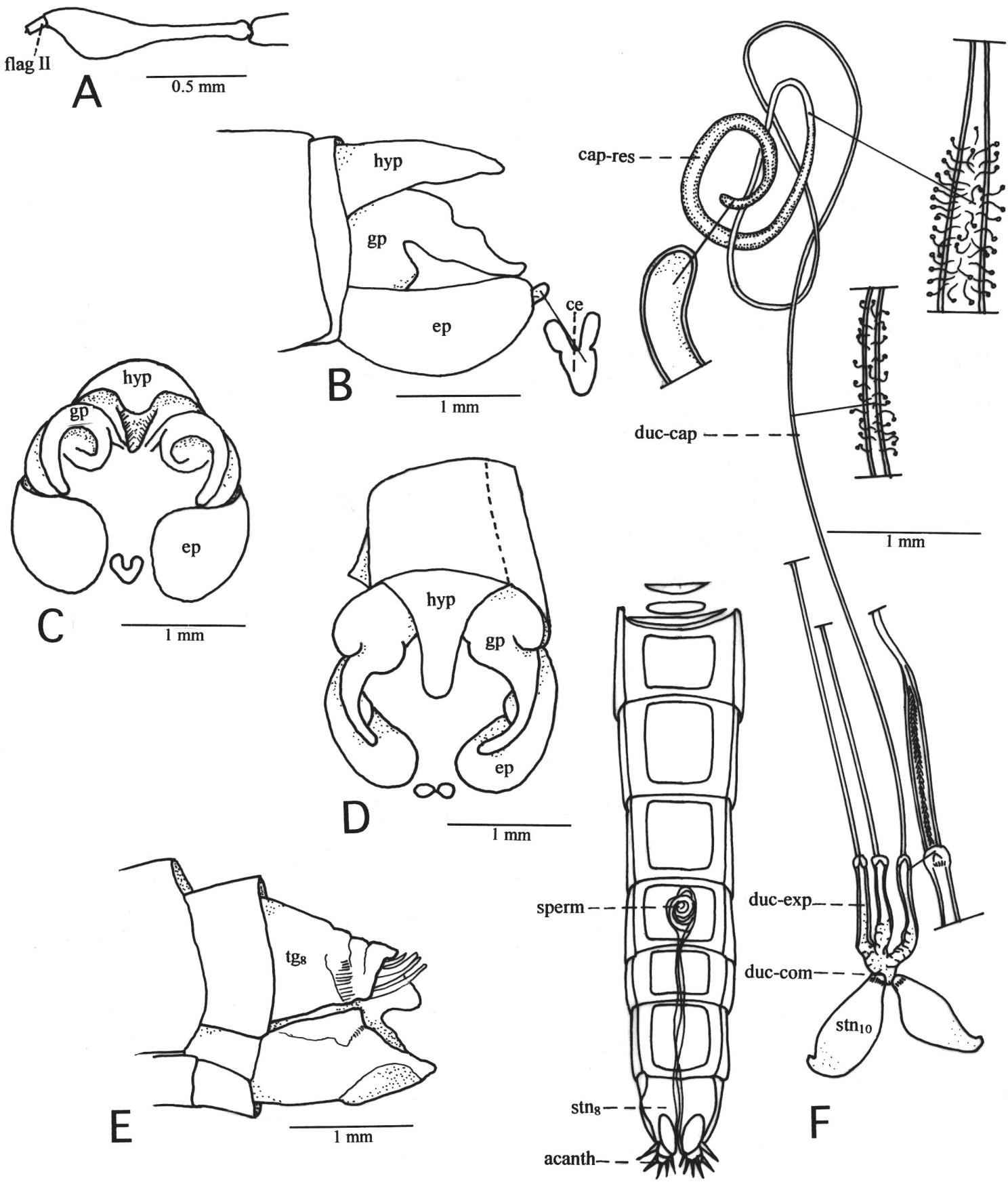

Fig. 12: Tillobroma digitata (Artigas) (holotype, allotype, except E and F). (A) Antenna in side view; (B) male genitalia in side view; (C) male genitalia from hind view; (D) male genitalia in dorsal view; (E) ovipositor in side view; (F) abdomen in ventral view, shows position of spermatheca; spermatheca and details.

Tillobroma digitata (Artigas) (holotipo, alotipo, excepto E y F). (A) Antena vista lateral; (B) genitalia del macho vista lateral; (C) genitalia del macho en vista posterior; (D) genitalia del macho vista dorsal; (E) ovipositor vista lateral; (F) abdomen vista ventral, muestra posición de espermateca; espermateca y detalles. 


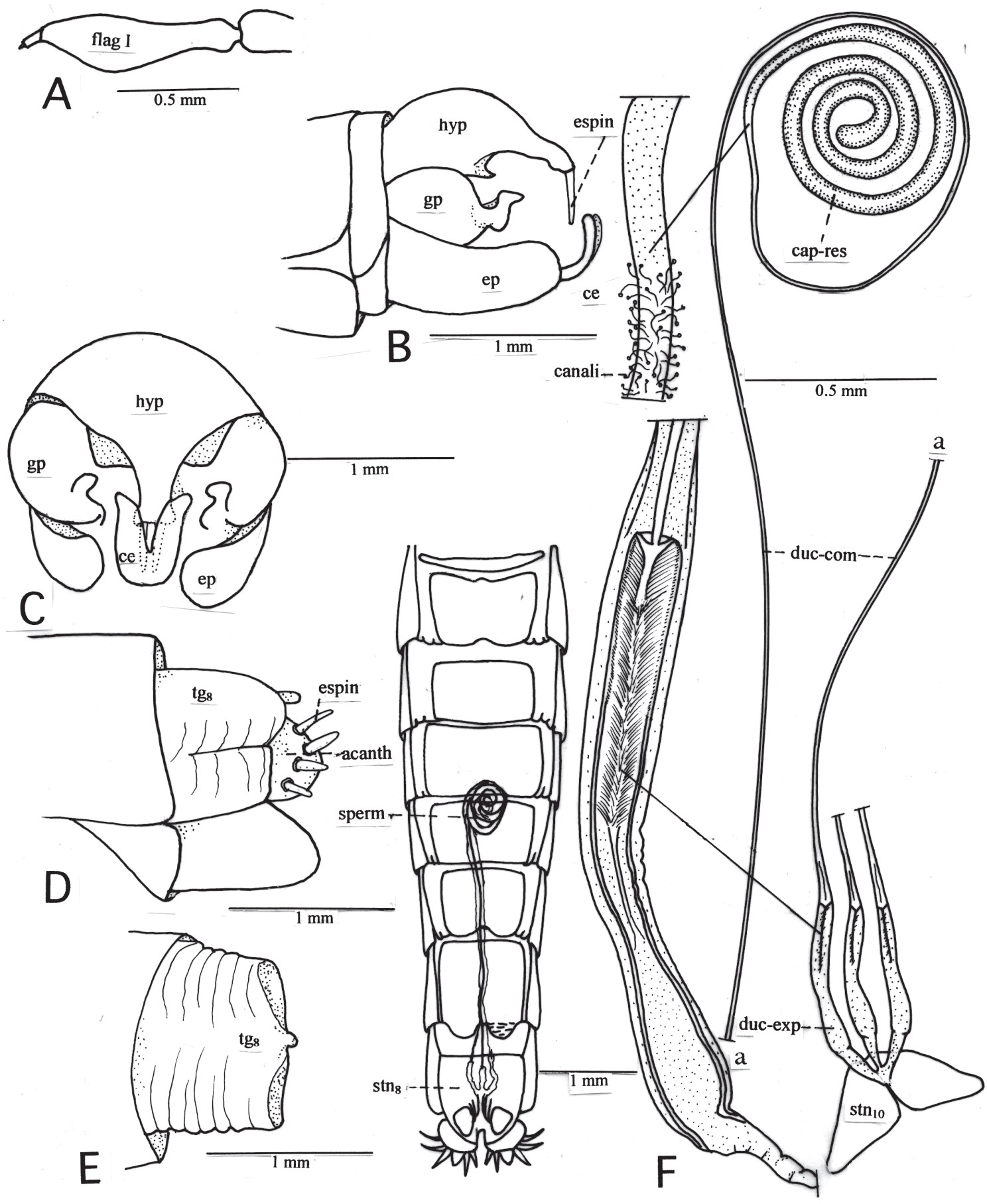

Fig. 13: Tillobroma fucosa (Artigas) (holotype, allotype, except D-F). (A) Antenna in side view; (B) male genitalia in side view; (C) male genitalia from hind view; (D) ovipositor in side view; (E) ovipositor in dorsal view; (F) abdomen in ventral view, shows position of the spermatheca; spermatheca and details.

Tillobroma fucosa (Artigas) (holotipo, alotipo, excepto D-F). (A) Antena en vista lateral; (B) genitalia del macho vista lateral; (C) genitalia del macho en vista posterior; (D) ovipositor vista lateral; (E) ovipositor vista dorsal; (F) abdomen vista ventral, muestra posición de la espermateca; espermateca y detalles. 

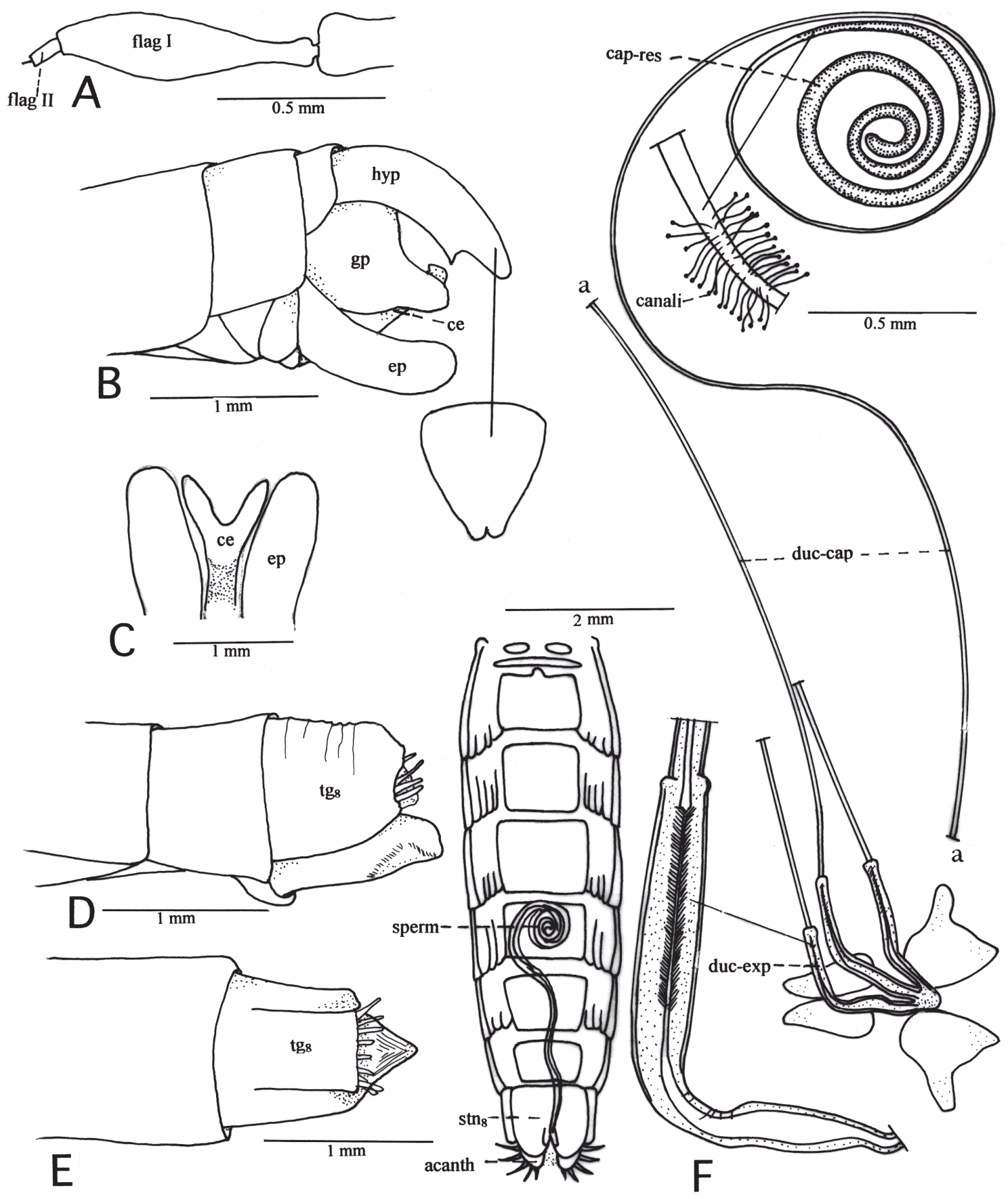

Fig. 14: Tillobroma fucosoides n. sp. (holotype, allotype, except F: paratype). (A) Antenna in side view; (B) male genitalia in side view; (C) gonopods and cerci in hind view; (D) ovipositor in side view; (E) ovipositor in dorsal view; (F) abdomen in ventral view, shows position of spermatheca; spermatheca and details.

Tillobroma fucosoides n. sp. (holotipo, alotipo, excepto F: paratipo). (A) Antena vista lateral; (B) genitalia del macho vista lateral; (C) gonopodos y cercos en vista posterior; (D) ovipositor vista lateral; (E) ovipositor vista dorsal; (F) abdomen vista ventral, muestra posición de espermateca; espermateca y detalles. 


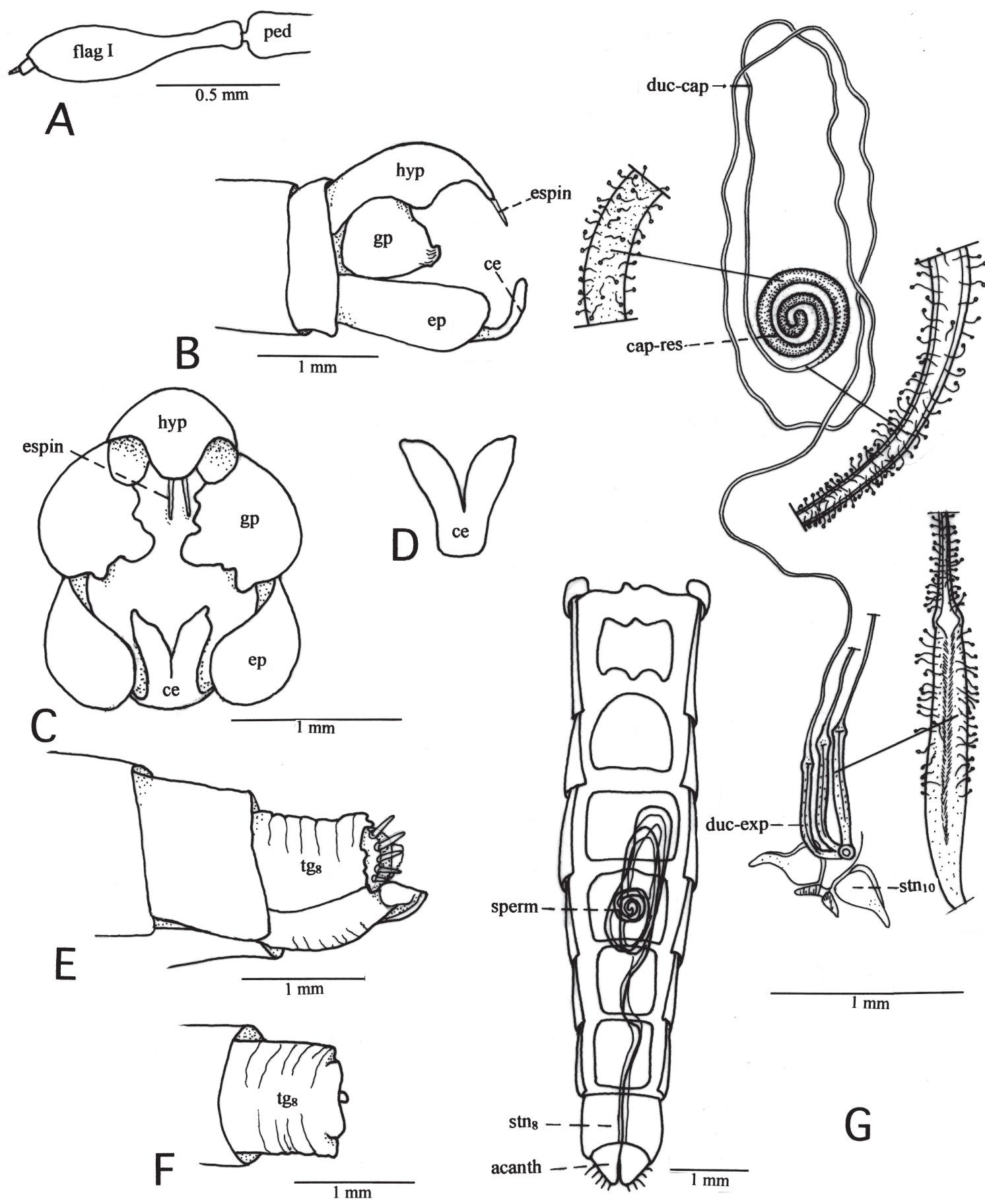

Fig. 15: Tillobroma fulvicornis (Macquart) (neotype, except E-G). (A) Antenna in side view; (B) male genitalia in side view; (C) male genitalia from hind view; (D) cerci in hind view; (E) ovipositor in side view; (F) ovipositor in dorsal view; (G) abdomen in ventral view, shows position of spermatheca; spermatheca and details.

Tillobroma fulvicornis (Macquart) (neotipo, excepto E-G). (A) Antena vista lateral; (B) genitalia del macho en vista lateral; (C) genitalia del macho en vista posterior; (D) cercos en vista posterior; (E) ovipositor en vista lateral; (F) ovipositor vista dorsal; (G) abdomen vista ventral, muestra posición de espermateca; espermateca y detalles. 


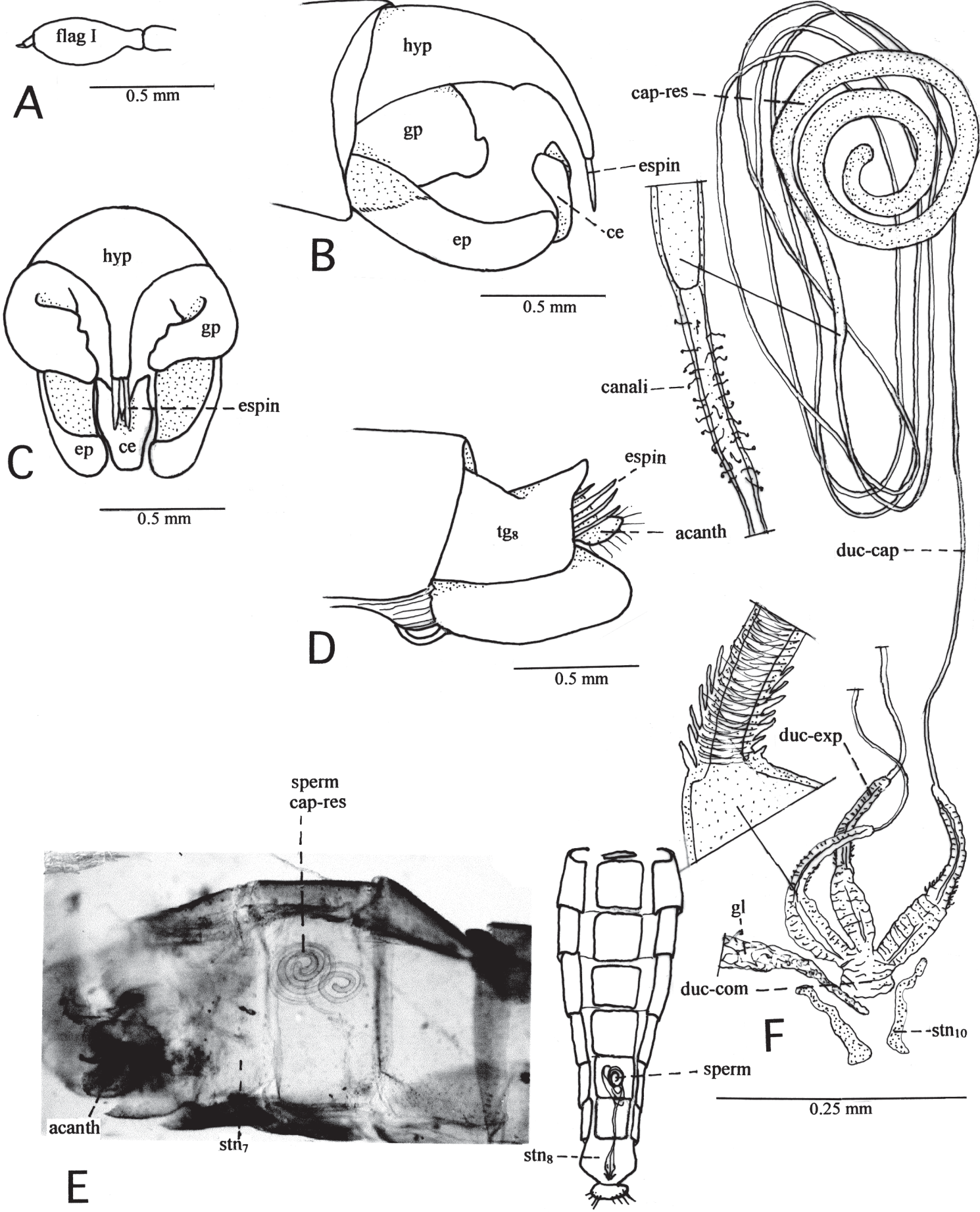

Fig. 16: Tillobroma huasquina n. sp. (holotype, allotype, except E and F). (A) Antenna in side view; (B) male genitalia in side view; (C) male genitalia from hind view; (D) ovipositor in side view; (E) microphotography of abdomen in ventral view, shows position of the spermatheca; (F) abdomen in ventral view, shows position of spermatheca; spermatheca and details.

Tillobroma huasquina n. sp. (holotipo, alotipo, excepto E y F). (A) Antena en vista lateral; (B) genitalia del macho vista lateral; (C) genitalia del macho en vista posterior; (D) ovipositor vista lateral; (E) microfotografía del abdomen en vista ventral, muestra posición de la espermateca; (F) abdomen en vista ventral, muestra ubicación de espermateca; espermateca y detalles. 

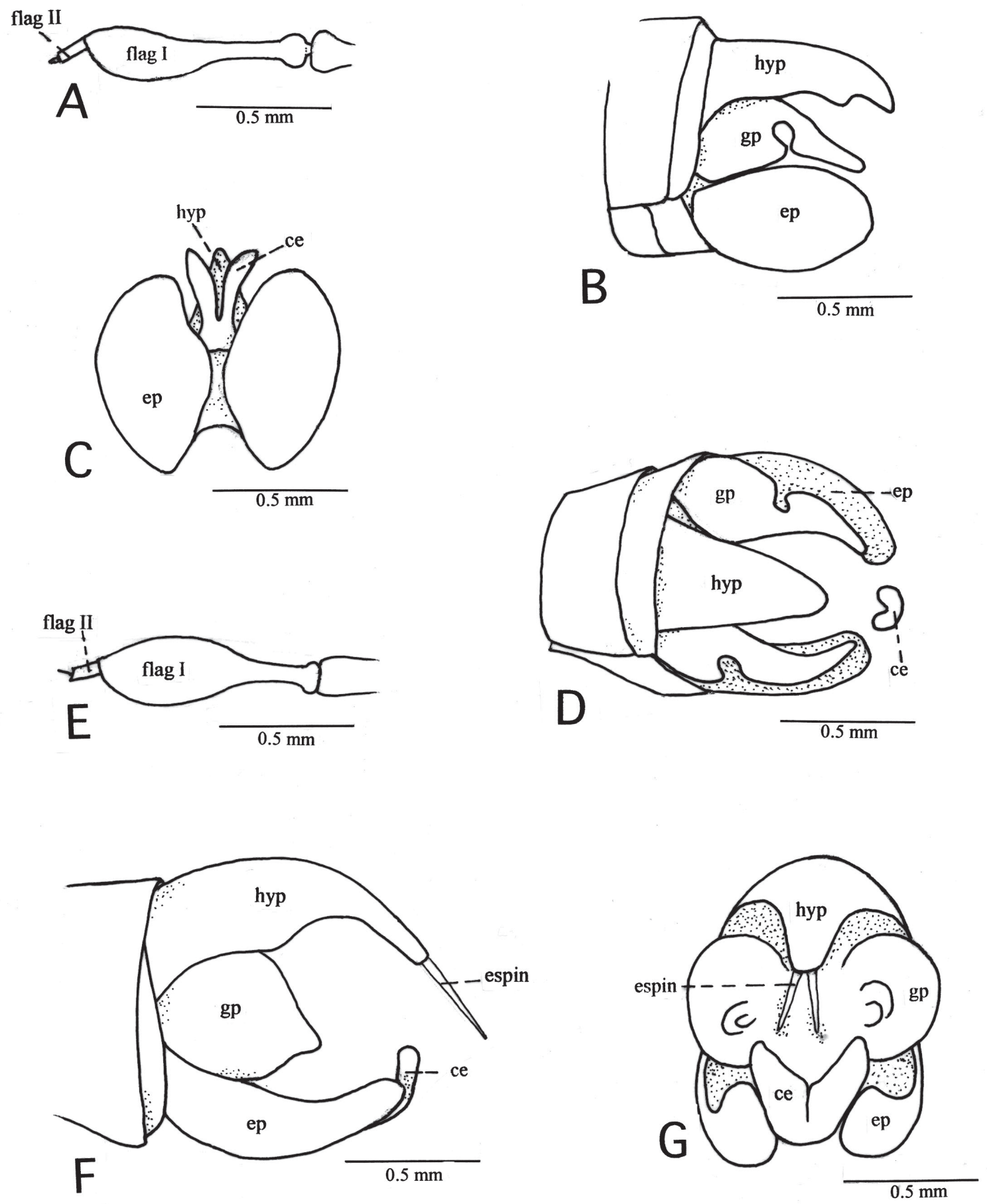

Fig. 17: Tillobroma leucoptera n. sp. (holotype). (A) Antenna in side view; (B) male genitalia in side view; (C) male genitalia from hind view; (D) male genitalia from dorsal view.

Tillobroma leucotrica n. sp. (holotype). (E) Antenna in side view; (F) male genitalia in side view; (G) male genitalia from hind view.

Tillobroma leucoptera $\mathrm{n}$. sp. (holotipo). (A) Antena en vista lateral; (B) genitalia del macho en vista lateral; (C) genitalia del macho en vista posterior; (D) genitalia del macho en vista dorsal.

Tillobroma leucotrica n. sp. (holotipo). (E) Antena en vista lateral; (F) genitalia del macho en vista lateral; (G) genitalia del macho en vista posterior. 

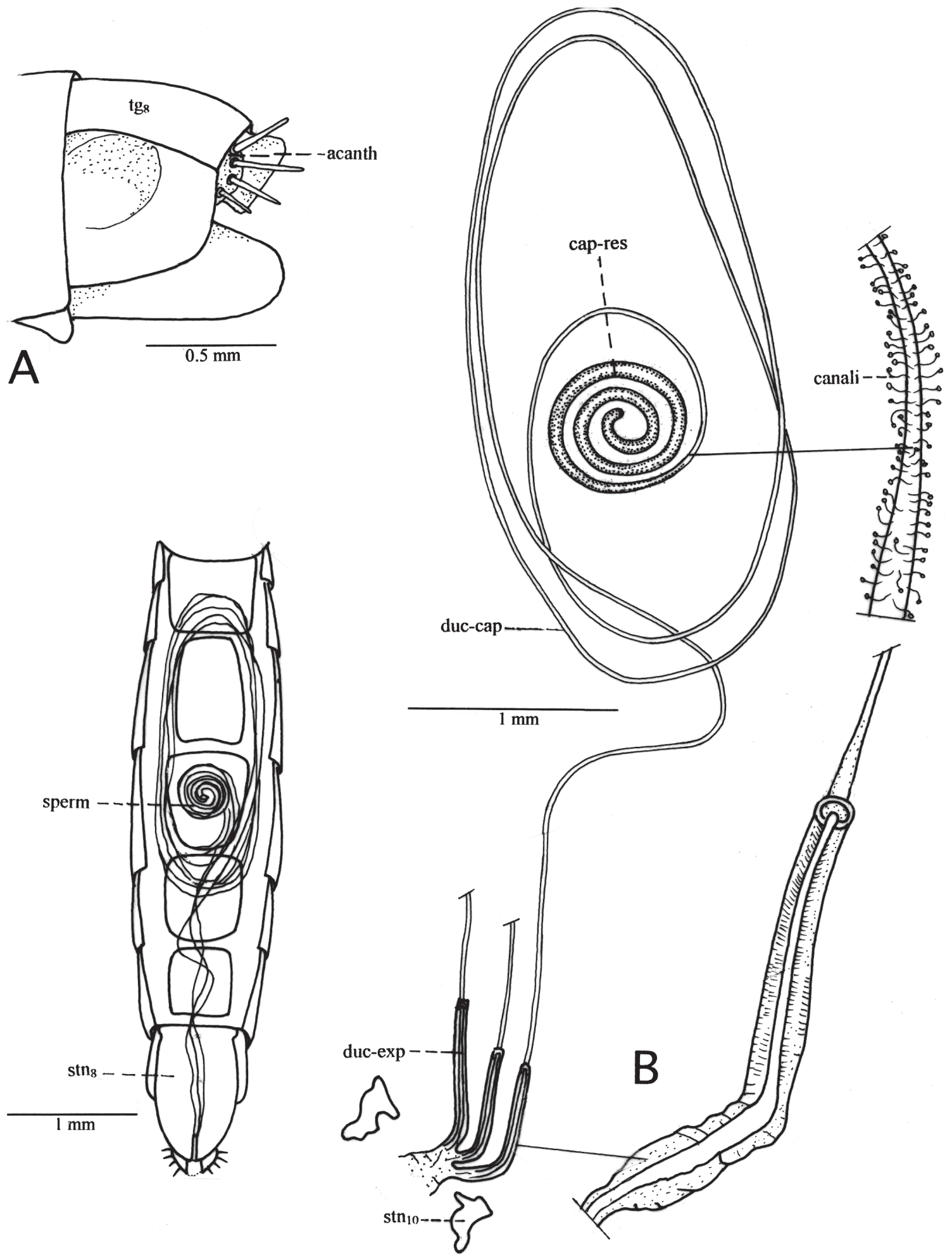

Fig. 18: Tillobroma leucotrica n. sp. (A) Ovipositor in side view (allotype); (B) abdomen in ventral view, shows position of spermatheca; spermatheca and details (paratype).

Tillobroma leucotrica n. sp. (A) Ovipositor en vista lateral (alotipo); (B) abdomen en vista ventral, muestra posición de espermateca; espermateca y detalles (paratipo). 

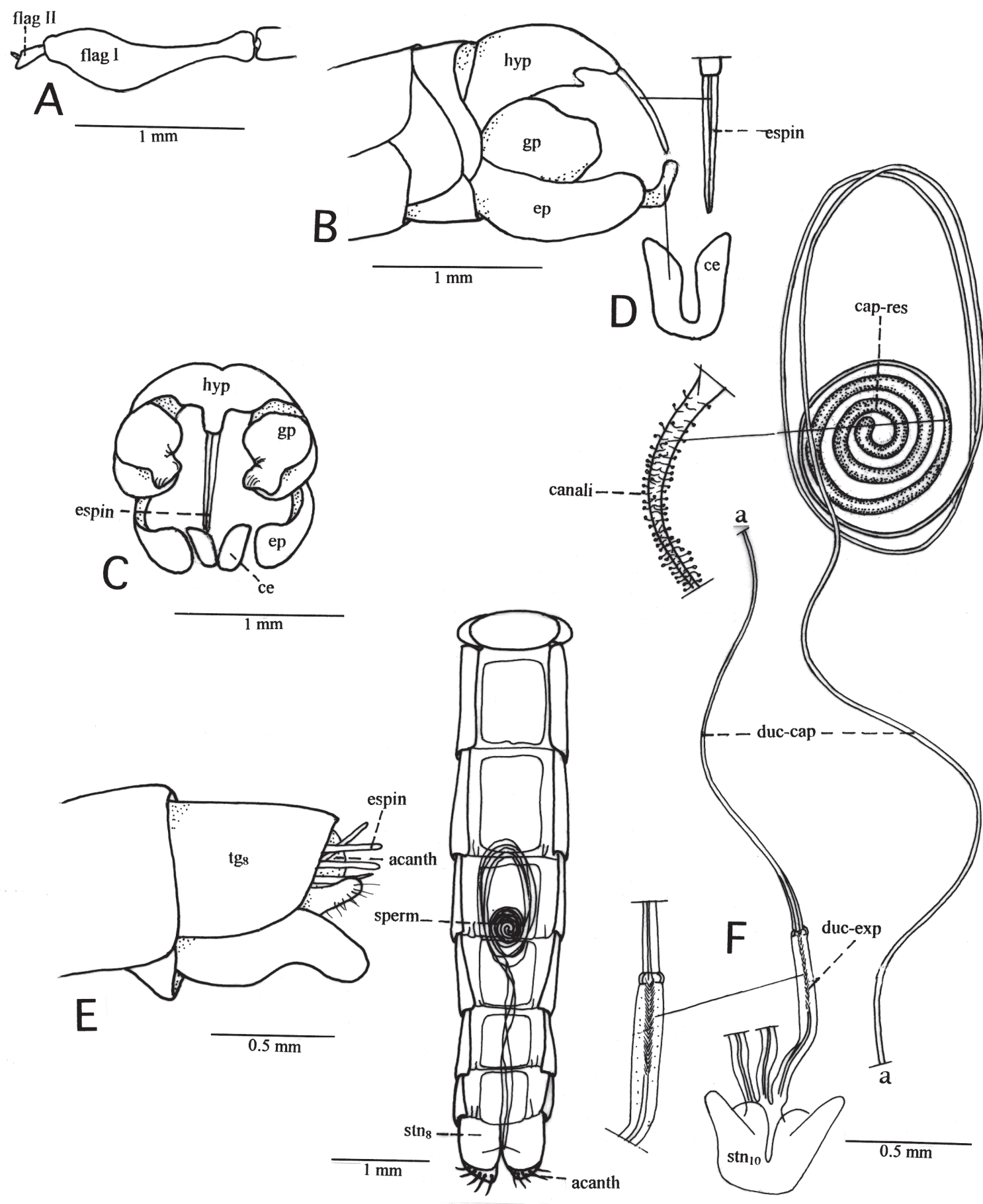

Fig. 19: Tillobroma magellanica (Artigas) (holotype, allotype, except F: paratype). (A) Antenna in side view; (B) male genitalia in side view; apical spines of hypandrium from hind view; (C) male genitalia from hind view; (D) cerci in hind view; (E) ovipositor in side view; (F) abdomen in ventral view, shows position of spermatheca; spermatheca and details.

Tillobroma magellanica (Artigas) (holotipo, alotipo, excepto F: paratipo). (A) Antena en vista lateral; (B) genitalia del macho en vista lateral; espinas apicales del hipandrio en vista posterior; (C) genitalia del macho en vista posterior; (D) cercos en vista posterior; (E) ovipositor en vista lateral; (F) abdomen en vista ventral, muestra posición de espermateca; espermateca y detalles. 

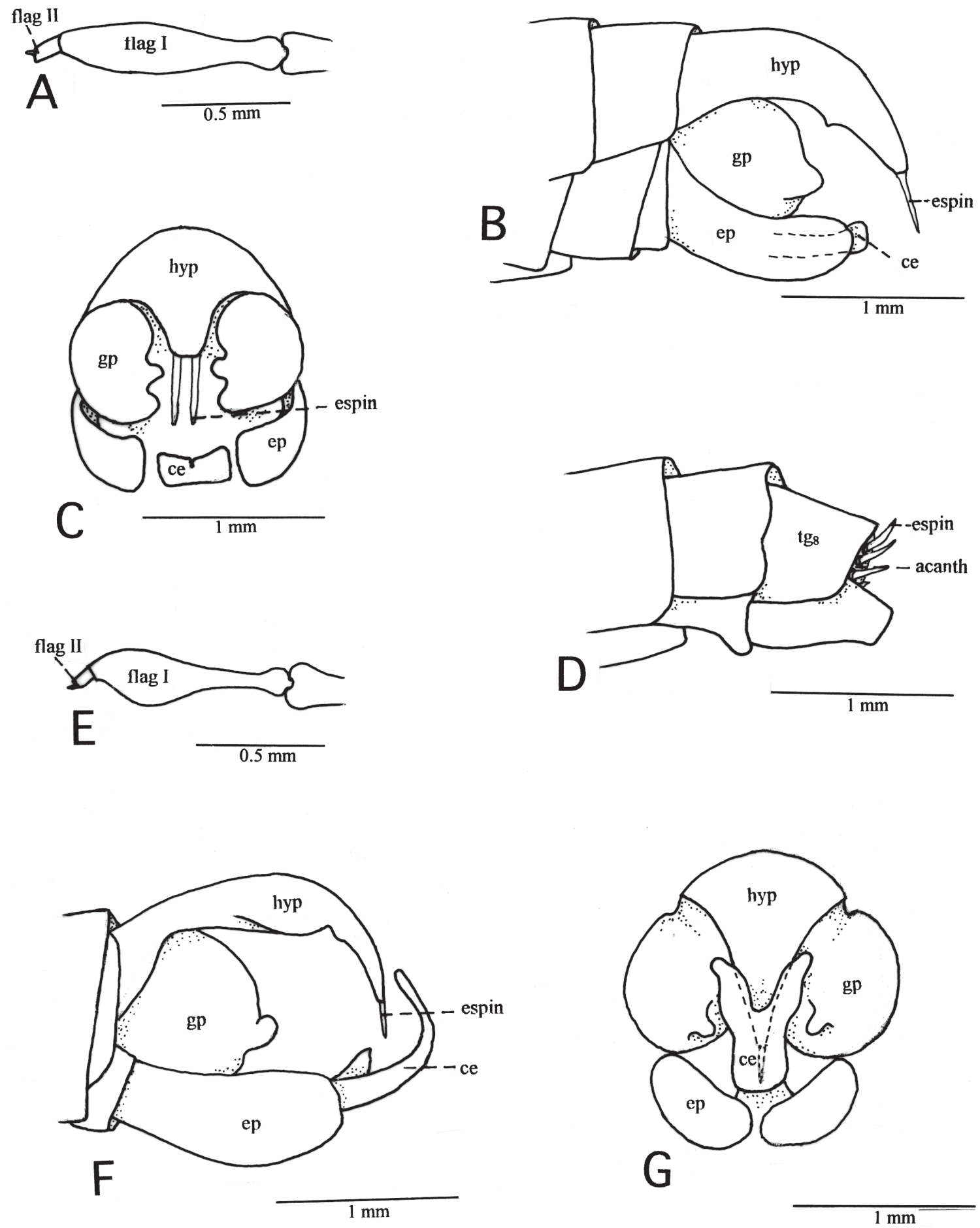

Fig. 20: Tillobroma nahuelbutae n. sp. (holotype, allotype). (A) Antenna in side view; (B) male genitalia in side view; (C) male genitalia from hind view; (D) ovipositor in side view.

Tillobroma obtusa (Engel). (E) Antenna in side view; (F) male genitalia in side view; (G) male genitalia from hind view.

Tillobroma nahuelbutae n. sp. (holotipo, alotipo). (A) Antena en vista lateral: (B) genitalia del macho en vista lateral; (C) genitalia del macho en vista posterior; (D) ovipositor en vista lateral.

Tillobroma obtusa (Engel). (E) Antena en vista lateral; (F) genitalia del macho en vista lateral; (G) genitalia del macho en vista posterior. 
external side, near apex. Abdomen black, with areas of golden micropubescence on lateral border of tergites; abundant white hairs all over the abdomen; first tergite with abundant long white hairs, remarkable on sides, and directed backwards on apical half of abdomen. Genitalia (Fig. 8B-8D), fuscate, with areas of unequal intensity; long hairs on hypandrial apex, longer than the ones on epandrium; hypandrium gently curved toward distal region, without spine on apex; gonopod globular, almost as long as wide, with an apical flattened process, directed inward at straight angle, almost reaching tip of hypandrium (Fig. 8B and 8C). Aedeagus (from a paratype), as in Fig. 27F.

Female: unknown.

Material examined: five specimens: $2 \sigma^{\prime \prime}(1$ holotype), Invernada, Cordillera de Chillán, Provincia de Nuble [Chile], 5/12-octubre 1970, Coll. Ocare: three $\sigma^{*}$, Invernada, Cordillera Chillán, Provincia de Ñuble, Septiembre 1970, Coll. Ocare. This material has been deposited in the Museo de Zoología de la Universidad de Concepción (MZUC-UCCC).

Geographic distribution: as in Fig. 34B.

Discussion: this species can be recognized for the irregular coloration of the male genitalia, lighter areas contrasting with the remaining areas, and for the apical process of the gonopods which are directed in straight angle to the center.

The name angulata refers to the inward direction of the apical process of gonopod.

Tillobroma asiliformis (Wulp) (Fig. 8E, 8G-9D, 26E, 30D)

Hypenetes asiliformis Wulp, 1882: 101. Argentina; Bromley, 1932: 264, Argentina; Hull, 1962, neotropical: 154; Artigas, 1970:124, Chile. Tillobroma asiliformis (Wulp). Artigas \& Papavero, 1991: 26, n. comb.

Type: male, Argentina (Weyenbergh), locality unknown. Deposit unknown. A neotype is here designated.

Neotype: male, Lag. [Laguna] Amarga, Natales. E of Mt. Payne. $200 \mathrm{~m}$ Magallanes, Chile, 14-20 XII. 60. Pena. Deposited in Museo de Zoología de la Universidad de Concepción (MZUC-UCCC).

Diagnosis: head and body with abundant gray and golden micropubescence, dispersed in poorly defined areas. Mystax with dark brown thick bristles in upper half, fine white bristles on lower half, latter more dense than the upper ones. Legs with short fusiform hairs depressed against the integument. Bristles of notum, scutellum, laterad of first abdominal tergite, ocellus and front, same color of the upper bristles of mystax; remaining bristles and hairs of body and legs, white.

Neotype: head in frontal view (Fig. 9C): face and front covered by dense silver micropubescence, slightly golden on face; most of the frontal hairs white; ocellar bristles dark brown. Head in lateral view: facial gibbosity dark gray; mystax formed by thick dark brown bristles on upper half and fine white hairs on lower part; antennae (Fig. 8G), black with white hairs; beard white; occipital and postocular vestiture white; proboscis and maxillary palpus black, with white pilosity. Prothorax with abundant golden micropubescence and few white dispersed hairs. Thoracic pleuron with large areas of golden micropubescence and few white hairs; mesepimeron with abundant white bristles. Mesonotum with golden micropubescence, more or less uniform; central lines well defined; lateral spots brown, vestiture of white, dispersed, thick hairs; scutellum similar in color and vestiture to mesonotum; six dorsocentral bristles; two notopleural bristles; one intra-alar bristle; two postalar bristles and three scutellar bristles, all dark brown in color. Anatergite with yellow micropubescence. Katatergite with white bristles. Wing hyaline, without spots, with dark venation. Vestiture on caxa similar to the one in thoracic pleuron, more abundant on anterior part of coxae; femora black; tibiae and tarsi reddish. Legs densely covered by white, fusiform hairs, flattened against the integument and light bristles on tarsus and tibia. Abdomen with gray micropubescence; sides of tergites black; vestiture of scarce fine, white hairs. Male genitalia (Fig. 8H - 9A) black, with abundant depressed white hairs; two spines at apex of the hypandrium: aedeagus (from other specimen) as in Fig. 27E.

Female: similar to male. Ovipositor with spines of acanthophorite black (Fig. 9B). Spermatheca as in Fig. 9D.

Measurements: total length: 7.0-9.0 $\mathrm{mm}$. Neotype: $8.7 \mathrm{~mm}$. Wing length: 5.6-5.9 $\mathrm{mm}$. Neotype: $5.9 \mathrm{~mm}$. 
Material examined: nine specimens: 6 ơ, 2 \$, 1 no genitalia. $40^{*}$, CHILE. Magallanes

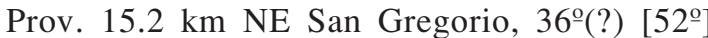
17' S - 71²9' W, 5 m (dunes), XI-27-66, E.I. Schlinger-M.E. Irwin coll.; 2 o', Lag. Amarga, Natales, E of Mt. Payne, $200 \mathrm{~m}$. Magallanes, Chile; 14-20-XII-60, L.E. Peña coll.; 1 \%, Magallanes Prov. $4 \mathrm{~km}$ W Laguna Amarga, 505' S- 724' W, XII-7-1966, M.E. IrwinE.I. Schlinger coll.; 1 @ Bahía Municiones, Magellan Strait, T. del Fuego, 10-XII-60, L.E. Peña coll.; 1 no genitalia. ARGENTINA, Chubut Prov. 19.5 km E Shaman, 650 m, XI19-66, E.I. Schlinger-M.E. Irwin coll.

Dr. Rueda informed that in the collection of Fundación Lillo, Argentina (Colección IFML), there are: "1 specimen Rio Negro. El Tronador. II-1946. Vellard; 1 specimen Neuquén. Pucará. I-1954. Sin datos de colector [no collector notes], 1 specimen Neuquén. Lago Lacar, HuaHum. 30-I-1949. Monros; 1 specimen Chubut. Lago Menéndez. II-1945. Castellanos". These specimens were not studied in this work.

Geographic distribution: as in Fig. 30D.

Discussion: this species is easily distinguishable from other species of the genus by the two different kinds of bristles on mystax, and the fusiform, depressed, white hairs against the integument on the legs. In other species of the genus, like leucotrica $\mathrm{n}$. sp., there are also white hairs in almost all the body, but those are erect and cuneiform (normal).

Designation of neotype is justified because in the last 120 years (since 1882), no references concerning deposit of type have been indicated. This was not communicated, even when the specie was described.

Tillobroma critesi (Artigas) (Fig. 10A-10G, $28 D, 30 C)$

Hypenetes critesi Artigas, 1970: 124, Chile.

Tillobroma critesi (Artigas). Artigas \& Papavero, 1991 (n. comb.).

Type: holotype male [Chile] Balmaceda, Aysén. Ene. 6, 1961, L. Peña. Deposited in Museo de Zoología de la Universidad de Concepción (MZUC-UCCC). Seen.

Diagnosis: head with mystax well developed, all bristles similar in thickness, black, with no more than four white bristles. Facial gibbosity with dull, gray micropubescence. First flagellomere as in Fig. $10 \mathrm{~A}$, the capitulum and pedicel black; scape and pedicel with black and white bristles. Pronotum with white hairs and fine white bristles; mesonotum with black bristles; marginal scutellar bristles black; scutellar disc with gray micropubescence, no bristles; bristles on katatergite black. Coxa with hairs and bristles white; femora unicolor, hind femur without bristles on ventrad-lateroventrad area, hairs are long and white; front tibia brown, with normal white hairs, bristles are long and yellow, as long as the basitarsus; hind tibia with long hairs mostly white, moderately in length, bristles yellowish-red. First tergite with white bristles; tergites dark shiny, with a triangular white spot on sides and dorsum; tergites forth to seventh with yellowish-red reflections. Wings uniform hyaline, without spots; veins fuscate. Male genitalia (Fig. 10B10E), uniform reddish-brown; hypandrium reaches tip of gonopods, apex gently curved downward, no spines on tip; gonopod short, reddish-brown. Cercus large, bent up in straight angle (posterior view in Fig. 10E); aedeagus as in Fig. 28D.

Female: similar to male. Ovipositor as in Fig. 10F; spermatheca as in Fig. 10G.

Measurements: total length: $9.5-10.9 \mathrm{~mm}$; Holotype: $8.9 \mathrm{~mm}$. Wing length: $6.5-8.0 \mathrm{~mm}$; Holotype $6.5 \mathrm{~mm}$.

Material examined: 49 specimens: 38 ơ, 11 ᄋ, 1 no genitalia. $10^{\prime \prime}$ Holotype, 1 ㅇ Allotypo,

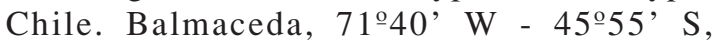
Aysen, 6-I-1961, L.E. Peña; 3 ơ, 1 \%, Chile, Vald. Enco, 120 m, 4/9-III-55, L.E. Peña; $1 \sigma^{\circ}$, Sta. Clara [Ñuble], Dic.-8-63, F. Méndez; $1 \sigma^{\circ}$, $50 \mathrm{~km}$ E of San Carlos, Nuble, Chile, XII-2650; $1 \sigma^{\prime}, 20 \mathrm{~km}$ E of Temuco, Chile, I-7-1951; 3 o' 1 no gen., Lonquimay, 9-enero-1962, L.E. Peña; 2 ơ, Sierra Nevada, Cord. Lonquimay, Enero 1/5-62, L.E. Peña; 1 ơ, La Fusta, Cord. Lonquimay, Febr. 6/21-62, L.E. Peña; $1 \sigma^{\prime \prime}, 1$ , Lonquimay, 6/21-Feb.-62, L.E. Peña; 1 o', Prov. Malleco, Lag. Galletué, 1050 m, 1enero-1968, L.E. Peña; 1 ơ, Bs. Aires, Argentina, I/38, HC Hepper leg.; $2 \sigma^{\circ}$, Argentina, Neuquén, Pucará, 1/54, Dirings; 1 ơ, RA Neuquén, Pucará, Parque Nacional Lanín [Argentina], X/951, Schotovski; 2 o' 1 o, Prov. Cautín, Temuco, Chile, Febr./1967; 1 o', Argentina, Bariloche, Llao-Llao, I/1962, Lane, Coscarón \& Capri; 1 ơ, Prov. 
Llanquihue, NE Vn. Calbuco, 21/22-Enero1969, L.E. Peña; 6 ơ, 4 \%, 2 no genitalia, Icalma, Malleco, 24-II-1975; 1 ᄋ, Fdo. Tres Pinos, Nahuelbuta, Feb. 20-1966, O. Fétis; 1 ơ, Galletué, Cord. Lonquimay, 9-I-1962; 1 ơ, Prov. Nuble, Shangri-La, 21-3-1998, J.C. Ortiz coll.; 1 ơ', Aysén, Coyhaique, 9-II-1956; $1 \sigma^{\circ}$, La Fusta, Cord. Lonquimay, 12-II-1962, J. Valencia coll.; 1 ᄋ, Galletué, Cord. Lonquimay, 11-I-1962, J. Valencia coll.; 1 o", no information, 57; 1 б", 1 \%, Chile. Osorno Prov. $8 \mathrm{~km} \mathrm{~W}$ Refugio La Picada, Vol. Osorno, 350 m, II-6-1967, E.I. Schlinger; 1 ơ, Prov. Nuble, 10 km E Coihueco, 27-dic-1967, L.E. Peña; 1 ơ, Flower Head, Est. San Ramón, Bariloche, Argentina, 2-2-67, IFH; 1 o", Aysén, Coyhaique, 9-II-56; 1 no gen., Lonquimay, 6/21-feb.-1962, L.E. Peña.

Geographic distribution: as in Fig. 30C.

Discussion: this species is close to $T$. valentinei. Females are difficult to separate. In key the color of integument on front tibiae is given: for critesi "dark brown to reddish-brown or lighter that the corresponding femur, at least in basal half; apex could be black", and for valentinei: "black, or same color of correspondent femur, at least in $4 / 5$ of its length". Males are easy to recognize because the apex of hypandrium: in critesi ends pointed and in valentinei clearly spatulate (Fig. 26C and 26D). There is no spines on both species. Other difference: critesi has tergites of dark vitreous color with whitish triangular spots on sides; in valentini tergites are black with gray micropubescence. These differences varies according the state of preservation of the specimens.

Tillobroma davidsoni (Artigas) (Fig. 11A-11G, $27 D, 34 C)$

Hypenetes davidsoni Artigas, 1970: 124. Chile.

Tillobroma davidsoni (Artigas), Artigas \& Papavero, 1991:26 (n. comb.)

Holotype: male, Mitt. Chile, Cauquenes, Schönemann S., 24-4-00 [1900]. Deposited in Museo de Zoología de la Universidad de Concepción (MZUC-UCCC). Seen. Left wing and apex of hypandrium missing.

Diagnosis: head with facial gibbosity shiny black on sides; mystax with bristles of unifom thickness, white on upper part and black on lower part; first flagellomere with pedicel longer than capitulum, as in Fig. 11A, the capitulum is reddish-orange and pedicel darker. Pronotum with fine white hairs and bristles. Mesonotum with black bristles; scutellum with black bristles on hind border, scutellar disc with micropubescence and bristles; mesopleuron with fine scarce hairs on anepisternum; katatergite with black and white bristles. Femora unicolor; hind femur without bristles on posterior face, and with intermingled long hairs black and white; front tibia with black tegument, the long bristles are yellow, the longest ones are as long as the basitarsus, hairs usually white; hind tibia with hairs of normal length, bristles black similar to the ones shown in Fig. 11F. First tergite with hairs and bristles white and black, remaining tergites partially covered by gray micropubescence; tergites 4-7 have no reddish flare. Wings uniformly hyaline, without spots, veins fuscate. Male genitalia (Fig. 11B-11D), reddish- brown, hypandrium similar in length or slightly longer surpassing the apex of epandrium; gonopod with a sinuous process directed backwards; cercus middle sized or large, recurved frontward; aedeagus as in Fig. 27D.

Female: similar to male. Ovipositor as in Fig. 11E. Spermatheca as in Fig. $11 \mathrm{G}$.

Measurements: total length: 11.1-13.5 mm. Holotype: $12.9 \mathrm{~mm}$. Wing length: 7.5-9.1 mm. Holotype: $9.1 \mathrm{~mm}$.

Material examined: 38 specimens: $18 \sigma^{\prime \prime} 11$ \$, 9 no gen. $1 \sigma^{\prime \prime}$, Mitt Chile, Cauquenes, 22-400 [1900], Schönemann S.; 1 o', 1 no gen. Lota, Colcura, 9-IV-61, Orellana coll.; 1 no gen., 1 o", Bulnes, 8-IV-61, Méndez coll.; 2 no gen., Chiguayante, 22-IV-56, R.M.V.; 1 ơ, 1 우, Concepción, 13-IV-61, Orellana coll.; 3 o", 1 ㅇ, 2 no gen., Quillón, 13-IV-62, Méndez coll.; 1 \$, Concepción (Bellavista), 4-IV-61, J. Artigas coll.; 1 o", Quillón, abr. 6-61, Méndez coll.; 1 \$, Cord. Parral, Fdo. Malcho, Enero-57, L.E. Peña coll.; 1 no gen., Concepción, 9-XII-62, Méndez coll.; 1 ơ, 2 \%, 1 no gen., Concepción, 31-marzo-1968, Méndez coll.; $10^{\circ}$, El Canelo, Santiago, 7-XI-1975; 1 ơ", Concepción, Bellavista, 4-IV-61, J. Artigas coll.; 1 o', El Quilaco, Valpo. Chile, abril-1974; 1 \%, Santiago, El Manzano, 17-IX-1967, J. Moroni coll.; 1 o', Tucapel, 30-3-86, Quezada coll.; 1 , San Pedro, 29-I-57, J.R.; 2 \%, Bulnes, 8-IV62, Méndez coll.; 1 \&, Linares, Catillo, 16/21- 
03-72, Exp. Zool. coll.; 2 ơ, 1 no gen., Santiago, C.[cerro] Chena, 15-8-61; 1 o", Horcones, Valparaíso, 7-III-1969, C. Vivar T. coll.; 1 ơ, Marga-Marga, Viña del Mar, 14-IV1951; 1 ơ", Chile, Olmué, 23-III-1929, P. Herbst coll.

Geographic distribution: as in Fig. 34C.

Discussion: species similar to $T$. digitata. Females can be separated almost exclusively by the color of front tibial integument, wich is black in davidsoni or at least of similar color with the correspondent femur; in digitata, this is dark brown, at least different from femur color. Males are easily separated by the genitalia, where in davidsoni: gonopod is globular (Fig. 11D) extending as a posterior process wich does not reaches the apex of epandria; hypandrium slightly attenuated toward apex where bears two strong, short spines; cerci are large, bent at middle in an straight angle, recurvated frontward. In digitata, gonopod extends backwards over the epandrium (Fig. 12B), dorsally is lighter, same times yellowish, contrasting strongly with the color of the hypandrium; hypandrium ends pointed and somewhat flattened, no spines; cerci are small and bent upward at tip.

Tillobroma digitata (Artigas) (Fig. 12A-12F, $27 B, 33 A$ )

Hypenetes digitatus Artigas, 1970: 124. Chile.

Tillobroma digitatus (Artigas). Artigas \& Papavero, 1991: 26

Holotype: male, Lota-Colcura, abril 9, 1961, Orellana. Deposited in Museo de Zoología de la Universidad de Concepción (MZUC-UCCC). Seen. Left antenna missing.

Diagnosis: mystax with homogeneous black bristles all over; sides of facial gibbosity shiny black; pedicel of first flagellomere longer than capitulum as in Fig. 12A, capitulum reddishorange, pedicel darker. Pronotum with white hairs and bristles. Mesonotum with black bristles; border of scutellum with black bristles, scutellar disc with micropubescence and bristles; anepisternum with fine white hairs, katatergite with black bristles. Coxa with fine white hairs and bristles. Hind femur unicolor, without bristles in ventrad-lateroventrad side, long white and black hairs intermingled. Front tibia with reddish integument, the long bristles are yellow an the long hairs black and white intermingled. Hind tibia with long, mostly white hairs, hairs of normal length, similar in length to the basitarsus, bristles black. First abdominal tergite with fine white hairs and bristles. Tergites shiny black, no micropubescence; tergites 4-7 without reddish reflections in dorsum. Wings homogeneous fuscate with few weak spots; veins dark brown. Male genitalia (Fig. 12B-12D), reddish and black in separate areas. Hypandrium does not reaches the apex of gonopods, ending pointed and slightly curved downwards, no spines at tip. Gonopods long, extended over the epandria, both forming a sort of forceps when seen from dorsal view, dorsal part of these extensions are light in color than gonopods, some times yellowish. Cercus small, bent upward at tip in straight angle. Hypandrium and epandria of similar length. Aedeagus as in Fig. 27B.

Female: similar to male. Ovipositor as in Fig. 12E. Spermatheca as in Fig. 12F.

Measurements: total length: 9.5-13.5 mm. Holotype: $13.5 \mathrm{~mm}$. Wing length: $6.8-8.4 \mathrm{~mm}$. Holotype: $8.4 \mathrm{~mm}$

Material examined: 74 specimens: 46 ơ, 19 , 9. 1 ơ", [CHILE]. Lota, Colcura, 9-IV-61, Orellana coll.; $1 \sigma^{\prime \prime}$, Temuco, Mar-8-65, O. Fétis coll.; 1 ơ', 4 no gen., Angol, 20/25-3-57, Parada coll.; 22 o", 14 \%, 1 no gen., VII Región, Curicó, Zapallar, $15 \mathrm{~km}$ E Curicó, Co. HuecaHuecán, marzo 21/31-1998, J.E. Barriga coll.; 1 ơ, Angol, Chile, Febr. 9-1941, P.A. Berry coll.; 1 no gen., Coelemu, 1-mayo-56, L. Longeri coll.; $1 \sigma^{\prime \prime}$, Nahuelbuta, Tres Pinos, Feb. 16-65, O. Fétis coll.; 1 o", Angol, Chile, 36-41, P.A. Berry coll.; 1 o", Mitt. Chile, Contulmo, 23-3-05 [1905], Schönemann S.; 1 ९, Mitt. Chile, Contulmo, 20-3-02 [1902], Schönemann S.; 1 \&, Mitt. Chile, Cauquenes, 23-3-00[1900], Schönemann S.; 1 no gen., Lago Peñuelas, Valpo., 10-10-1964, N. Hichins coll.; 3 o', Bullileo [VII Región], 20-marzo1972, Moyano coll.; 9' $\sigma^{\circ}, 2$ \%, Linares, Catillo, Marz-16/21-1972, Exp. Zool.; 1 ơ, Santiago, Las Condes: Lo Varas, 27-IV-1980, M. Cerda coll.; 1 ơ", La Unión, 29-II-1952; 1 ㅇ, Cocule [X Región], 6-III-1952; 1 no gen., Contulmo, Parque Nacional, 13-III-1976, Quezada coll.; 1 o", Prov. Valdivia, Valdivia, 30-III-71, F.J. Madrid coll.; 1 no gen., Llanquihue, I. Pellines, 6-III-52; 1 ơ, Prov. Valparaíso, I-1922, Faz; 1 ơ, Quebrada Macul, Santiago, 1-IV-1953. 
Geographic distribution: as in Fig. 33A.

Discussion: the distinctive character of this species, which gives it name, is the presence of a long hind apical process in gonopods reaching the tip of hypandrium or, surpassing it (Fig. 12D), instead of other species of the genus, where it reaches at most middle of hypandrium. This character is shared with Tillobroma leucoptera n. sp. (Fig. 17D). Other characters as color and vestiture of tibiae and femora, and structures of male genitalia, allow separation of both species. Females may be confused with females of $T$. davidsoni (Artigas). Differences used to separate females of both species are indicated in $T$. davidsoni discussion.

Tillobroma fucosa (Artigas) (Fig. 13A-13F, $27 G, 33 C$ )

Hypenetes fucosus Artigas, 1970: 124. Chile. Tillobroma fucosus (Artigas). Artigas \& Papavero, 1991: 26.

Holotype: male, Pichinahuel, Cord. Nahuelbuta, Arauco. Chile. 31 jan. 1954, L. Peña, 11-1400 m Deposited in Museo de Zoología de la Universidad de Concepción (MZUC-UCCC). Seen. Left antenna missing.

Diagnosis: head with sides of facial gibbosity mostly shiny black; first flagellomere (Fig. 13A), with capitulum and pedicel black; scape and pedicel with black and white hairs and bristles; mystax with all bristles of same thickness, black, could be near four white bristles intermingled near the oral border. Pronotum with intermingled black bristles and white hairs. Bristles of mesonotum black; scutellum border with black bristles, scutellar disc with micropubescence and in some specimens with few bristles. Mesopleuron with white and black hairs; katatergite with black bristles. Coxae with white hairs. Hind femora unicolor, no bristles on ventrad and lateroventrad part, hairs long mostly black. Tibia brown in all its extension, front tibia with black hairs and bristles, bristles are not longer than the basitarsus. Hind tibia with posterior hairs of normal lenght, black, no longer than half the length of basitarsus; all bristles black. First tergite with black bristles. Tergites 2-4 shiny black with a conspicuous white spot, and a line of micropubescence on dorsal area. Tergite 4-7 with reddish reflections. Wing fuscate, with weak spots; veins light brown.
Male genitalia (Fig. 13B and 13C), reddishbrown; hypandrium extended to apex of epandria; apex of hypandrium blunt, dorsally flattened, bent dowward in straight angle with two, moderate size, divergent, reddish-yellow spines; gonopods reddish-brown, with an apically sinuous process directed backwards. Cercus large, bent upward in mid forming a straight angle. Aedeagus as in Fig. 27G.

Female: similar to male. Ovipositor as in Fig. 13D and 13E; spematheca as in Fig. 13F.

Measurement: total length: 1.3-11.5 mm. Holotype: $11.5 \mathrm{~mm}$. Wing length: 7.3-7.5 mm. Holotype: $7.5 \mathrm{~mm}$.

Material examined: 31 specimens: 20 o', 7 , 4 no genitalia. $2 \sigma^{\prime \prime}, 1$ \%, 1 no gen., CHILE. Pichinahuel, Cord. Nahuelbuta, Arauco, 111400 m, 31-jan-1954, L. Peña coll.; 1 no gen., Las Cabras, Cord. Chillán, 1500 m, 6-31-1963; $1 \sigma^{\prime \prime}$, Alhué; 2 o", Shangri-La, Nuble-Chile, 202-1979; $1 \sigma^{\prime \prime}$, Tres Pinos, Nahuelbuta, Feb. 131966, O. Fétis coll.; 3 o", Las Trancas, NubleChile, Enero-1979; 7 ơ", 6 \%, 1 no gen., La Picada, 600 m, Osorno-Chile, 18/22-1-1980; 3 ơ, 1 no gen., Cord. Las Raíces, Malleco, 1600 m, 13/20-11-80; 1 ơ', Las Garzas, Talca, 18-II67, R. Charlin coll.

Geographic distribution: as in Fig. 33C.

Discussion: the peculiar coloration of abdomen (which gives it name) present in this species, is also present in T. fucosoides n. sp., but both species separate by characters discussed in Tillobroma fucosoides n. sp. T. critesi (Artigas), also presents triangular lateral spots on tergites, but the micropubescence covering the abdomen does not allow to express the conspicuous brilliant blue color on the integument as it happens in this species. This color plus thoracic chaetotaxy, the shape and the presence of spines in apex of hypandrium, and color of tibiae of $T$. fucosoides n. sp., separate both species. New material studied extend original geographic distribution in Chile (Artigas, 1970: 442) to an area between 30 and $40^{\circ}$ latitude South.

Tillobroma fucosoides n. sp. (Fig. 14A-14F, $28 C, 33 D)$

Holotype: male, [Chile] Nahuelbuta, Parque. 12-I-1978, Dr. Cerda coll. This specimen is deposited in Museo de Zoología de la Universidad de Concepción (MZUC-UCCC). 
Diagnosis: body black with scattered areas of golden and white micropubescence. Antennae black. Tibiae reddish in its proximal $1 / 6$, the remainder black. Tibia with abundant intermingled reddish and black bristles. Hypandrium wide, pointed toward apex which is slightly lobulated and has no spines at tip.

Holotype: head in frontal view: face and frons with white micropubescence, frontal hairs black; ocellar bristles black diverging from apical half. Head in side view: facial gibbosity and mystax black; antennae fully black; first flagellomere (Fig. 14A) with a short pedicel, it lenght less than one third the length of capitulum; first and second antennal segment with black hairs; proboscis and maxillary palpi with white hairs ventrad; postocular area with white micropubescence and fine white hairs in lower part, in upper part there are short, proclinate, black hairs, which are more abundant on sides of vertex. Prothorax covered by white micropubescence, more abundant in prothoracic lobes. Thoracic pleuron with areas of golden micropubescence and few fine, white hairs on mesoplura; mesepimeral bristles black, helicoidal toward the apex; mesonotum, scutellum, postscutellum and anatergite with remarkable golden micropubescence arranged in defined areas; dorsocentral lines and lateral spots dark brown; reclinated hairs on anterior part of mesonotum; dorsocentral bristles black and short before the transverse suture and three times longer than it after the suture; three black notopleural bristles; two black intraalar bristles; four black postalar bristles; three black scutellar bristles. Wings slightly fumose, veins dark brown. Coxae black with white micropubescence and fine hairs, abundant on anterior region of frontal coxae; femora shiny black with fine, white, long, erect hairs, mixed with short, white depressed hairs, it has a black spine near the apex; apex of femora and basal third of tibiae light brown, contrasting with the black condition of the remain of leg; tibiae with few short black bristles; mid tibia with few fine long weak black bristles. Abdomen shiny, with bluish reflections and well defined triangular spots on sides of tergites, continuing as a white line along posterior border of tergites; first tergite almost fully covered with micropubescence and fine white hairs; on laterad with three black bristles mixed with abundant white long fine hairs similar in length to the bristles; pilose vestiture of remaining tergites, of uniform, reclinate, white, short, white hairs. Male genitalia (Fig. 14B and 14C) light brown, with abundant reclinate, black hairs, longer than the epandria; hypandrium wide, bent downward at apex, wich is bilobulated, no spines at tip. Aedeagus (from a paratype) as in Fig. 28C.

Allotype female: similar to Holotype. Ovipositor as in Fig. 14D and 14E. Spermatheca (from a paratype) as in Fig. 14F.

Measurements: total length: $8.3 \mathrm{~mm}$ (paratypes 7.8-11.4). Wing length: $6.3 \mathrm{~mm}$ (paratypes 5.6-7.8 $\mathrm{mm}$ )

Material examined: 26 specimens: 17 ơ, 7 \$, 2 no genitalia. 1 o Holotipo, [Chile] Nahuelbuta, Parque. ‘12-I-1978, Dr. Cerda coll.; 1 \& Allotipo, Arauco Prov., Cord. Nahuelbuta, $20 \mathrm{~km} \mathrm{~W}$ Caramávida (314' S-7321' W), 750 m. I-31-67, E.I. Schlinger coll.; Paratipos: 1 ơ", Nahuelbuta, Parque Cabrería. 14-I-1978, G. Cerda B.; 2 o", Arauco Prov., Cord. Nahuelbuta, $20 \mathrm{~km}$ W Caramávida (31ํㅜㄱ' 73을 21'W), 750 m. I-31-67, E.I. Schlinger coll.; 3 ơ, 3 , 1 no gen., La Selva, 700 m. Nva. Imperial, Chile, II-81, L.E. Peña coll.; 3 o', 1 \%, Cabrería, Nahuelbuta, Arauco, Chile. 21/23-II79; 1 o", Cabrería, 1100 m, Cord. Nahuelbuta, 23/31-1-1977; 1 ㅇ, Las Cabras, 31-enero-1963, L. Peña coll.; 4 o', 1 \&, Chile, Valdivia, W La Unión, 1-1989, L.E. Peña coll.; 1 'ơ', Prov. Arauco, Caramávida, 700-1000m, 30-enero1967, L.E. Peña coll.; 1 no gen., El Coigo, Curicó-Chile, 11/31-1-1960, L.E. Peña coll.; 1 $0^{\prime \prime}$, Malleco Prov. 37.809 S-73.916 $\mathrm{O}$ W, Parque Nacional de Nahuelbuta, 3680 ft, 6-jan-2000, DWW ebb.

Geographic distribution: as in Fig. 33D.

Discussion: this species is slightly similar to T. fucosa (Artigas) because the color of the abdomen, and the general appearance of the body. This similarity gives it name fucosoides. This species has the tibiae bicolor, reddish in the upper third and black in the remaining two third. Instead, T. fucosa has the tibiae entirely brown. Male genitalia separate both species: in fucosoides (Fig. 14B and 14C) hypandrium apex is anarmed and in fucosa (Fig. 13B and 13C) there are two well developed spines at tip. 
Tillobroma fulvicornis (Macquart) (Fig. 15A$15 G, 30 A$ )

Dasypogon fulvicornis Macquart, 1846: 196 (1846: 67) pl. 7 Fig. 6. Brasil (nec Dasypogon fulvicornis Macquart, 1834: 296-297, France).

Hypenetes fulvicornis (Macquart). Reed, 1888: 188 (n. comb..); Engel, 1929: 457; Bromley, 1932: 264; Hull, 1962: 154.

Tillobroma fulvicornis (Macquart). Artigas \& Papavero, 1991 (n. comb.)

Type: type locality: Brasil. Holotype MNHNP.

Original description (translated from latin): "Thorax gray with black stripes. Abdomen shiny black. Mystax black. Antennae reddish, with black apex. Legs black, front tibiae brown".

Diagnosis. Male: head in frontal view: face and front covered with dense golden micropubescence; frontal hairs black; ocellar bristles black. Head in lateral view: facial gibbosity dark; mystax of thick black bristles; antennae brown; third flagellomere (Fig.15A), with pedicel as long as capitulum, reddish at base, apex dark; hairs on antenna, black; beard white; postocular vestiture white, with abundant short black bristles in upper half, faintly proclinate and with fine white hairs on lower half; maxillary palpi black with white hairs. Prothorax with golden micropubescence and some white hairs; thoracic pleuron with abundant areas of golden micropubescence; dorsocentral lines and lateral spots brown, vestiture of short thick, black hairs; 8-10 black dorsocentral bristles; two black notopleural bristles; one black intraalar bristle; six black postalar bristles; four pairs of black scutellar bristles. Anatergite with golden micropubescence. Wings with dark venation and brown spots on bifurcation of R2 and R3, extending along veins. Hair vestiture of coxa, similar to thoracic pleuron: white hairs of woolly aspect, more abundant in front coxa. Femora black; tibiae and tarsi brown, with abundant white erect, pilosity; hind femora with six spines on ventral side, near apex, arranged along sides of ventral margin in two parallel rows of three spines on each side; reddish and black spines mixed on front and middle tibiae; hind tibia with black bristles. Abdomen brown, with golden micropubescence, more abundant along the posterior border of each tergite; white hairs on tergites, more abundant on first three. Male genitalia (Fig. 15B-15D), brown, two times wider than abdomen; hypandrium slightly longer than epandria, curved and attenuated toward apex with two short brown spines at tip; gonopods half length of hypandrium, with three parallel bristles, two times longer than gonopod and directed backwards.

Female: similar to male. Ovipositor (Fig. $15 \mathrm{E}$ and $15 \mathrm{~F})$, black with black spines; spermatheca as in Fig. 15G.

Measurements: total length: $85-13.5 \mathrm{~mm}$. Wing length: 6.5-9.5 mm.

Material examined: 11 specimens: $50^{\circ}, 3$ ㅇ, 3 no gen.. $1 \sigma^{\prime}$ Neotype: Nova Teutonia, Brasil. 4-22-1948, F. Plaumann coll.; 1 ơ, Nova Teutonia, Brasil. 4-22-1948, F. Plaumann coll.; no gen., Brasil, Rio de Janeiro, Itatiaia, 5001000 m, VIII-46, Barretto; 1 no gen., Brasil, S. Paulo, S. Amaro, VIII-61, J. Lane coll.; 1 no gen, Brasilien, Nova Teutonia, 27ำ $11^{\prime} \mathrm{B}-62^{\circ}$ 23' L, 300-500 m, 21-4-1951, Fritz Plaumann coll.; 1 o", Brasil, S. Paulo, Camp. do Jordao, Agosto-949, J. Lane coll.; 1 o", Est. Biol. Boraceia, Salesópolis, S.P., 25-X-1968, E.X. Rabello coll.; 1 ᄋ, Theresopolis, E. do Rio, Brasil, 1519 m, 12/20-VII-959, J.H. Guimaraes coll.; 1 \&, Nova Teutonia, S.C., V-1948, F. Plaumann coll.; 1 ơ, Nova Teutonia, S.C. Brasil, VIII-1967, F. Plaumann coll.; 1 , Brasilien, Nova Teutonia, 27ํ 14'B-52 $23^{\prime} \mathrm{L}$, 300-500 m, 26-3-1951, F. Plaumann coll. Dr. Cristina Rueda, from Fundación Miguel Lillo (Argentina), informed that in such collection, there is 1 specimen, Tucuman, Va. Padre Monti. 11-V-1948, Wygodzinsky. This specimen was not studied in this work.

Geographic distribution: Brasil, according Artigas \& Papavero, 1991: 26 (fig. 161). Former known distribution: Cordillera von Buena Vista Südl. Cuervo (Bolivia). 10-VII-26 (Engel, 1929: 474). Fig. 30A.

Discussion: this is one of the three species of the genus Tillobroma not present in Chile: obtusa (Engel) and fulvicornis (Macquart) from Brasil and spinipes n. sp. from Argentina. Males and females of $T$. fulvicornis have two rows of four to six spines on hind femora, located on ventrad lateroventrad border. This character is sheared with $T$. spinipes n. sp. Male wings of $T$. fulvicornis have a peculiar spot on bifurcation of $\mathrm{R} 2+3$ with $\mathrm{R} 4+5$, which 
is lacking in females. This spot is frequent among the species of Hypenetes Loew (posible sister genus of Tillobroma) of South African distribution. The remaining species of Tillobroma lacks this spot, or it is very weak in few species.

Tillobroma huasquina n. sp. (Fig. 16A-16F, 33B)

Holotype: male. Chile Prov., 10, 3 km N Puerto Huasco; coastal dunes: 1-X-1997. M.E. Irwin, D.K. Yeates, $28.4379^{\circ}$ S-71. $1896^{\circ}$ W. Allotype same references.

Diagnosis: body black with gray micropubescence. First flagellomere black, pedicel short, no more than $1 / 4$ the length of capitulum. Mystax with long thick, black bristles on upper half, fine and white on lower half. Femur and tibia black, with white hairs and bristles. Wings hyaline, no spots. Hypandrium with distal half narrow, with two yellowish-white spines on apex.

Holotype: head with ocellar and frontal bristles long and black; postocular bristles fine, short and white; scape and pedicel black, with white hairs and bristles; first flagellomere (Fig. 16A) black, with pedicel of flagellomere $1 / 4$ to 1/5 length of capitulum; mystax with thick, long, black bristles in upper half, in lower half and oral border bristles are fine, white and more dense than the upper ones; palpi and proboscis black, with white fine hairs. Mesonotum black with gray micropubescence, mesonotal bristles black, with fine white hairs intermingled; two white notopleural bristles; two black intraalar bristles; hind callus with black and white bristles; scutellum with gray micropubescence and fine white hairs, three pairs of long thick black bristles on posterior border. Mesopleuron with fine scattered white hairs; katatergite with white bristles. Coxae, femora and tibiae black, with fine white hairs; all bristles on tibiae white, similar in thickness and length, longest ones are as long as basitarsus; tarsus black, toward apex becomes lighter an brownish, tarsal hairs and bristles as in tibia; claw reddish-brown on basal half and black on apex; pulvilli white, empodium yellowish brown. Wing without spots, veins light brown. Abdomen black with gray micropubescence and short, fine, white hairs. First tergite with white bristles. Male genitalia
(Fig. 16B and 16C) reddish-brown with white hairs; apical half of hypandrium strongly attenuated and slightly bent downward in almost $90^{\circ}$ with two white spines on apex, these spines are as long as $1 / 3$ the length of the attenuated part of hypandrium; gonopod short globular, reaching mid hypandrium, with an small apical extension wide, truncate and flattened, slightly lighter in color than gonopod; epandria almost black at apex, not reaches tip of hypandrium; cercus large, bent up in middle.

Allotype. Female. Similar to Holotype. Ovipositor (Fig. 16D) with the eighth tergite flattened at dorsum, similar in color to preceding tergites; eighth sternite reddish, extended far beyond tip of tergite; five black spines on each acanthophorite. Spermatheca (from a paratype), as in Fig. 16D and 16E.

Measurements: total length: $6.2-8.0 \mathrm{~mm}$. Holotype: $6.5 \mathrm{~mm}$. Wing length: $5.0-5.4 \mathrm{~mm}$. Holotype: $5.1 \mathrm{~mm}$.

Material examined: 13 specimens. 100 Holotype, 3 o paratypes; 1 \% Allotype, 7 \% paratypes, Chile. Huasco Prov. 10 m, 3 km N Puerto Huasco, coastal dunes, 28.4379 $\mathrm{S}$ 71.1896ํㅡ. W. 1-X-1997, M.E. Irwin-D.k Yeates coll.; $10^{\circ}$, Paratype, Piedra Colgada, Prov. Atacama (Cent. Ent. U. de Chile), 19-9-65, Montes coll.

Geographic distribution: as in Fig. 33B.

Discussion: this species is named after tipe locality: Huasco. Can be recognized by its general black color, all bristles of legs white long and scattered and the particular condition of mystax with upper half bristles thick long and white, contrasting with the long fine white bristles on lower half. Latter remember the mystax condition of $T$. asiliformis (Wulp) and T. leucotrica $n$. sp.

Tillobroma leucoptera n. sp. (Fig. 16E-17D, 28H, 31A)

Holotype: male. [Chile]. C. Poqui, O'Higgins, 1,500 m, 20/24-3-51 [1951], L. Peña col. Both antennae are missing. Deposited in the Museo de Zoología de la Universidad de Concepción (MZUC-UCCC).

Diagnosis: body robust, with abundant areas of golden micropubescence. Legs with abundant, long, fine, golden hairs and, abundant black bristles, intermingled with light 

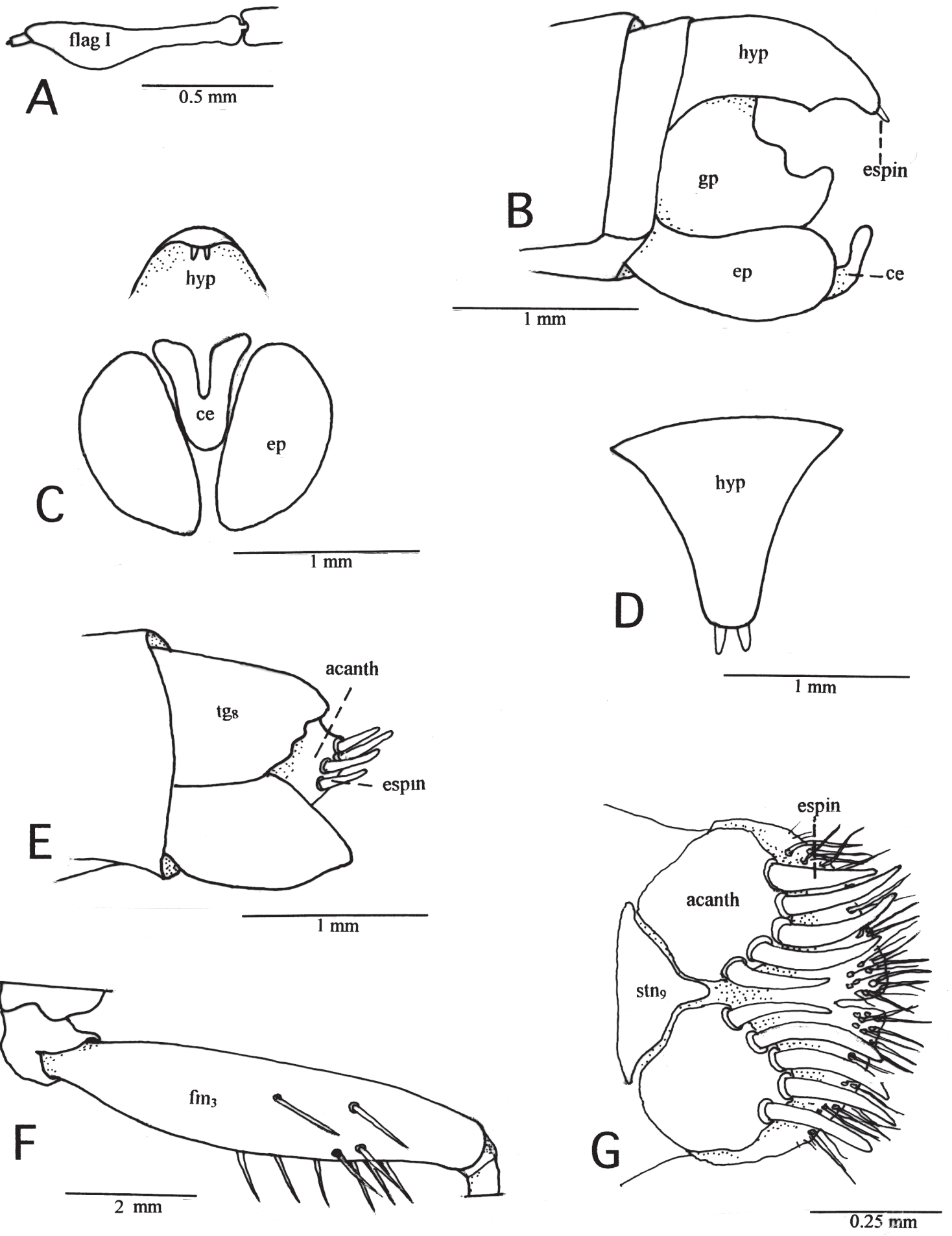

Fig. 21: Tillobroma punctipennis (Philippi) (neotype, except E and F). (A) Antenna in side view; (B) male genitalia in side view; (C) male genitalia from hind view; (D) hypandrium in dorsal view; (E) ovipositor in side view; (F) acanthophorites in ventral view; (G) hind femur (hairs not shown).

Tillobroma punctipennis (Philippi) (neotipo, excepto E y F). (A) Antena en vista lateral; (B) genitalia del macho en vista lateral; (C) genitalia del macho en vista posterior; (D) hipandrio en vista dorsal; (E) ovipositor en vista lateral; (F) acantoforitos en vista ventral; $(\mathrm{G})$ fémur posterior (pelos omitidos). 


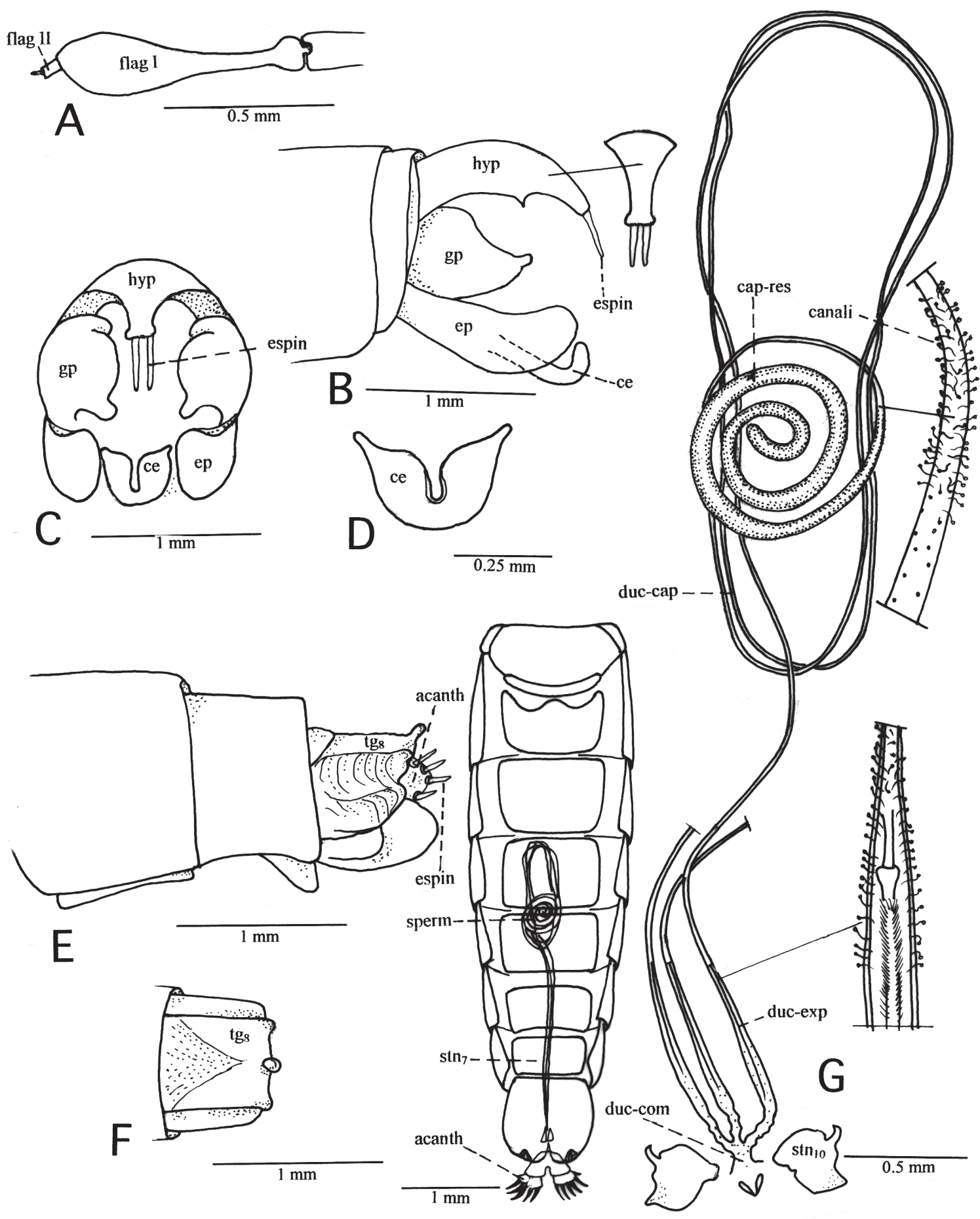

Fig. 22: Tillobroma purpurea n. sp. (holotype, allotype, except G: paratype). (A) Antenna in side view; (B) male genitalia in side view; detail of hypandrium apex in dorsal view; (C) male genitalia from hind view; (D) cerci in dorsal view; (E) ovipositor in side view; (F) ovipositor in dorsal view; (G) abdomen in ventral view, shows position of the spermatheca; spermatheca and details.

Tillobroma purpurea n. sp. (holotipo, alotipo, excepto G: paratipo). (A) Antena en vista lateral; (B) genitalia del macho vista lateral; detalle del ápice del hipandrio en vista dorsal; (C) genitalia del macho en vista posterior; (D) cercos en vista dorsal; (E) ovipositor en vista lateral; (F) ovipositor en vista dorsal; (G) abdomen en vista ventral, muestra posición de espermateca; espermateca y detalles. 


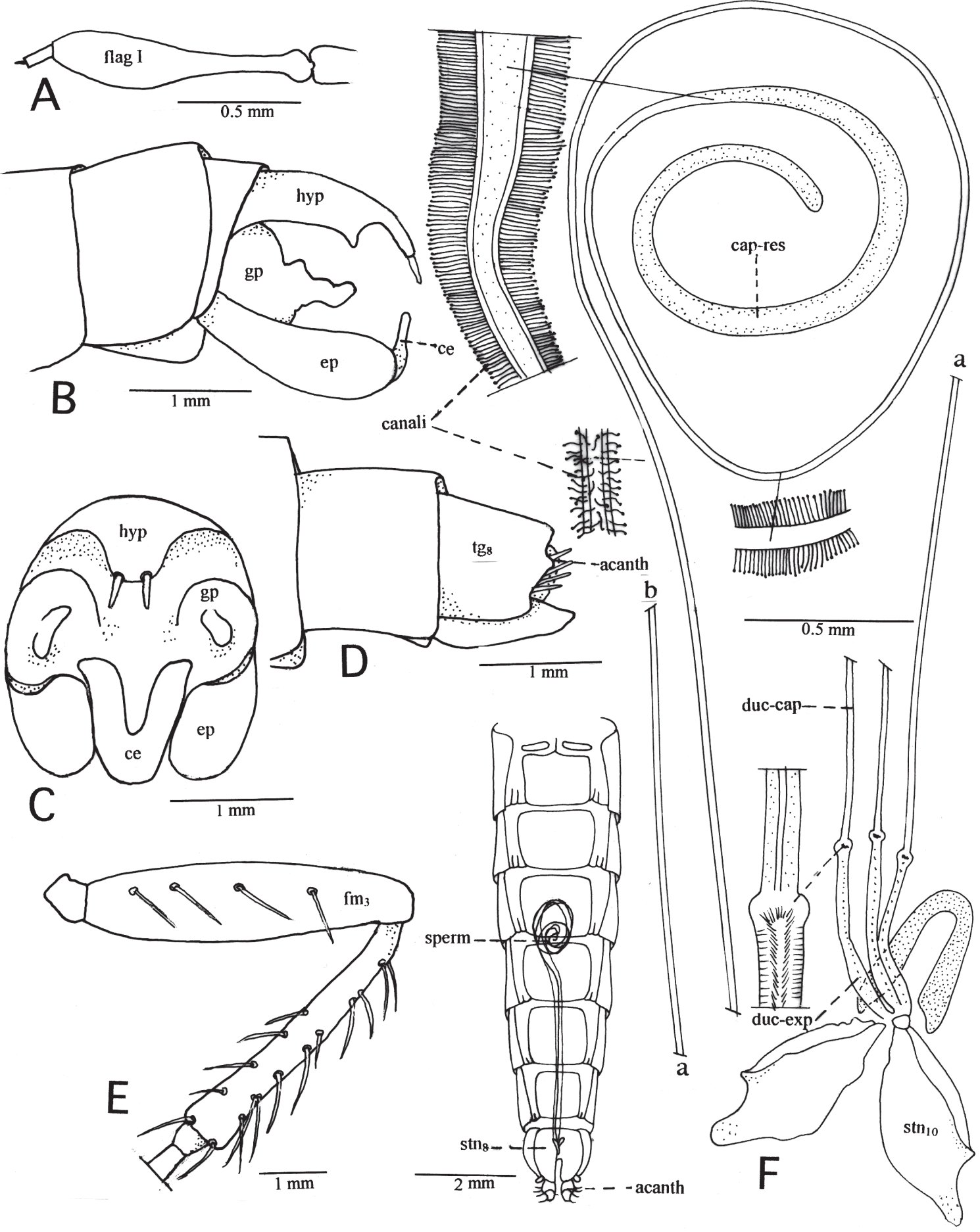

Fig. 23: Tillobroma schineri (Artigas). (A) Antenna in side view (paratype); (B) male genitalia in side view (holotype); (C) male genitalia from hind view (holotype); (D) ovipositor in side view (allotype); (E) femur and tibia hind (holotype) (hairs not shown); (F) abdomen in ventral view, shows position of spermatheca; spermatheca and details.

Tillobroma schineri (Artigas). (A) Antena en vista lateral (paratipo); (B) genitalia del macho en vista lateral (holotipo); (C) genitalia del macho en vista posterior (holotipo); (D) ovipositor en vista lateral (alotipo); (E) fémur y tibia posterior (holotipo) (pelos omitidos); (F) abdomen en vista ventral, muestra posición de espermateca; espermateca y detalles. 

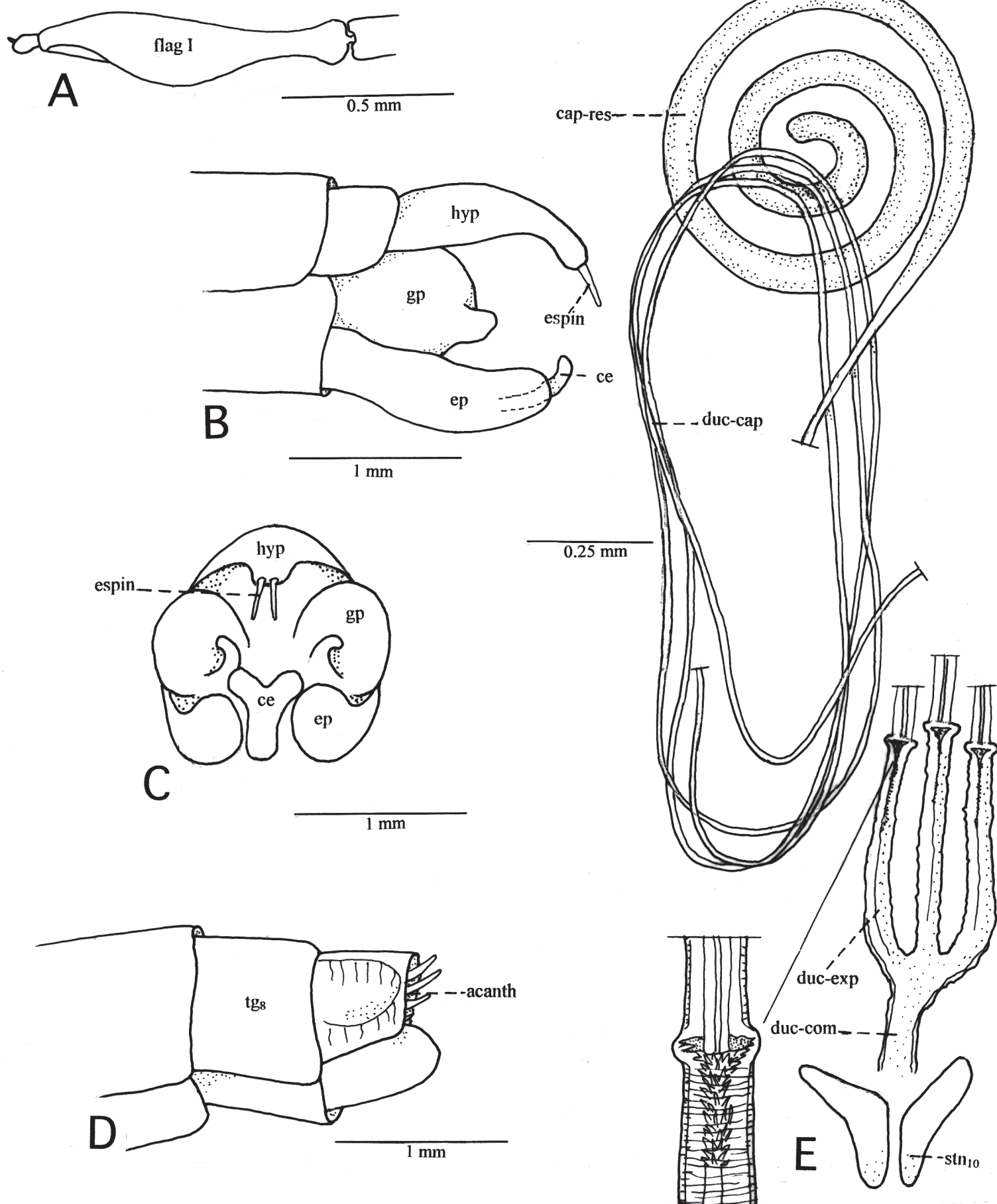

Fig. 24: Tillobroma spinipes n. sp. (holotype, allotype, except E: paratype). (A) Antenna in side view; (B) male genitalia in side view; (C) male genitalia from hind view; (D) ovipositor in side view; (E) spermatheca and details.

Tillobroma spinipes n. sp. (holotipo, alotipo, excepto E: paratipo). (A) Antena en vista lateral; (B) genitalia del macho en vista lateral; (C) genitalia del macho en vista posterior; (D) ovipositor en vista lateral; (E) espermateca y detalles. 


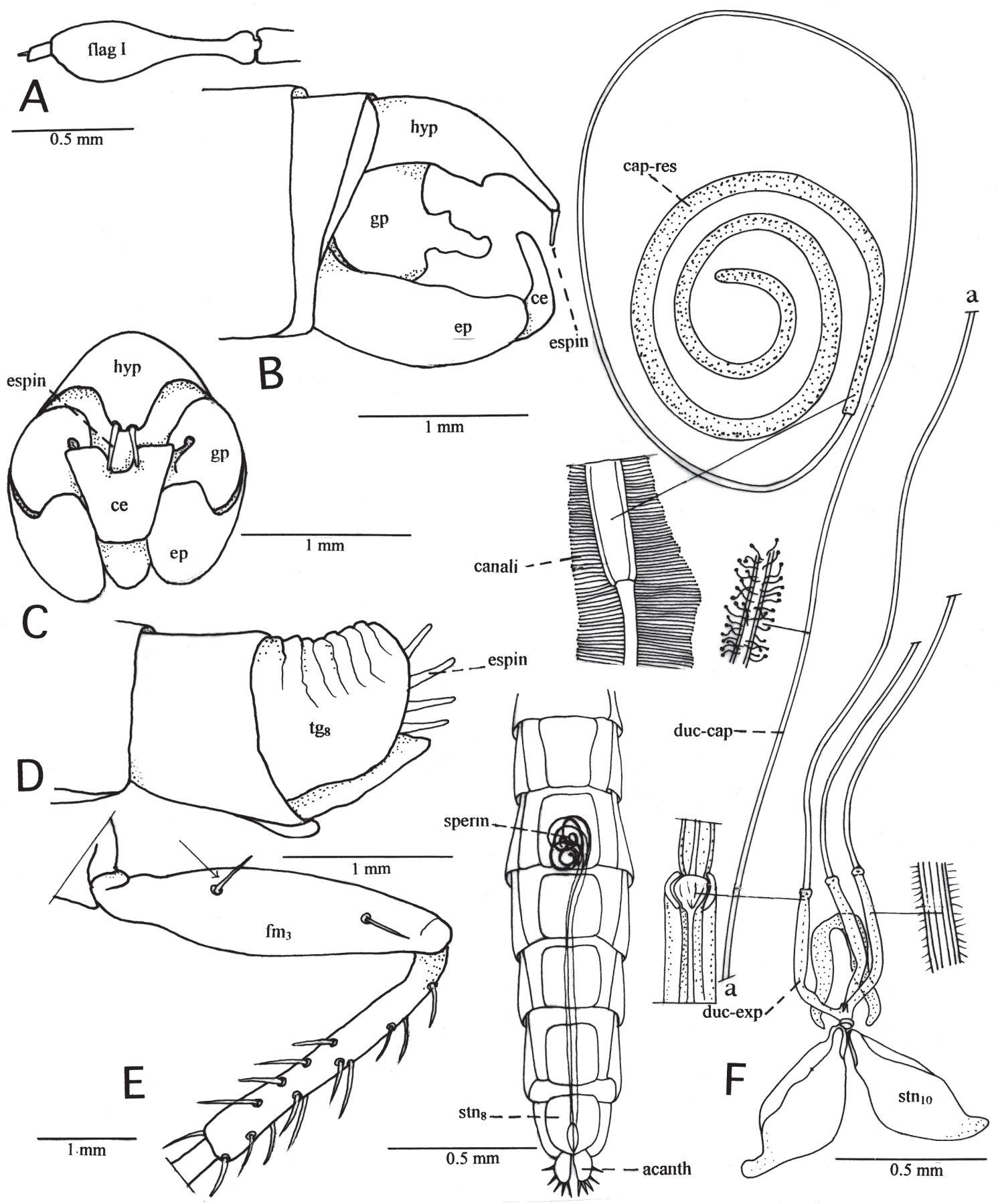

Fig. 25: Tillobroma tregualemuensis n. sp. (holotype, allotype, except F: paratype). (A) Antenna in side view; (B) male genitalia in side view; (C) male genitalia from hind view; (D) ovipositor in side view; (E) femur and tibia hind (hairs no shown; indicated bristle only in allotype); (F) abdomen in ventral view, shows position of spermatheca; spermatheca and details.

Tillobroma tregualemuensis n. sp. (holotipo, alotipo, excepto F: paratipo). (A) Antena en vista lateral; (B) genitalia del macho en vista lateral; (C) genitalia del macho en vista posterior; (D) ovipositor en vista lateral; (E) fémur y tibia posterior (pelos omitidos; cerdas indicadas solo en el alotipo); (F) abdomen en vista ventral, muestra posición de espermateca; espermateca y detalles. 

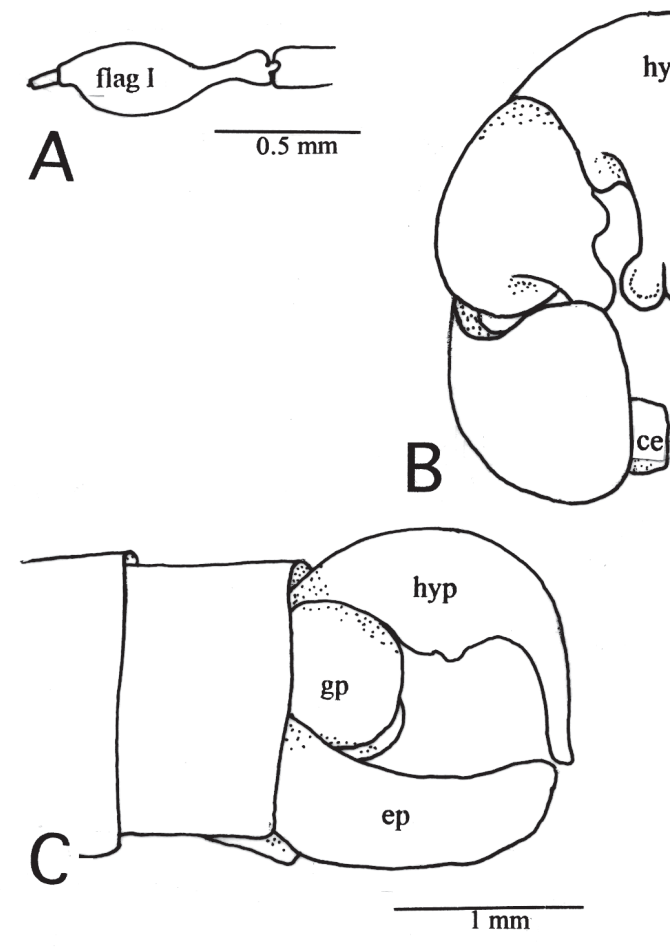

hyp
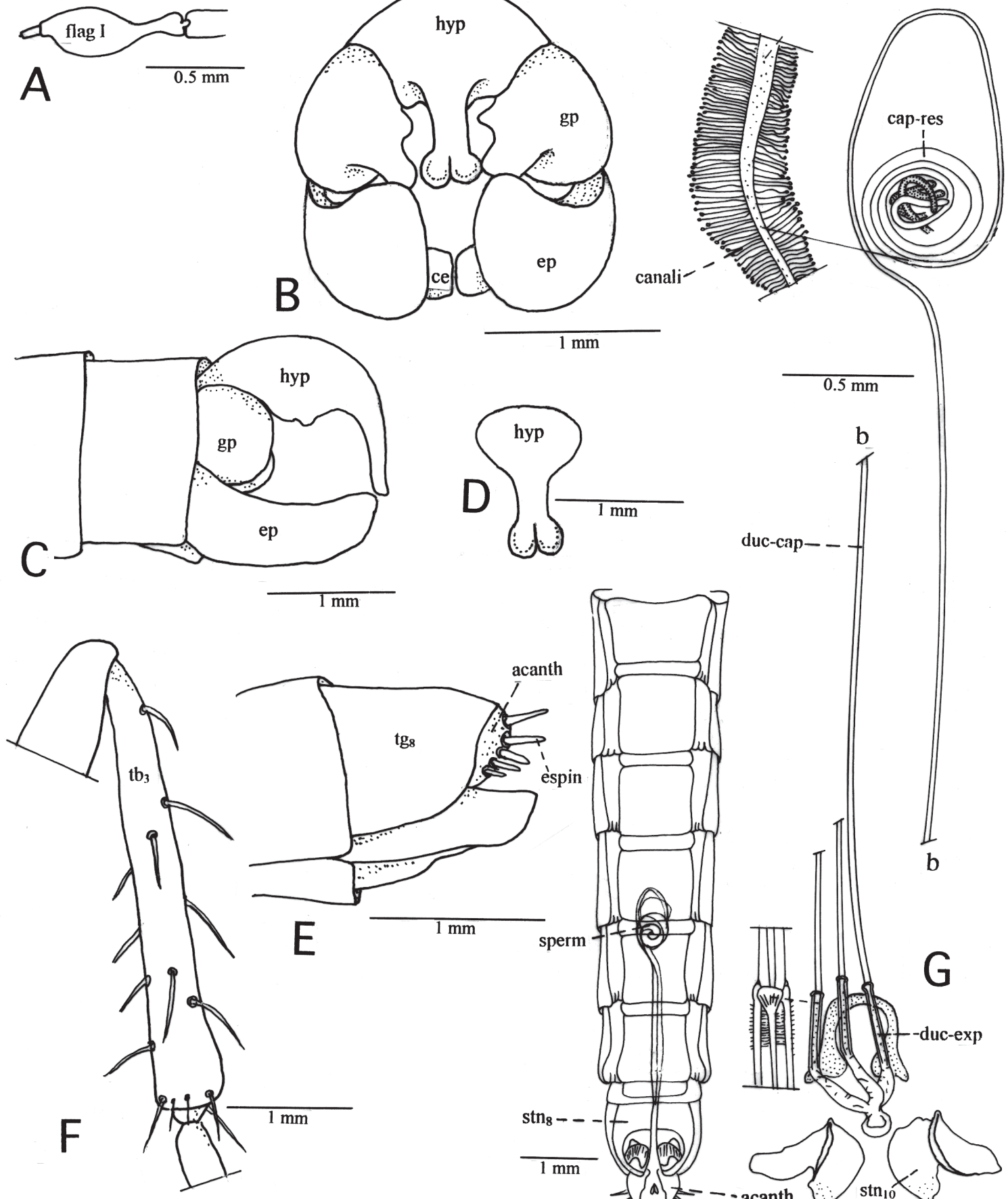

Fig. 26: Tillobroma valentinei (Artigas). (A) Antenna in side view (paratype); (B) male genitalia in side view (holotype); (C) male genitalia from hind view (holotype); (D) hypandrium in dorsal view (holotype); (E) ovipositor in side view (allotype); (F) hind tibia (holotype); (G) abdomen in ventral view, shows position of the spermatheca; spermatheca and details (paratype).

Tillobroma valentinei (Artigas). (A) Antena en vista lateral (paratipo); (B) genitalia del macho en vista lateral (holotipo); (C) genitalia del macho en vista posterior (holotipo); (D) hipandrio en vista dorsal (holotipo); (E) ovipositor en vista lateral (alotipo); (F) tibia posterior (holotipo); (G) abdomen en vista ventral, muestra posición de espermateca; espermateca y detalles (paratipo). 

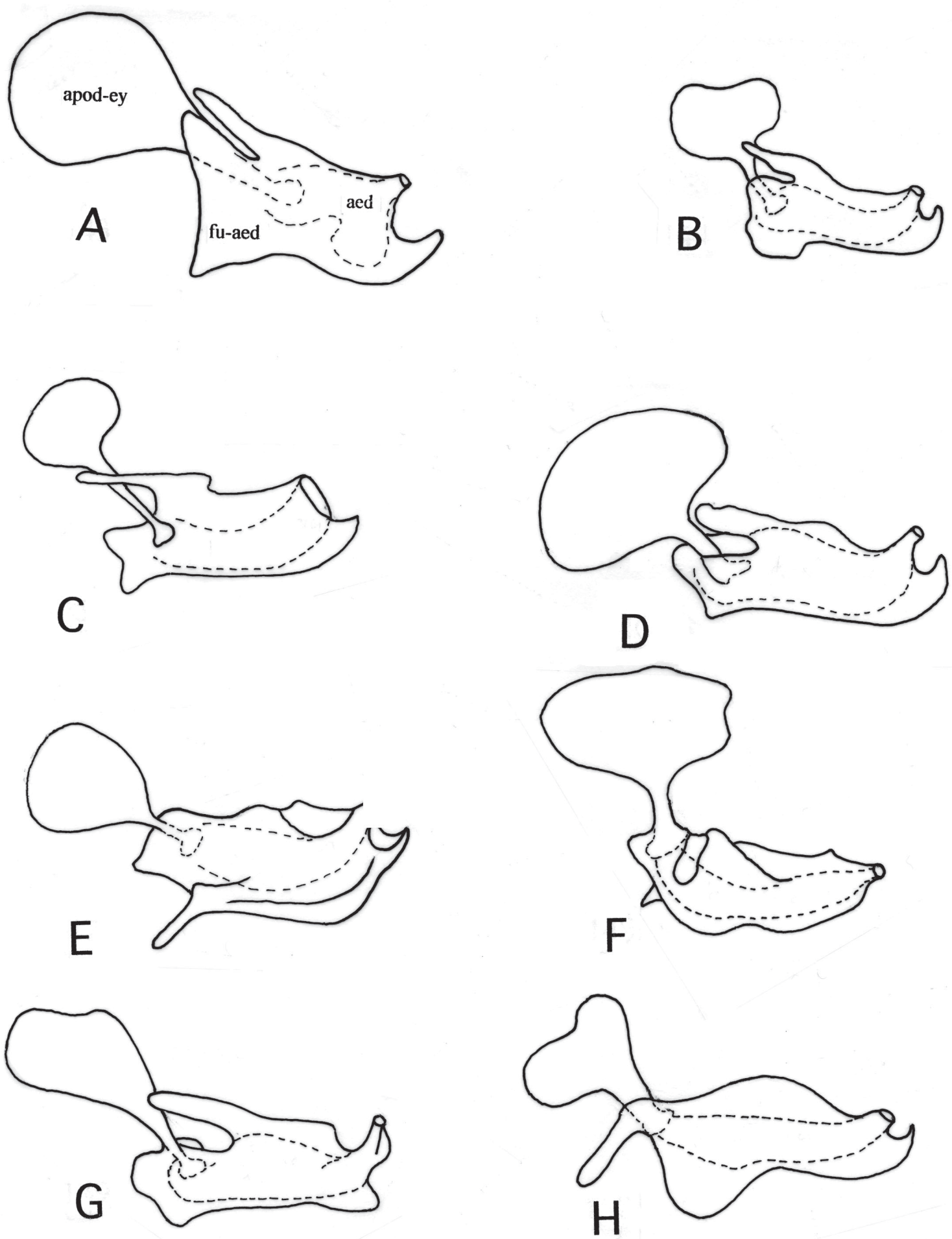

Fig. 27: Tillobroma spp.: aedeagus. (A) T. punctipennis (Philippi); (B) T. digitata (Artigas); (C) T. valentinei (Artigas); (D) T. davidsoni (Artigas); (E) T. asiliformis (Wulp); (F) T. angulata n. sp. (paratype); (G) T. fucosa (Artigas); (H) T. tregualemuensis n. sp. (paratype).

Tillobroma spp.: edeago. (A) T. punctipennis (Philippi); (B) T. digitata (Artigas); (C) T. valentinei (Artigas); (D) T. davidsoni (Artigas); (E) T. asiliformis (Wulp); (F) T. angulata n. sp. (paratipo); (G) T. fucosa (Artigas); (H) T. tregualemuensis $\mathrm{n}$. sp. (paratipo). 

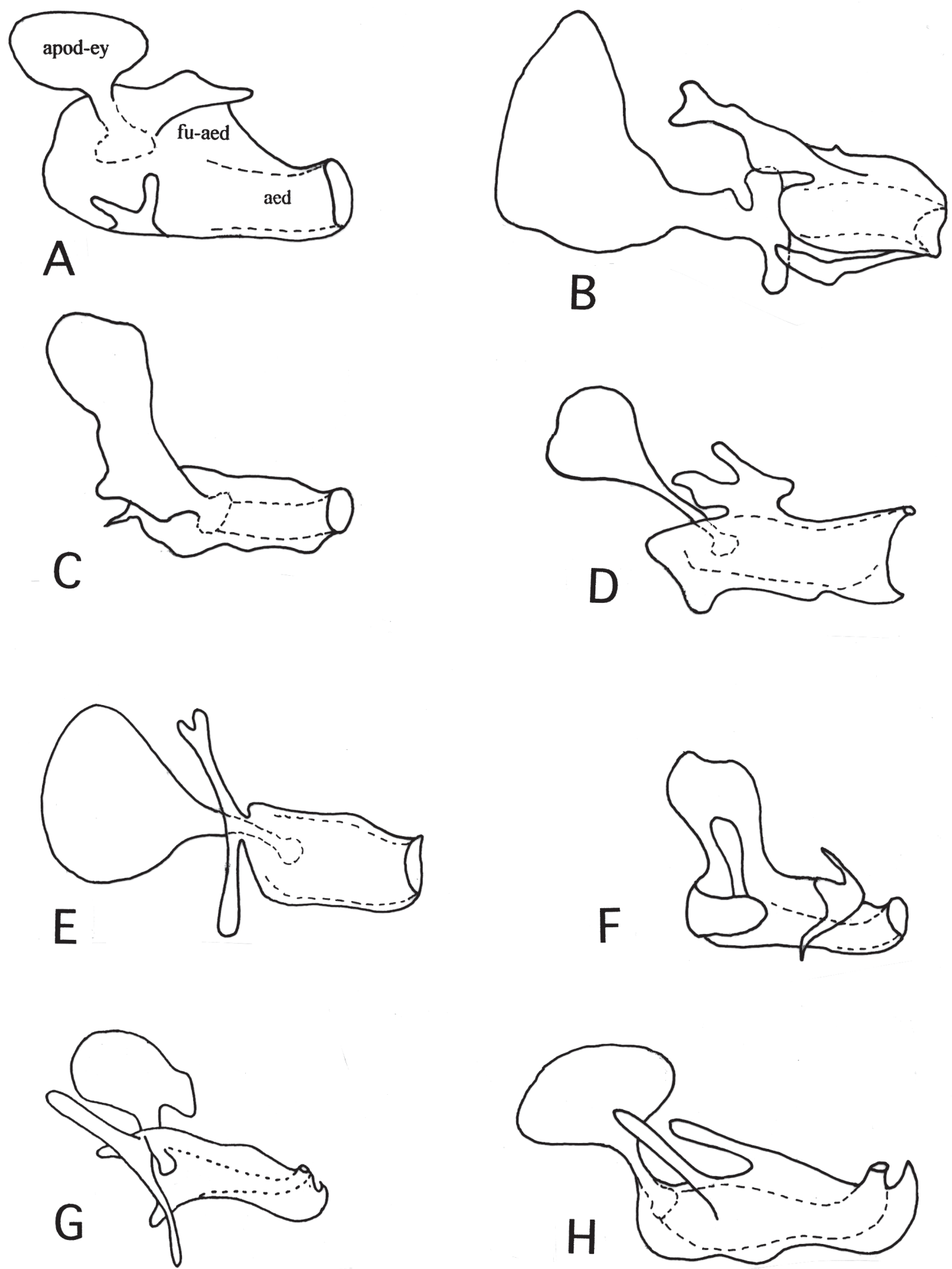

Fig. 28: Tillobroma spp.: aedeagus. (A) T. leucotrica n. sp. (paratype); (B) T. purpurea n. sp. (paratype); (C) T. fucosoides n. sp. (paratype); (D) T. critesi (Atigas); (E) T. magellanica (Artigas); (F) T. nahuelbutae n. sp. (paratype); (G) T. schineri (Artigas); (H) T. leucoptera n. sp. (paratype).

Tillobroma spp.: edeagos. (A) T. leucotrica n. sp. (paratipo); (B) T. purpurea n. sp. (paratipo); (C) T. fucosoides n. sp. (paratipo); (D) T. critesi (Artigas); (E) T. magellanica (Artigas); (F) T. nahuelbutae n. sp. (paratipo); (G) T. schineri (Artigas); (H) T. leucoptera $\mathrm{n}$. sp. (paratipo). 
brown bristles. Basal half of male wings milky white, remaining of wing, hyaline. Pedicel of first flagellomere, as long as the capitulum. Apex of hypandrium spoon shaped, without spines on tip.

Holotype: head in frontal view: Face and front black, with abundant white micropubescence, which gives a general golden condition; on ocellarium there are long, black, divergent hairs, similar hairs, but shorter, in front. Head in side view: facial gibbosity black, mystax black, dense, with few white hairs in the lower part; antennae (from a paratype), black, first flagellomere (Fig. 17A), reddish, the stem as long as the capitulum; white hairs on scape and black on pedicel; beard white; ventral area of proboscis with white hairs mixed with black hairs. Postocular area black, with abundant white micropubescence, with black hairs gently undulated in apical part, more abundant and longer on sides of vertex. Prothorax with abundant areas of golden micropubescence, and fine, long, white hairs, more abundant on prothoracic lobes. Thoracic pleuron with large areas of golden micropubescence; mesopleuron with fine, white hairs in the upper part, and black hairs, more abundant and longer in the inferior part; mesonotum and scutellum covered, in part, with golden micropubescence, more noteworthy on sides of dorsocentral lines, latter with black vestiture; humeral and posterior callus with fine, white hairs; presutural dorsocentral bristles short, postsuturals twice in length; two black notopleural bristles; two black intraalar bristles; 14 fine black, postalar bristles; five black postscutellar bristles; katatergite with abundant, fine, black bristles; anatergite covered with white micropubescence. Wing milky white in basal half and hyaline on apical half; veins light brown. Coxae with areas of golden micropubescence and fine, white hairs, mainly abundant on frontal area of front coxa; femur brown; tibia slightly lighter than femur; legs vestiture of abundant white hairs, more abundant on femora; front and middle tibiae with strong, mixed, white and brown bristles; hind tibia only with black bristles; hind femur on external side with a brown spine on apex and a black spine near base. Abdomen black, covered by golden micropubescence and long fine, white hairs all over, more abundant on sides of tergites; four weak black bristles on each side of first tergite, intermingled with white hairs. Male genitalia (Fig. 17B-17D) light brown, with abundant long, reclinate, black hairs; no spines on apex of hypandrium; gonopod with a large, digitiform process directed backward, reaching the apex of hypandrium. Aedeagus (from paratype) as in Fig. 28H.

Female: unknown.

Measurements: total length: 12.3-12.5. mm. Holotype: $12.3 \mathrm{~mm}$. Wing length: $8.2-8.5 \mathrm{~mm}$. Holotype: $8.3 \mathrm{~mm}$.

Material examined: three $\sigma^{\prime \prime}$, one $\sigma^{\prime \prime}$ Holotype. [Chile]. Co. Poqui, O’Higgins, 1,500 m, 20/24-marzo-51[1951], L.E. Peña coll.; $10^{\text {* }}$ paratype Chile. El Salto, Valparaíso, 18-IV1969, J.C. Ortiz coll.; 1 o" paratype, [Chile], Curicó.

Geographic distribution: as in Fig. 31A.

Discussion: this species is named leucoptera because of the milky white color in basal half of wing, contrasting with the hyaline condition of distal half of membrane. This new species is based on only three males. The striking coloration of wings for a Tillobroma on Chile, similar to $T$. obtusa (Engel) from Brasil, encouraged the authors to name it. Both species differ in color of some integumentary elements and strongly in genital structures as gonopods, and apical spines of hypandrium, where leucoptera has gonopod with a long distal projection extended over epandrium (similar to $T$. digitata), and lacks spines on hypandrial tip, while in obtusa, gonopods are globular with short apical rounded process, and hypandrium wears two spines at tip. In both species females are unknown.

Tillobroma leucotrica n. sp. (Fig. 17E-18B, $28 A, 31 D$ )

Holotype: male. Chile. Atacama Prov., 70 km S Copiapo. VIII-18-1966. M.E. Irwing \& E.I. Schlinger. $27^{\circ} 22^{\prime}$ S $-70^{\circ} 20^{\prime} \mathrm{W}$. Allotype: Same locality and data. These specimens are deposited in Museo de Zoología de la Universidad de Concepción (MZUC-UCCC).

Diagnosis: head and body black, with abundant areas of white micropubescence; first flagellomere with a short stalk. All hairs and body bristles white or light brown. Hypandrium long and acute, with two spines at apex. Tibia and tarsus with strong white bristles.

Holotype: head in frontal view: face and front black with areas of white micropubescence and white hairs. Head in side view: facial gibbosity dark; antennae uniform 
dark with abundant white hairs on first and second segments, first flagellomere with the stalk slightly shorter than capitulum (Fig. 17E); ocellar bristles long and white; postocular area dark with white micropubescence and abundant white, proclinate, dense hairs on both sides of vertex; mystax dense, with long white hairs; beard white; there are soft white hairs on ventral part of proboscis; maxillary palpi dark, with white hairs. Prothorax with areas of white micropubescence and long, fine, white hairs, more dense on posterior lobes. Thoracic pleuron with areas of white micropubescence, and white hairs and bristles. Mesonotum and scutellum covered, in part, with white micropubescence; hairs of vestiture white; 12 long, uniform dorsocentral bristle long and white; two white notopleural bristles; two white intraalar bristles; three white scutellar bristles; anatergites with white micropubescence and white, long, fine, mesepimeral bristles. Wing hyaline; veins brown, lighter proximal to wing border. Coxa with white micropubecence; front coxa covered with abundant pilosity, more abundant in front side. Femur and tibia brown, tarsus lighter; strong white bristles on tibiae and tarsi, mixed with long white hairs; four white bristles on external sides of hind femur, distributed in pairs, one pair proximal position other distal. Abdomen covered by white micropubescence, with abundant, short, white, fine, hairs, scattered on distal part of tergites, these are longer on second tergite and its length decrease toward distal tergites; three white bristles laterad on first tergite. Male genitalia (Fig. 17F and 17G) light brown with abundant white, reclinated hairs; hypandrium curved, with two golden, yellow, shiny spines on apex, its length is $1 / 3$ the length of hypandrium. Aedeagus (from a paratype) as in Fig. 28A.

Allotype. Female: similar to male. Ovipositor (Fig. 18A) with light brown spines. Spermatheca (from a paratype) as in Fig. 18B.

Etymology: the name leucotrica, refers to the white or very light brown color of all hairs and bristles on head, body and legs.

Measurements of holotype: total length: 8.5 $\mathrm{mm}$. Wing length: $6.25 \mathrm{~mm}$. Similar measurements in Allotype and paratypes.

Material examined: 23 specimens. $10^{\circ}$ Holotype, 1 \& Allotype, 9 ơ, 4 \&, 5 no genitalia paratypes: Chile. Atacama Prov. $70 \mathrm{~km} \mathrm{~S}$

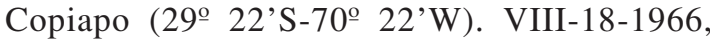

M.E. Irwin-E.I. Schlinger colls. 1 \&, 2 no gen. paratypes: Chile. Atacama Prov. 50-60 km S, 500-600 m, VIII-24-1966, M.E. Irwin-E.I. Schlinger colls.

Geographic distribution: as in Fig. 31D.

Discussion: this species differ from any other species of the genus in having all hairs and bristles white or very light brown. The 23 specimens of the type series present the same characteristics. This general white vestiture, strongly contrast with the dark color of integument. There are another species which has abundant white pilosity, T. asiliformis (Wulp), but also have black and dark brown hairs and bristles. From the collecting area of T. leucotrica, Atacama, $27^{\circ} 22^{\prime} \mathrm{S}-70^{\circ} 20^{\prime} \mathrm{W}$ an extremely dry desert of northern Chile, there are limited samples of asilids.

Tillobroma magellanica (Artigas) (Fig. 19A$19 F, 28 E, 31 C)$

Hypenetes magellanicus Artigas, 1970:124. Chile.

Tillobroma magellanica (Artigas). Artigas \& Papavero, 1991:26 (n. comb).

Holotype: male. Cerro Guido, Magallanes, Feb. 11, 1957, Cekalovic coll. Deposited in Museo de Zoología de la Universidad de Concepción (MZUC-UCCC). Seen. Right antenna lacks first flagellomere; front and middle legs separated from the body, glued to the pin.

Diagnosis: body and legs black, with disperse gray micropubescence on thorax and abdomen. Antennae with scape and pedicele dark, with white hairs and bristles; first flagellomere (Fig.19A) black, stalk 1/3 the length of the flagellomere. Facial gibbosity with gray dull micropubescence; mystax with homogeneous long, thick, black bristles and few white bristles on oral border. Pronotum with hairs and bristles white, mesonotum with black bristles; scutellum with bristles on posterior border, micropubescence and, bristles on disc black. Pleuron with fine, white hairs; katatergite with white bristles. Coxa with white bristles; hind femur without spiny bristles on ventral latero-ventral part, the long hairs are white. Front tibia reddish-brown, with mixed long reddish and black bristles, long hairs are white; bristle of medium length, as long as the basitarsus. Hind tibia with most of the hairs long and white; posterior hairs of 
moderated length; bristles mostly black. Abdomen with first tergite with black and white bristles; tergites with gray micropubescence; tergites 4-7 without reddish reflections. Wings uniform, hyaline, without spots; veins light brown. Male genitalia (Fig. 19B-19D), reddish-brown; hypandrium shorter than epandrium, attenuated at apex and curved gently downward, with two yellowish, sharp spines parallel and in almost full contact along its extension, these spines are as long as the hypandrium; gonopod reddish-brown, with a curved process directed inward; cercus middle sized, bent from mid in straight angle; edeagus as in Fig. 28E.

Female: similar to male. Ovipositor as in Fig. 19E; spermatheca as in Fig. 19F.

Measurements: total length: 7.8-9.2 $\mathrm{mm}$. Holotype: $9.5 \mathrm{~mm}$. Wing length: $6.5-7.1 \mathrm{~mm}$. Holotype: $7.0 \mathrm{~mm}$

Material examined: 10 specimens: 2 o", 3 \% , Chile. Magallanes, Cerro Guido, 11-II-57, Cekalovic coll.; 1 \%, [Chile], Palena, Futalelfú [X Región], 28-I-87, Peña coll.; 2 ơ, 1 no gen., Magallanes, L.[Laguna] Amarga, Chile, 28-II69, Cerda coll.; 1 \%, Chile, Lonquimay, Res. Nac. Las Nalcas, Marzo 10, 1989, A. AnguloG. Weigert coll.

Geographic distribution: as in Fig. 31C.

Discussion: males are easily separate from other species of genus by the extremely long, parallel, close together spines on hypandrium tip. This spines are as long as hypandrium, much longer than corresponding spines on other species.

Tillobroma nahuelbutae n. sp. (Fig. 20A-20D, $28 F, 31 B)$

Holotype: male, [Chile], Nahuelbuta, Parque Cabrería, 13-I-1978, Dr. Cerda. This specimen is deposited in Museo de Zoología de la Universidad de Concepción (MZUC-UCCC).

Diagnosis: body black with areas of whitish-golden micropubescence. Antenna black, capitulum of first flagellomere elongated, the stalk $1 / 4$ or $1 / 5$ length of capitulum. Tibia black, with proximal 1/6 reddish; front tibia with four thick, reddish bristles on exterior side. Hypandrium pointed, with two middle sized spines, reddish-yellow, almost $1 / 4$ the total length of hypandrium, running parallel in all it extension.
Holotype: head in frontal view: face and front with abundant whitish micropubescence; frontal hairs black; ocellar bristles long and black. Head in side view: facial gibbosity dark, with abundant white micropubescence; mystax black, antenna dark covered by smooth golden micropubescence; first flagellomere (Fig. 20A) slightly pedunculated, stalk is $1 / 5$ the length of capitulum; hairs black on scapo and pedicel; beard white; ventrad proboscis and maxillary palpi with white hairs; postocular lower area covered by white micropubescence and long white dense hairs, and black proclinated hairs on upper part; sides of vertex with black longer and dense hairs. Thorax with areas of golden micropubescence and fine golden hairs, more abundant on prothoracic lobes; thoracic pleuron covered by abundant golden micropubescence; mesosternum with abundant white pilosity; bristles on katatergite, black, straight in basal $2 / 3$ and helicoidal toward tip; mesonotum with disperse areas of golden micropubescence; dorsocentral lines brown, well marked; scutellum black with alternated areas of white and golden micropubescence; six pairs of black dorsocentral bristles, postsuturals are two and half times longer than presuturals; two intraalar black bristles; seven postalar black bristles; four black scutellar bristles; anatergites covered by abundant silver micropubescence. Vestiture of coxa similar to thoracic pleuron; white hairs on coxae are more abundant on sides of front coxae; vestiture on front tibia, similar to coxa; femur reddish on basal $1 / 5$ and dark on apical $4 / 5$; tibia with remarkable large, reddish, bristles, mixed with few black bristles; hind femur with four reddish bristles on external sides, distributed at similar intervals. Wings hyaline, veins light brown. Abdomen shiny black, with faintly white, triangular spots on sides of tergites, continuing as a line along the posterior border; first tergite with long, white disperse hairs on sides. Genitalia (Fig. 20B and 20C), reddish-brown, covered with strong, reclinate, black hairs; hypandrium base almost as wide as long, apex curved in $90^{\circ}$, with two brown spines $1 / 5$ the length of hypandrium, aedeagus (from a paratype) as in Fig. 28F.

Allotype. female, similar to the male. Ovipositor as in Fig. 20D.

Measurement. total length: 7.5-10.8 mm. Holotype: $10.8 \mathrm{~mm}$. Wing length: 5.6-7.5 mm. Holotype: $7.5 \mathrm{~mm}$. 
Material examined: six specimens. $10^{\circ}$ Holotype, [Chile], Nahuelbuta, Parque Cabrería, 13-I-1978, Dr. Cerda; 1 ㅇ Allotype, 1 ơ paratype, Cerros de Nahuelbuta, Angol, Chile, 660 m, 30-nov-1956, D.S. Bullock coll.; 10 " paratype, Cerros de Nahuelbuta, Angol, Chile, 660 m, 1-Dc-1956, D.S. Bullock coll.; 1 o paratype, Fdo. Tres Pinos, Nahuelbuta, Feb11-1966, O. Fétis coll.; 1 o" paratype, Chile, Sierra de Nahuelbuta W of Angol, 1200 m, 1-351, Ross \& Michelbacher leg.

Geographic distribution: as in Fig. 31B.

Discussion: the specific name refers to type locality: Cordillera de Nahuelbuta. This species is distinguished from other species of genera by the length of post suturals bristles wich is about two and half times longer than presuturals; the short hypandrium where its length is almost the same as the width of it base, and the apical spines, whose length is $2 / 3$ the length of hypandrium (Fig. 20C).

Tillobroma obtusa (Engel) (Fig. 20E-20G, 30E)

Hypenetes obtusus Engel, 1929:472; Hull, 1962: 154. Bolivia. Tillobroma obtusus (Engel). Artigas \& Papavero, 1991:26 (n. comb.).

Type: male. Type locality: Bolivia, Cordillera de Buena Vista, S. of Cuevo [Cuervo ?], VII.26. Not seen. Deposit unknown.

Diagnosis: head with sides of facial gibbosity shiny black; mystax with black bristles of similar length and thickness, in some, there are at most four white bristles near de oral border; first flagellomere (Fig. 20E) reddish-dark, scape and pedicel with white and black hairs. Pronotum with fine white hairs and bristles. Dorsocentral bristles black, scutellum with black bristles on posterior border, disc with golden brown micropubescence, no hairs. Pleuron with fine black hairs; katatergite with black bristles. Coxa with white hairs. Femur black, unicolor, no spiny bristles, or with three bristles on ventral or laterad-ventrad side, hairs long and black. Front tibia brown, with long, reddish bristles and long white hairs, the longer bristles as long as the basitarsus; middle tibia with long bristles longer than basitarsus. Hind tibia with black bristles; tarsal bristles black. First abdominal tergite with black and white bristles; tergites without or with little micropubescence, appearing shiny black with lateral spots; borders of tergites with micropubescence, contrasting with the dark color of integument. Wing with basal half (male) milky white, the rest brown, fumose, with well defined spots, specially a dark brown stigmal spot on base of $\mathrm{r}_{1}$; veins fuscate. Male genitalia (Fig. 20F and 20G) reddish-brown; hypandrium attenuate from base, pointed, with two small parallel, reddish-brown spines; hypandrium bent downward in straight angle from the mid of its length; gonopod globular, with a short rounded process directed backwards and inward; epandrium slightly darker than hypandrium, extended it does not reach the tip ofhypandrium; bristles on genitalia mostly black; cerci large, recurved upward and slightly frontward.

Female: not studied. Female mentioned in material examined, is of uncertain identification.

Measurements: total length: 11.0-11.5 mm. Wing length: 8-8.3 mm.

Material examined: three specimens. one ? (bad shape), Brasil, S. Paulo, S. Amaro, 45, J.Lane coll; $1 \sigma^{\prime \prime}$, Sao Paulo, H. floresta, Agosto 1944, Ramalho; 1 o", Curitiba, Brasil, VI-44, R. Hertel. Material deposited in the Museo de Zoología de la Universidad de Concepción (MZUC-UCCC)

Geographic distribution: Bolivia, Argentina, Perú (original information). Brasil: São Paulo and Curitiba (new localities). Fig. 30E.

Discussion: Engel, when describing the species, indicates Hermann as the author: "Hypenetes obtusus Herm. in. litt. spec. nov". Nevertheless, authorship should be given to Engel for presenting the first full description. There is no posterior references to Hermann concerning this species. Artigas \& Papavero, 1991: 26, accepted Engel as the author, and formed a new combination, placing the species in the genus'Tillobroma. It is well placed in this genus, where males (not females according Hengel) have wing with basal half of base milky white. This feature is known to be shared with leucoptera n.sp. (Chile) and spinipes $\mathrm{n}$. sp. (Argentina). In spinipes, the milky color is weak. T. obtusa has a well defined stigmal spot (base of $\mathrm{r}_{1}$ ), as it is observed in South African species of the genus Hypenetes Loew, sister genus of Tillobroma. No females where in condition to be studied in this work. 
Tillobroma punctipennis (Philippi) (Fig. 21A$21 G, 27 A, 31 E)$

Clavator punctipennis Philippi, 1865:699, pl. 26, Fig. 31, 31A-31B; Schiner, 1868: 159, Chile.

Hypenetes punctipennis (Philippi). Bromley, 1932: 264 (n. comb.); Stuardo, 1946: 80; Hull,1962:154; Artigas, 1970:124 (a neotype is designate).Tillobroma punctipennis (Philippi). Artigas 7 Papavero, 991:26, n. comb.

Type: lost. A neotype was designate by Artigas, 1970.

Neotype: male. [Chile] Pichinahuel, Arauco, 1,100 m. Marzo 26/28-1954, L. Peña. Deposited in Museo de Zoología de la Universidad de Concepción (MZUC-UCCC). Seen. Missing parts: first flagellomere of left antenna; front left leg (except coxa); front right tarsum; middle left tibia and tarsum; right wing. Left wing is separate from the body and pinned under the specimen.

Diagnosis: scapo and pedicel dark, hairs and bristles mixed white and black; stalk of first flagellomere black (Fig. 21A) similar in length to capitulum; mystax with bristles similar in color and thicknes, all black, in some there are three to four white bristles on oral border; sides of facial gibbosity mostly shiny black. Pronotum with white fine hairs and bristles. Bristles on mesonotum long and black, postsuturals more abundant; posterior border of scutellum with black bristles, scutellar disc with micropubescence and fine scattered, long, black hairs; mesopleuron with fine brown hairs; katatergite with black bristles. Coxa with white hairs and bristles; femora and tibiae black; hind femur (Fig. 21G) with six to eigth strong spiny bristles on ventral and latero ventral side of apical half, hairs black; front tibia with long, mixed black and reddish bristles, as long as the basitarsus, longer hairs are black; hind tibia with the longer hairs black, no longer than half the length of basitarsus. Abdominal tergites shiny black with purple reflections and fine white hairs laterad; posterior border with subtriangular spots of gray micropubescence increasing in size on the last three; on dorsal area of tergites there are triangular spots of slightly brown micropubescence; no reddish reflections on last four tergites. Wing of uniform color in both sexes, fuscate, with faintly brown spots, mainly on bifurcation of $\mathrm{R}$
$2+3$ and $\mathrm{R} 4$, veins light brown. Male genitalia (Fig. 21B-21D) reddish-brown; hypandrium slightly exceeding epandria, ends in the shape of a wide tongue, slightly bent downwards, with two short parallel black, spines on apex; gonopods globular, wider than long, with an apical process directed backward, the tip is hornshaped and directed upward; cercus large, bent upward on center in a straight angle.

Female: similar to male. Ovipositor as in Fig. 21E and 21F.

Measurements: total length: 9.5-11.5 mm. Neotype: $11.5 \mathrm{~mm}$. Wing length: 7.1-8.6 mm. Neotype: $7.5 \mathrm{~mm}$

Material examined: 13 specimens: 8 o", 4 \%, 1 no gen.: $10^{\prime \prime}$ Neotype, Chile, Arauco, Pichinahuel, 1100 m, 26/28-III-54, L. Peña coll.; 1 \%, 2 o', 1 no gen. Arauco, Pichinahuel, 1100 m, 26/28-III-54, L. Peña coll.; 1 \%, Chile, Lonquimay, Res, Nac. Las Nalcas, marzo-101989, A. Angulo-G. Weigert coll.; 1 o", Butamalal [IX Región], 20-3-1966, Cekalovic coll.; 1 ơ, L. Angeles [VIII Región], 12-1-57, Jara coll.; 1 o', Lonquimay, 6/21-Feb-62, L. Peña coll.; 1 \&, Nahuelbuta, C. Coimallín, 28/ 29-III-1980, J. Artigas coll.; $10^{\circ}$, Cord. Parral, Fdo. Malcho, 6-enero-57, L. Peña coll.; 1 \%, Prov. Nuble, Refugio Las Cabras, Cord. Chillán, 1500 m, 28-3-1968, L.E. Peña coll.; 1 ơ", Las Trancas, Cord. Nuble, 9/11-3-52, L.E. Peña coll.

Geographic distribution: this is the type species of Clavator Philippi (preoc. Mollusca) and subsequently of Tillobroma Hull. The most striking character is the presence in hind femora of six to eigth strong spiny black bristles on ventral and lateroventral sides on apical half. Share this character with fulvicornis (Macquart) from Brasil, from which it separate by the color of first flagellomere: reddish in fulvicornis and black in punctipennis. This character also is shared with spinipes n.sp. from Argentina, from which separate by the hind femoral bristles: six to eigth black spiny bristles in punctipennis, and eigth to 10 whitish yellow bristles in spinipes, and by the male wing color, which in punctipennis is uniform but in spinipes the basal half is milky white. Also in spinipes, bristles on katatergite are white and in punctipennis black. Another characteristic to separate punctipennis from spinipes is the color of tibial long bristles, where in front and middle tibiae are totally or 
partially reddish and in hind tibiae are all black in punctipennis and in spinipes the color is the same in all tibiae.

Tillobroma purpurea $n$. sp. (Fig. 22A-22G, 28B, 32A)

Holotype: male and Allotype female, Santiago Prov. Chile, Quebrada de la Plata, Malaise, IX-19-1966, $775 \mathrm{~m}, 33^{\circ} 30^{\prime} \mathrm{S}-70^{\circ} 55^{\prime}$ W, M.E. Irwin. Deposited in Museo de Zoología de la Universidad de Concepción (MZUC-UCCC).

Diagnosis: body black, with golden micropubescence in mesonotum and gray micropubescence on laterad abdomen. First flagellomere dark brown, strongly pedunculate; remarkable purple reflections on sides of facial gibbosity. Femora black, tibiae brown with darker bristles. Wing hyaline with several brown spots. Males genitalia reddish, in part lighter; hypandrium with black apical spines.

Holotype: head in frontal view: face and front with areas of golden and white micropubescence surrounding facial gibbosity; ocellar bristles long, black, strongly divergent. Head in side view: facial gibbosity shiny, with purple reflections, contrasting with the color of mystax and surrounding areas with micropubescence; mystax black, with abundant white, fine hairs in lower half; antenna light brown, lighter on stalk of first flagellomere, capitulum darkened on apex, stalk as long as capitulum (Fig. 22A); scape with white hairs, black on pedicel; hairs on beard, ventral part of proboscis and maxillary palpi white; postocular area fully covered by white micropubescence, with white hairs on lower area and black, proclinate on upper area, more abundant on sides of vertex. Prothorax with areas of golden and white micropubescence and scattered fine, white hairs, more abundant on lobes. Thoracic pleuron with golden micropubescence and few hairs; bristles on katatergite black, straigh on basal $4 / 5$, helicoidal at apex; mesonotum with areas of golden micropubescence, stripes well marked, reduced pilosity black; five pairs of thick, black, dorsocentral bristles, intermingled with abundant, thinner, poorly defined bristles; two black notopleural bristles; two black intraalar bristles; three black scutellar bristles; anatergite covered with golden and white micropubescence, arranged in spots; scutellum with areas of golden and white micropubescence. Wing hyaline, with dark brown spots on defined areas: bifurcation of $\mathrm{R}$ $2+3$ and $\mathrm{R} 4$ and, $\mathrm{R} 4$ and $\mathrm{R} 5$, in $\mathrm{m}-\mathrm{r}$, in $\mathrm{M} 2$ and $\mathrm{m}-\mathrm{m}$, and in CuA1. Coxa similar in color to the pilosity on lower thoracic pleuron; front coxa with abundant golden micropubescence and fine, long, white hairs on anterior part; femur black with abundant fine, erect, disperse, white hairs; hind femur with two light brown spines on external side: one near apex and other near base; tibia light brown, front and middle tibiae with reduced pilosity and mixed brown and light brown bristles on front and middle tibiae; hind tibia with only black bristles. Abdomen dull black, with areas of whitish micropubescence, that hardly can diminish the intensity of black color; few white, short, hairs, more noteworthy and abundant on sides of tergites; three black, long bristles mixed with short, white hairs on sides of first tergite. Genitalia light brown (Fig. 22B-22D) with strong, recline, black hairs and some short white hairs on tip of epandrium; hypandrium strongly curved with two long, black spines on apex, about $1 / 3$ the length of hypandrium; gonopods short, wide, with a wide distal process bent inward and then narrows and curves exteriorly; epandrium reach tip of hypandrium; aedeagus (from a paratype) as in Fig. 28B.

Allotype. Female: similar to male. Ovipositor (Fig. 22E and 22F) brown with gray micropubescence on dorsum of last tergite; five black spines an each acanthophorite. Spermatheca (from a paratype) as in Fig. 22G.

Measurements: total length: 8.3-9.4 $\mathrm{mm}$. Holotype: $8.9 \mathrm{~mm}$. Allotype: $8.2 \mathrm{~mm}$. Wing length: 5.8-6.5 mm. Holotype: $6.3 \mathrm{~mm}$. Allotype: $5.8 \mathrm{~mm}$.

Material examined: 11 specimens: 7 o , 3 \%, 1 no gen.; $1 \sigma^{\prime \prime}$ Holotype, 1 \% Allotype, $4 \sigma^{\prime \prime}$ paratypes, Chile. Santiago Prov. Quebrada de la Plata, 775 m, Malaise, 3330' S - 70ํ5' W. IX19-1966, M.E. Irwin; $10^{\circ}$ paratype, Chile. Santiago Prov. Quebrada de la Plata, Rinconada, Maipú, Malaise, 3331' S- 7047' W, 510 m, VIII-24-66, M.E. Irwin; 1 no gen., 1 \% paratypes, Santiago Prov. Chile, Quebrada de

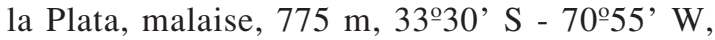
24/26-IX-1966, M.E. Irwin; 1 ᄋ, Hda. Las Palmas de Ocoa, Valpo.22-IX-1960; 1 o $^{\prime \prime}$ paratype, Perales, 1-X-23. 
Geographic distribution: as in Fig. 32A.

Discussion: specific name purpurea refers to the remarkable purple reflection on sides of facial gibbosity. Are characteristic the brown spots on wigs, contrasting with hyaline condition of membrane.

Tillobroma schineri (Artigas) (Fig. 23A-23F, $28 G, 32 C$ )

Hypenetes schineri Artigas, 1970: 124. Chile.

Tillobroma schineri (Artigas). Artigas \& Papavero, 1991:26.

Holotype. Male, Mittel Chile, Rancagua. Schönemann S., 4-97 [1897]. This specimen is deposited in Museo de Zoología de la Universidad de Concepción (MZUC-UCCC). Seen. First flagellomere of both antennae missing.

Diagnosis: first flagellomere (from a paratype, Fig. 23A) elongate, stalk almost as long as the reddish orange capitulum, stalk dark; scapo and pedicel with reddish and black hairs and bristles intermingled. Mystax with black bristles of similar length and thickness, on oral border mixed with fine, white hairs; sides of facial gibbosity shiny black. Pronotum with white hairs and bristles. Mesonotum with abundant black bristles, longer behind transverse suture; humeral calli with fine, short white hairs, contrasting with the condition of remaining hairs and bristles; scutellum with golden gray micropubescence, few fine, scattered, white hairs on disc, five to seven pairs of thick, black bristles on hind border, similar to the ones located on mesonotum posterior to transverse suture. Mesopleuron with fine, brownish hairs; katatergite with black bristles. Front and middle coxa with white hairs, hind coxa with black and white bristles intermingled. Femur black, with abundant long, fine, white hairs; on hind femur four thick bristles (holotype: three reddish and one black), on external side; tibia reddishbrown, with hairs similar to the ones on femur; front and middle tibiae with long, reddish bristles, as long as the basitarsus; in middle tibia, could be also on interior border long black bristles; in hind tibia (Fig. 23E) this bristles are black; tarsus similar in color to tibia, with all bristles black. The brown spots on the wing are faintly, veins light brown. Abdomen black with triangular spots of gray micropubescence on sides; stripe of laterad tergites with micropubescence tending to gold, covering large areas on last three tergites; first abdominal tergite with white hairs and black bristles; next two tergites with fine, white pilosity, the remaining with short bristly hairs. Male genitalia (Fig. 23B and 23C) dark reddish-brown, with black bristles and white bristly hairs; hypandrium attenuated from base, forming a wide, rounded apex, with two short, parallel, black spines, separated at base for a distance similiar to its length; on center of ventral borders of hypandrium, there are a triangular process directed downward; gonopod not globular, from a side view is as long as wide, with a distal subrectangular projection, truncate at apex and directed upwards; at base of this process, there is a small projection spurshaped, black, directed inward; epandrium reaches tip of hypandrium; cerci large, bent in middle, and slightly proclinate; aedeagus (from a paratype) as in Fig. 28G.

Female. Similar to male. Ovipositor (Fig. 23D), reddish-brown, darker on dorsum, subconical, with five black spines on each acanthophorite. Spermatheca as in Fig. 23F.

Measurements: total length: 13.5-16.5 mm. Holotype: $15.5 \mathrm{~mm}$. Wing length: 9.6-11.1 mm. Holotype: $10.6 \mathrm{~mm}$.

Material examined: 17 specimens: $6 \sigma^{\prime \prime}, 10$ \$, 1 no gen. 1 ơ, Mittel. Chile, Rancagua, 4-97 [1897], Schönemann S.; 2 \%, Chile, E.P. Reed; 1 ơ", Chile, Quilpué, III-1927, Dr. Reed; 1 o", Santiago, Maipú, 13-abril-1959, L. Peña coll.; $10^{\prime \prime}$, Chile. Santiago Prov. Maipú, Qbda. de la Plata, $510 \mathrm{~m}$, malaise, 333' ' S - 704' ' W, 4IV-67, N. Hichins O.; 1 \&, Chile, Lagunilla, 12IV-42, E.P. Reed; 1 no gen. La Palma [R.M.], 16-III-68, S. Palma G. coll.; 1 \%, Linares, Catillo, 16/21-3-1972, Exp. Zool. coll.; 1 으, Tranque Orosco, Valpo., 9-IV-1965, L. Marnet M. coll.; 1 o", Lagunillas, S. Ramón, IV-42, E.P. Reed; 1 @, Chile. Santiago Prov., Maipú, Qbda. La Plata, $510 \mathrm{~m}$, malaise, 3331' S70ํำ ' W, 23-III-67, N. Hichins O. coll.; 1 \%, El Salto, Valparaíso, 18-IV-1969, J. Solervicens coll.; 1 \&, Curicó, S.F.; 1 female, T. Cauquenes, Rancagua, 766 m, 22-3-1969; 1 $\sigma^{\prime \prime}$ and 1 \%, Chile, Lagunilla (in copula), 12-IV42, E.P. Reed.

Geographic distribution: as in Fig. 32C.

Discussion: this is the largest species of the genus. It can be recognized by the reddish color 
of the first flagellomere, front and middle tibiae reddish-brown, with abundant, erect pilosity and, the longer bristles orange, some times mixed with black bristles; in hind tibiae, these bristles are all black. In the key presented in this paper, schneri key out near purpurea n.sp., but are easily separate by the size, where purpurea is notably smaller, almost $1 / 2$ the length of schineri; wings of purpurea have fuscate spots, which are not present in schineri; antennae in schineri, mainly first flagellomere, is reddish, while in purpurea is dark. The small black projection, aimed to the center, present at base of apical process in gonopod of shineri, is similar to the one presented in tregualemuensis n. sp.

Tillobroma spinipes $n$. sp. (Fig. 24A-24E, 30B)

Holotype: male. Argentina, Prov. Córdoba, Copina, $1600 \mathrm{mt}$ 11/14-abril-1967. Allotype: Female. Argentina, Mendoza, 2-abril-1967. Coll. L.E. Peña y G. Barría. Both specimens are deposited in Museo de Zoología de la Universidad de Concepción (MZUC-UCCC).

Diagnosis: head, antenna and mystax black. Body black with abundant gray micropubescence. Leg black. Male wing with basal half slightly tinged of milky white. Hind femur with eigth yellowish-white bristles, five of them located in the outside face, its length is similar to corresponding tibia.

Holotype: head in frontal view: face and front with white micropubescence; frontal hairs black, mixed with white hairs; ocellar bristles black, long and divergent. Head in side view: facial gibbosity and mystax black; antenna black with abundant white hairs on scape and pedicel; first flagellomere (Fig. 24A) with the stalk $1 / 3$ the length of capitulum; beard white; fine white hairs on ventrad proboscis and on maxillary palpi; postocular area covered by white micropubescence and abundant fine white hairs, mixed with thicker (bristly) white hairs proclinated at tip; postocular bristles black, strongly proclinated. Prothorax covered by white micropubescence and fine white hairs, more abundant on prothoracic lobes, giving a silver look. Thoracic pleuron with abundant areas of whitish-gray micropubescence and few fine white hairs; white bristles on katatergite; mesonotum with white micropubescence and strong, opistoclinate, black bristles; dorsocentral stripes well defined; dorsocentral bristles black, poorly defined, longer and thicker near the scutellum, mixed with few white hairs; three black notopleural bristles; two black intraalar bristles; four black postalar bristles, mixed with four fine black hairs of equal length; three pair of black scutellar bristles; anatergite covered by white micropubescence. Leg complete black, except tibio-femoral articulation, which is brown; femur covered by abundant fine erected white hairs, less abundant on internal face; hind femur with eogth-10 yellowish-white bristles, at least five on external face, not counting the four periapical bristles, two of which are dark brown; these bristles strongly contrast with the black color of femoral tegument; the front ones are covered by abundant white micropubescence and fine long, white hairs. Wing with base, at least $b r, b m, c u P$ and $a l$ cells, weakly tinged of milky white, remaining totally hyaline; veins light brown. Abdomen black, with abundant areas of white micropubescence and fine, long, white hairs, more abundant on sides of first tergite. Genitalia (Fig. 24B and 24C), light brown, with fine white hairs, reclinated from basal third; hypandrium curved on apex, with two yellowish brown, divergent spines; gonopod globular, wider than long, with a short, flattened, rounded apical process. Cercus small, only slightly curved up at tip.

Allotype: female. Similar to male. Last two abdominal segments shiny dark brown, almost black. Ovipositor (Fig. 24D), with five pairs of shiny black spines on acanthophorites. Wing hyaline, without spots. Spermatheca (from a paratype) as in Fig. 24E.

Measurements: holotype, total length: 12.1 $\mathrm{mm}$. Wing length: $7.6 \mathrm{~mm}$. Allotype and paratypes of similar measurements.

Material examined: five specimens: $4 \sigma^{\prime \prime}, 1$ ㅇ. $10^{\prime}$ Holotype Argentina, Prov. Córdoba, Copina, $1600 \mathrm{mt}$. 11/14-abril-1967, 1 o' paratype Argentina, Prov. Córdoba, Copina, 1600 mt, 11/14-Abril-1967, L.E. Peña-G. Barría colls.; 1 ㅇ Allotype, Argentina, Mendoza, 2-4-1967, L.E. Peña-G. Barría colls.; $2 \sigma^{\prime \prime}$ paratypes, Argentina, Córdoba, Copina, 1600 mt, 14-Abril-1967, L.E. Peña-G. Barría colls.

Geographic distribution: as in Fig. 30B.

Discussion: the specific name refers to the 8-10 thick, white bristles present on hind femora, contrasting with the black color of 
integument. This species is distinguishable by the slightly milky white color at basal half of male wings; legs are uniform black or deep dark-brown, with all bristles black or darkbrown, except hind femur, where it can have one or two whites bristles on each leg, and the presence of only white bristles on katatergite. The milky condition of basal male wings, is sheared with leucoptera and obtusa, but in those species the white color is more intense. The white color of bristles on katatergite is sheared with asiliformis, huasquina, leucotrica, magellanica and tregualemuensis. These species can easily be separated by the given key.

Tillobroma tregualemuensis n. sp. (Fig. 25A$25 F, 27 H, 32 B$ )

Holotype: male. Tregualemu, 24 marzo 1967, Moyano coll.

Allotype. Female. Tregualemu, 24 marzo 1967, Cekalovic coll. Both specimens are deposited in the Museo de Zoología de la Universidad de Concepción (MZUC-UCCC).

Diagnosis: body with abundant areas of golden and gray micropubescence. First flagellomere with stalk black and reddish capitulum. Mystax black. Tibia light brown, contrasting with the shiny black femora. Wing hyaline, without spots. White pilosity on abdomen. Male genitalia yellowish-brown; hypandrium wide, with two short spines of same color; gonopod longer than wide, with a thin apical process, slightly undulate, directed backward, on its base there is a short, acute, spiniform, black projection, directed inward.

Holotype: head in frontal view: face and frons black, with areas of white micropubescence, more abundant on side of facial gibbosity; ocellar bristles white, long and slightly divergent, mixed with black bristles. Head in side view: facial gibbosity black, but do to the presence of intense white micropubescence, it looks silvery; mystax black, with few white hairs on ventral area; antenna dark, scape with white hairs, pedicel with intermingled white and black hairs, stalk of first flagellomere (Fig. 25A) dark, capitulum reddish; beard white; ventral part of proboscis and palpus with fine white hairs; postocular area with white micropubescence, white hairs on lower area and white and black hairs intermingles, slightly proclinate, in upper part, more conspicuous on sides of vertex. Prothorax with white micropubescence and fine white long hairs, more abundant on prothoracic lobes. Thoracic pleuron with abundant areas of silver micropubescence; fine, white hairs on pleuron and sternopleuron; bristles on katatergite white; mesonotum and scutellum with areas of silver and golden micropubescence, more conspicuous the golden ones on sides of central stripes; anterior part of mesonotum with black opistoclinate hairs; six to eigth pairs of black dorsocentral bristles; two notopleural bristles, three intraalar bristles, five postalar bristles, mixed with white hairs of similar length, four pairs of scutellar bristles; anatergite covered with white micropubescence. Coxa black with areas of gray micropubescence and long, fine white hairs, more abundant on frontal area of front coxa, and on sides of middle and hind coxa; femur dark, with abundant fine, long, hirsute, white hairs; middle and hind femora (Fig. 25E) with a pair of short, yellow spines on external side, equidistant form both ends; tibiae light brown, contrasting with the dark color of femora; front and middle tibiae, with golden-brown bristles, mixed on apex with few black bristles; hind tibia with black bristles mixed with light-brown bristles. Abdomen black with areas of golden gray micropubescence, more abundant on sides of tergites; first tergite covered with abundant white pilosity, longer and more abundant on sides. Genitalia (Fig. 25B and 25C), light brown, similar in color with tibia, with white hairs; hypandrium wide and slightly curved down, with two short spines of similar color on apex. Gonopod short and wide, with a thin, digitiform process, gently undulated and directed backward; at base of this process there is a black spiniform, projection, directed inward; cercus large, bent on middle and gently proclinate. Aedeagus (from a paratype) as in Fig. 27H.

Allotype. Female: similar to male. Ovipositor as in Fig. 25D. Spermatheca (from a paratype) as in Fig. 25F.

Measurements: total length: 8.1-11.6 mm. Holotype: $19.1 \mathrm{~mm}$. Wing length: $6.5-7.9 \mathrm{~mm}$. Holotype: $7.9 \mathrm{~mm}$.

Material examined: 16 specimens: $6 \sigma^{\circ}, 8$, 2 no gen. $10^{\prime \prime}$ Holotype, $2 \%, 1 \sigma^{\prime}$ and $1 \%$ (copula), 1 no gen. paratypes, Tregualemu, 24 
marzo 1967, Moyano coll.; 1 ㅇ Allotype, 2 \%, 1 $\sigma^{\prime}$ and 1 \& no abdomen (copula) paratypes, Tregualemu, 24 marzo 1967, Cekalovic coll.; 1 ơ paratype, Tregualemu, 15 marzo 1967, Cekalovic coll.; 1 ơ, 2 \%, Tregualemu, Feb. 1972, H. Moyano coll.paratypes; 1 o", Tregualemu, 15 marzo 1967, Moyano coll. paratype.

Geographic distribution: as in Fig. 32B.

Discussion: the name of the type locality, Tregualemu, gives it name. Two pairs were collected in copula. This allowed the authors to recognize the females. This species is close to magellanica $\mathrm{n}$. sp. from which it can be separate by the color of front tibial bristles, which are mostly black in magellanica and mostly yellowish-white in tregualemuensis and, for the length of the spines on hypandrium apex, which are extremely long, as long as the gonopod and it apical process together. In magellanica and tregualemuensis those spines are short, as long as half the length of the gonopod process. The small black projection, born at base of gonopod and directed inward, is similar to the one found in schineri.

Tillobroma valentinei (Artigas) (Fig. 26A-26G, $27 C, 32 D)$

Hypenetes valentinei Artigas, 1970: 124. Chile.

Tillobroma valentinei (Artigas). Artigas \& Papavero, 1991: 26 (n. comb.).

Holotype: male. Coquimbo Los Molles, 1,300 m, 7/10-nov-1961, Peña coll. This specimen is deposited in Museo de Zoología de la Universidad de Concepción (MZUC-UCCC). Seen. The first flagellomere of both antennae are missing; the abdomen is separated from the body and glued to the locality label.

Diagnosis: body with abundant gray and golden micropubescence in small areas of mesonotum. Head black with all anterior bristles, mystax and verticals bristles black. Postocular hairs snow-white, contrasting with the black bristles. Antennae totally black; first flagellomere (Fig. 26A) with capitulum twice the length of stalk. Mesonotum with strips marked with gray micropubescence, alternating with stripes of dark golden micropubescence; mesonotal bristles black, presutural shorter than posterior; scutellum with gray micropubescence and scattered black hairs on disc, on hind border there are four pairs of long black bristles mixes with some hairs of similar color. Femur and tibia black; anterior and middle femora with long white hairs, hind femur with long black hairs. Front tibia with the longest reddish bristles shorter than basitarsus; middle tibia with the longest bristles black and longer than basitarsus; hind tibia (Fig. 26F) with bristles shorter than basitarsus. Abdomen black, with large areas of whitish micropubescence on sides of tergites, forming a line on posterior border of each tergite; first abdominal tergite with white hairs and black bristles on sides; dorsum of tergite with thick black, short pilosity, gently reclinate. Male genitalia (Fig. 26B to 26D) light reddish-brown; hypandrium strongly curved down in $90^{\circ}$ degree angle (Fig. 26B), apex form a thin, flat lamella with the tip expanded an bilobulated, without spines (Fig. 26C and 26D). Gonopod globular, subspheric, with and apical broad projection, flattened on dorsum, with apex compressed, directed gently directed inward. Cercus small, curved al apex. Aedeagus as in Fig. 27C.

Female: similar to male. Ovipositor (Fig. 26E) reddish-brown, darker on dorsum, with five pairs of reddish-brown spines. Spermatheca as in Fig. 26G.

Measurements: total length: 10.6-14.4 mm. Holotype: $1.8 \mathrm{~mm}$. Wing length: 7.6-9.4 mm. Holotype: $8.1 \mathrm{~mm}$.

Material examined: 149 specimens: $105 \sigma^{\circ}$, 41 \&, 2 no gen. $1 \sigma^{*}, 1$ @ Coquimbo, Río Los Molles, 1300 m, 7/10-nov-1961, L.E. Peña coll.; 1 ơ, 1 \%, Aconcagua, Río Blanco, 5/8-121961, L.E. Peña coll.; 1 ơ, 1 only thorax and legs, Estero Canela, Puerto Oscuro, Coquimbo, 24-X-61, L.E. Peña coll.; 1 \&, Chile. Nuble, 40 $\mathrm{km}$ of San Carlos, XII-23-1950, Ross \& Michelbacher; 2 o", Valle Los Piuquenes, Aconcagua, Chile, 7/12-II-64, L.E. Peña coll.; 1 ơ, Carén, Dic- 14-1963, L.E. Peña coll.; 1 \&, $1 \sigma^{\prime \prime}$, Hacienda Illapel, Prov. Coquimbo, Chile, 6-900 m (313ㅇ' S-71ํ07' W), X-19-1966, Schlinger-Irwin-Peña; 3 ơ, 2 \%, Til Til, Caleu, 28-11-1982, M. Cerda coll.; 2 o', Til Til, Caleu, 28-11-1982, G. Cerda B. coll.; 2 \%, 1 ơ, Til Til, Caleu, 28-11-1982, J. Cerda B. coll.; 2 ơ, 3 , 1 no gen., Río Teno, $800 \mathrm{~m}$, Los Queñes, Chile, XI-81, L.E. Peña coll.; 3 ơ, Cord. Ovalle, El Manzano, 4-nov-1964, L.E. Peña coll.; 1 \%, Nahuelbuta, Parque Coimallín, 26-I1980, G. Cerda B. coll.; 1 o', Nahuelbuta, Parque Cabrería, 11-1-1978, Dr. Cerda coll.; 3 
ơ, 1 \&, Coquimbo, Hda. Illapel, 600-800 m, 21/ 22-10-1967, L.E. Peña coll.; 1 \&, Petrohué, Llanquihue, 6-II-1968, J. Solervicens coll.; 1 ơ, Coquimbo, Hda. Illapel, 16-nov-1963, L.E. Peña coll.; $2 \sigma^{\prime \prime}, 1$ ㅇ, $1 \sigma^{\prime \prime}$ and 1 ㅇ (in copula) Chile. Coquimbo Prov., Hacienda Illapel, Río Illapel, 600900 m, X-19-1966, E.I. Schlinger \& M. E. Irwin; 1 o', Sn. J. de Maipo, Andes y Santiago, Chile, XII-1979; 1 ㅇ, Caleu, Lo Marín, 23-12-1984, Dr. M. Cerda coll.; 1 ơ, Aconcagua, R. Blanco, 11-nov-1963, L.E. Peña coll.; 1 \&, Chile. Curicó Prov. Fundo La Montaña, Estero la Palma at Río Teno, $6 \mathrm{~km} \mathrm{E}$ Los Queñes, 1-4-1967, M.E. Irwin; 1 \&, Illapel, oct-1978; 1 ơ, $5 \mathrm{mi} \mathrm{W}$ of La Junta, Coq. Chile, XII-7-50, Ross \& Michelbacher; 1 o', Cord. Ovalle, El Manzano, 4-nov-1964, L.E. Peña coll.; 1 o', Vegas del Flaco, $1350 \mathrm{~m}$, Talca (Andes), Chile, XI-1969, L.E. Peña coll.; $1 \sigma^{\prime \prime}$, Talca, Pencahue, 26-X-1968, V. Pérez coll.; 1 ơ, Prov. Talca, Paso Pehuenche, 2400 m, 16enero-1968, L.E. Peña coll.; 1 no gen., San Fabián de Alico, Dic.-31-1966, P. Casals coll.; 4 ơ, 6 \%, Alcahuaz, Elqui-Vicuña, Chile, XI/ XII-1990, L.E. Peña coll.; 13 ơ, 7 ㅇ, El Pangue, Vicuña, 27-XII-1989, L.E. Peña coll.; 6 ơ', Chile. IV Región, Alcahuaz, Vicuña, Prov. Elqui, XI/XII-1990, L.E. Peña coll.; 5 ơ, Chile. IV Región, Céspedes, Illapel, 1150 m, 15-101994, A. Ugarte coll.; 1 o', Chile. Vicuña, El Pangue-Elqui, 10-12-1989, L.E. Peña coll.; 1 ๙", Chile. IV Región, Vicuña-Elqui, 20-101991, L.E. Peña coll.; 5 ơ, IV Región, Céspedes 1100 m, Illapel, Prov. Choapa, 13/1410-1994, A. Ugarte coll.; 1 \$, IX Región, Pino Hachado, 1700 m, Lonquimay-Malleco, Ene-81994, L.E. Peña coll.; 1 ơ, IV Región, Los Molles, 2600 m, Ovalle-Limarí, oct- 17-1994, A. Ugarte coll.; 1 \$, Reg. Metrop. Prov. Chacabuco, Cuesta La Dormida, oct. 11-1995, A. Ugarte coll.; 2 ơ, 3 IV Región, El Bato, 800 m, Illapel, Choapa prov., oct 12-1994, A. Ugarte coll.; 1 ᄋ, IX Región, Termas de

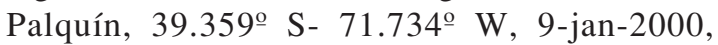
DW.Web; 2 ơ, 5 ㅇ, IV Región, Prov. Choapa, Illapel, Céspedes, 1100 m, oct. 13-1994, A. Ugarte coll.; 16 ơ, 4 \%, IV Región, Céspedes, Illapel (1150 m), 14/15-oct-1994, L.E. Peña coll.; 1 ơ, VII Región, Curicó, Las Tablas, 121994, A. Ugarte coll.; 3 ơ, Chile. Limarí Province: $3.5 \mathrm{~km}$ E Central Los Molles, riparian zone, $4710 \mathrm{ft}, 30.7351^{\circ} \mathrm{S}-70.5676^{\circ} \mathrm{W}$, 17-XI-1997, E.I. Schlinger coll.; 3 0', Chile.
Limarí Province: $3.5 \mathrm{~km}$ E Central Los Molles, riparian zone, $4710 \mathrm{ft}, 30.7351^{\circ} \mathrm{S}-70.5676^{\circ} \mathrm{W}$, 17-XI-1997, D.W.Web coll.; 1 ơ', Chile. Limarí province: $3 \mathrm{~km}$ W Central Los Molles, malaise in riparian zone, $3850 \mathrm{ft}, 30.7457^{\circ} \mathrm{S}-70.6345^{\circ}$ W, 17-XI-1997, M.E. Irwin, E.I. Schlinger, D.W.Web; $1 \sigma^{\prime \prime}$ and 1 \% (in copula), Chile. Limarí Province: $3.5 \mathrm{~km}$ E Central Los Molles, riparian zone, $4710 \mathrm{ft}, 30.7351^{\circ} \mathrm{S}-70.5676^{\circ} \mathrm{W}$, 17-XI-1997, M.E. Irwin.

Geographic distribution: as in Fig. 32D.

Discussion: species male genitalia is unique in the genus because the apex of hypandrium is bent down in straight angle, forming toward the end an expanded spatula with bilobulate hind border (Fig. 26B and C). Females are difficult to separate from $T$. critesi Artigas. The long, reddish front tibial bristles are not longer than the basitarsus in valentinei, while in critesi are long, black or reddish, in occasions mixed, and always longer than the basitarsus. They also differ in the abdomen, wich is black or shiny deep dark-reddish, almost glabrus in critesi, while in valentinei, dorsum has gray micropubescence, triangular spots, and abundant pilosity.

\section{Additional material of Tillobroma}

During the study, the authors examined eight neotropical specimens, identified as Hypenetes, but their identification to specific level was impossible.

Argentina: 1 male, Tucuman. Tafí del Valle. R. Golbach col. 6/12 XII 1947. Identify as Hypenetes asiliformis Wulp by Carrera \&Papavero '62; 1 male (gen. prep.), Pucará. Pcia.[Provincia] Neuquén. Lg. S. Schajovskoy. 15-I-1956; 1 male, Salta. Alturas Amblayo. 3200 m. XII. 86. Fruits.

Bolivia: 1 male, Pongee de Quire. Wm. M Mann. July. Mulford Bio Expl. 1921-22. E.A Pritchard collection 1962 (USNM); 1 male Tatarenda. Chaco. Erlana Nordenskj. Riksmuseum Stockholm as Hypenetes (Tillobroma) obtusus Engel by N. Papavero 1966.

Paraguay: 1 male, Vega. Prov. Itapué. XII54, Dirings. Identify as Hypenetes sp. by Carrera \& Papavero " 62.

Perú: one female, Yacuacocha, (?), Chiquisa. 4100 m. Perú. 13.VII.50. Identified as Hypenetes sp. by Carrera \& Papavaro '62; one male, Lucre Cusco. 5.IV.64.Vuelo. 1018. 
These localities have been not included in the distribution maps.

\section{Phylogenetic analysis}

Table 1 presents the characters and character states for each species of Tillobroma studied (21 species, 10 new species) and for two species of the sister genus Hypenetes Loew.

The cladogenetic analysis found four more parsimonious trees with a length of 241 , a consistency index of 0.35 , a retention index of 0.53 and a re-scaled adjustment of $18.55 \%$. Fig. 29 presents the tree of strict consensus (length of 260, consistency index of 0.32 and retention index of 0.48). The South American species formed a monophyletic clade supported by nine synapomorphies: (1) orange red capitulum of flagellum, (2) a pedicel which length is twice the lenght of the capitulum, (3) weak postocular bristles, (4) black bristles on katatergite, (5) unicolor hind femora, (6) unicolor anterior and hind tibiae, (7) long yellow hairs on front tibiae, (8) apex of hypandrium pointed, and (9) cerci medium size to large, recurved anteriorly. The analysis of the internal group established three notable monophyletic groups. Group (1) magellanica + spinipes + asiliformis + huasquina + leucotricha, with two synapomorphies: 0(2) Chestnut capitulum of the flagellum I, and 14(2) with two to four spiny bristles on the hind femora. Group (2) digitatus + leucoptera with one synapomorphy: 31(1) hypandrium slightly shorter than the epandria. Group (3) aconcaguana + fucosa + nahuelbutae + fucosoides + angulata + valentinei with one synapomorphy: 18(4-5) the longer bristles of front tibiae are reddish black.

The low consistency and retention indices indicate a large quantity of homoplasies that clouds the resolution of the internal group (polytomy).

Characters and character state for the phylogeny and taxonomy of Tillobroma Hull

0. Flagellum, capitulum color: one black; two chestnut-dark; three reddish-orange; four black with red apex and style (flagellum II), or red with black apex and style.

1. Relation capitulum and stem of flagellum I: one similar longitude (Fig. 16A); two stem length one-third or one-fourth the length of capitulum (Fig. 26A); thre stem length twice the length of capitulum (Fig. 11A).

2. Antennites, principal color of hairs and bristles: one all white; two mixed white and black; three only black.

3. Mystax, thickness of bristles: one in upper half ostensibly thicker than in lower half; two all of similar conditions.

4. Mystax, color: one black (at most four white lashes); two mixed white and black; three in upper half black, in lower half white; four white (at most four black bristles).

5. Facial gibbosity, color on laterad: one with micropubescence gray, without shine; two principally shiny black; three with purple glow; four red tegument with white micropubescence;

6. Head, post-ocular bristles: one weak, just barely appear above the upper edge of the eye; two thick and long, slanting forward at the end, passing beyond the upper edge of the eye.

7. Pronotum, hair colors: one white; two mixed white and black.

8. Mesonotum bristles, color: one white; two mixed white and black; three black.

9. Bristles of scutellum edge, color: one white; two mixed white and black; three black.

10. Scutellum disk integument: one with micropubescence; two primarily shiny.

11. Scutellum disk, hairy elements on disk: one without; two with.

12. Katatergite bristles color: one white; two yellow; three black; four mixed black and white.

13. Hind femora integument color: one unicolor; two bicolor lengthwise.

14. Hind femora presence of spiny bristles: one without bristles, except one or two apical; two to four bristels in ventral face; three more than five bristles well noted in ventral-lateroventral face.

15. Hind femora color of long hairs: one white; two yellow; three mixed; four black.

16. Front and posterior tibiae integument color: one unicolor; two transversally bicolor.

17. Front tibiae integument color: one chestnut to chestnut-red; two very dark or black, 
color of corresponding femur not distinguished.

18. Front tibiae color of long bristles: one white; two yellow; three mixed red and black; four black; five red.

19. Front tibiae color of long hairs: one white; two mixed white and black; three black.

20. Front tibiae dominant hair type: one short, fusiform, adjacent to the integument (depressed); two erect, normal.

21. Rear tibiae color of long hairs (principally): one white; two yellow; three black.

22. Posterior tibia hairs length on posterior face: one normal, not longer than one-anda-half times length of the basitarsus; two long, more than two-and-a-half times length of basitarsus and with waves.

23. Posterior tibia bristles color: one white; two red and yellow; three black.

24. Abdominal tergites, integument covering: one with gray micropubescence; two with triangular marks of chestnut-red micropubescence; three black or shiny dark-red without micropubescence (more like balding); four dark, with transparent blue tones and shiny white triangular marks; five with triangular marks of whitened micropubescence.

25. Tergites IV to VII tonalities: one with reddened tones; two without reddened tones.

26. Wing color of basal half: one with no difference; two died a milky white color.

27. Wing color of entire membrane or apical half if base is milky: one hyaline; two smoky-chestnut.

28. Wing marks on membrane: one without marks; two with few weak marks; three with a well-noted coastal mark (stigma); four with several defined marks, mainly on base of some longitudinal veins and near some transverse veins.

29. Wings edge color: one light-chestnut; two dark-chestnut to black.

30. Male genitalia color: one uniform reddened-chestnut; two bicolor (red and black) not uniform; three black.

31. Relation of epandrium-hypandrium extension: one hypandrium slightly shorter; two same length; three hypandrium slightly longer than the extension of the eardrum; four eardrum longer than the hypandrium by half of its length.
32. Hypandrium apex: one obtuse; two pointed; three flattened.

33. Hypandrium apex direction: one more or less straight; two gently curved downwards; three bent brusquely downwards in a straight angle.

34. Hypandrium spines: one without spines; two two short and parallel; three two short and divergent; four two medium sized and parallel; five two medium sized and divergent; six two long and parallel, as long as gonopods, including its distal projection.

35. Hypandrium spines color: one without spines: two yellowish-red; three black; four white.

36. Gonopod in side view: one short, rounded; two with a straight digital process directed posteriorly; three with a sinuous process directed posteriorly; four apical process curves inward.

37. Gonopod color: one chestnut-red: two bicolor red and black; three yellow (or clearer) on back, notable in distal process; four black.

38. Cercus characteristics: one small and more-or-less straight: two medium to large, bent upward in a straight angle on middle; three medium to large, bent and re-curved frontad; four small, bent up gently at tip.

\section{DISCUSSION}

The presence of Hypenetes in both continents is supported by the numerous shared external characters (38 characters, Table 1), with only some minor modifications of the hypandrium, such as number of spines, and of the gonopods, which are the external characters that differentiate both populations. These can be seen in Fig. 1C, 2A, 2B, 7B and 21F. The external similarity of both populations is remarkable, especially the wings, antennae, bristles, mouth apparatus, legs, and general aspect (Fig. 4 and 5A). Consequently, the likelihood of a convergent evolution for two different trunks is discarded (See the character states in Table 1).

Hypenetes Loew in South Africa and Tillobroma Hull in South America (sister genera) is supported by nine synapomorphies given by the phylogenetic analysis, differences 


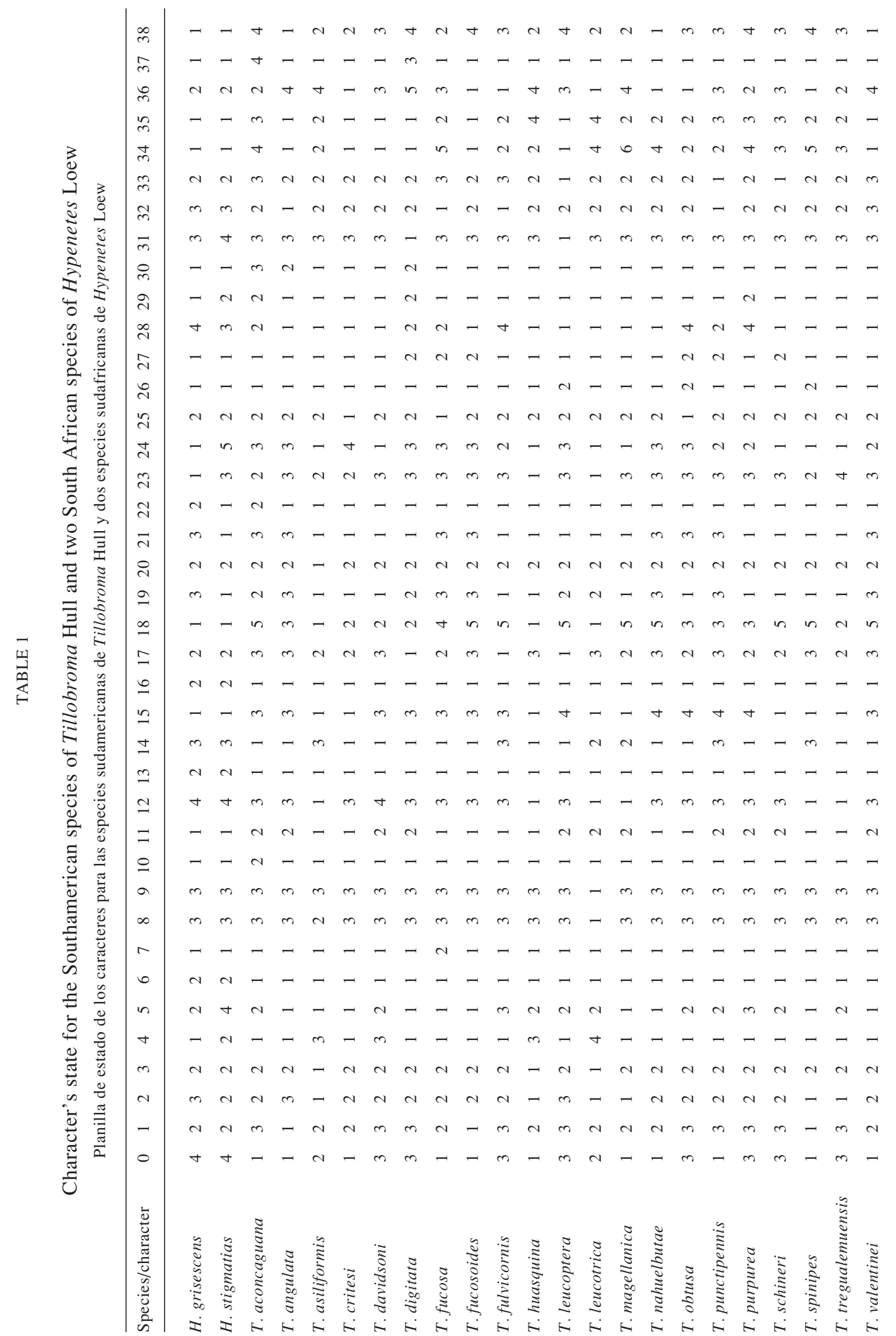




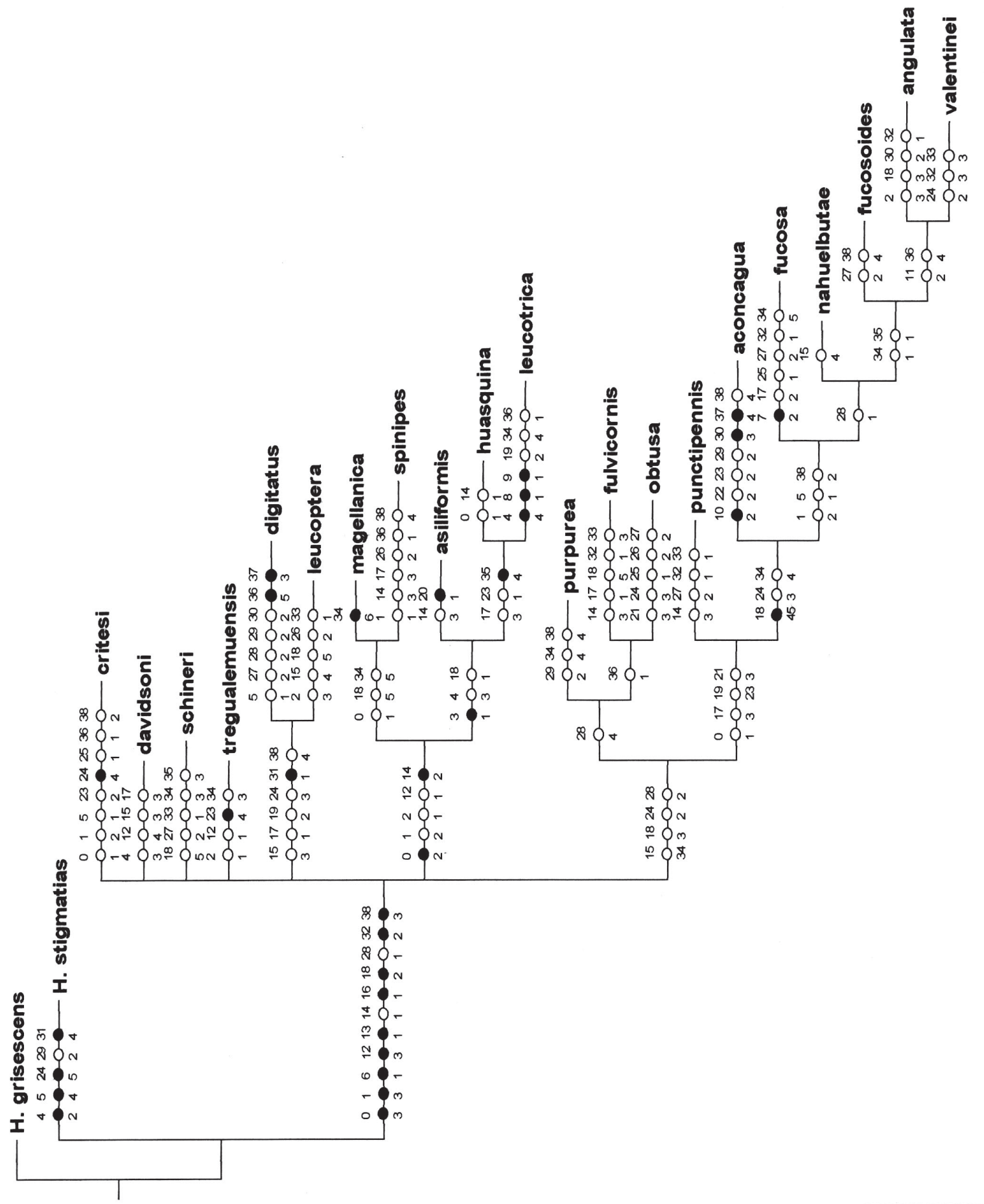

Fig. 29: Filogenetic tree of strict consensus for the South American species of Tillobroma and two South African species of Hypenetes Loew (length 260, consistence index 32, retention index 48). The numbers over the branch indicates the number of character and those under the branch the state of the character.

Arbol filogenético de consenso estricto para las especies sudamericanas de Tillobroma Hull y dos especies sudafricanas de Hypenetes Loew (longitud 260, índice de consistencia 32, índice de retención 48). Los números sobre la rama indican el número del carácter y los bajo la rama el estado de un carácter. 


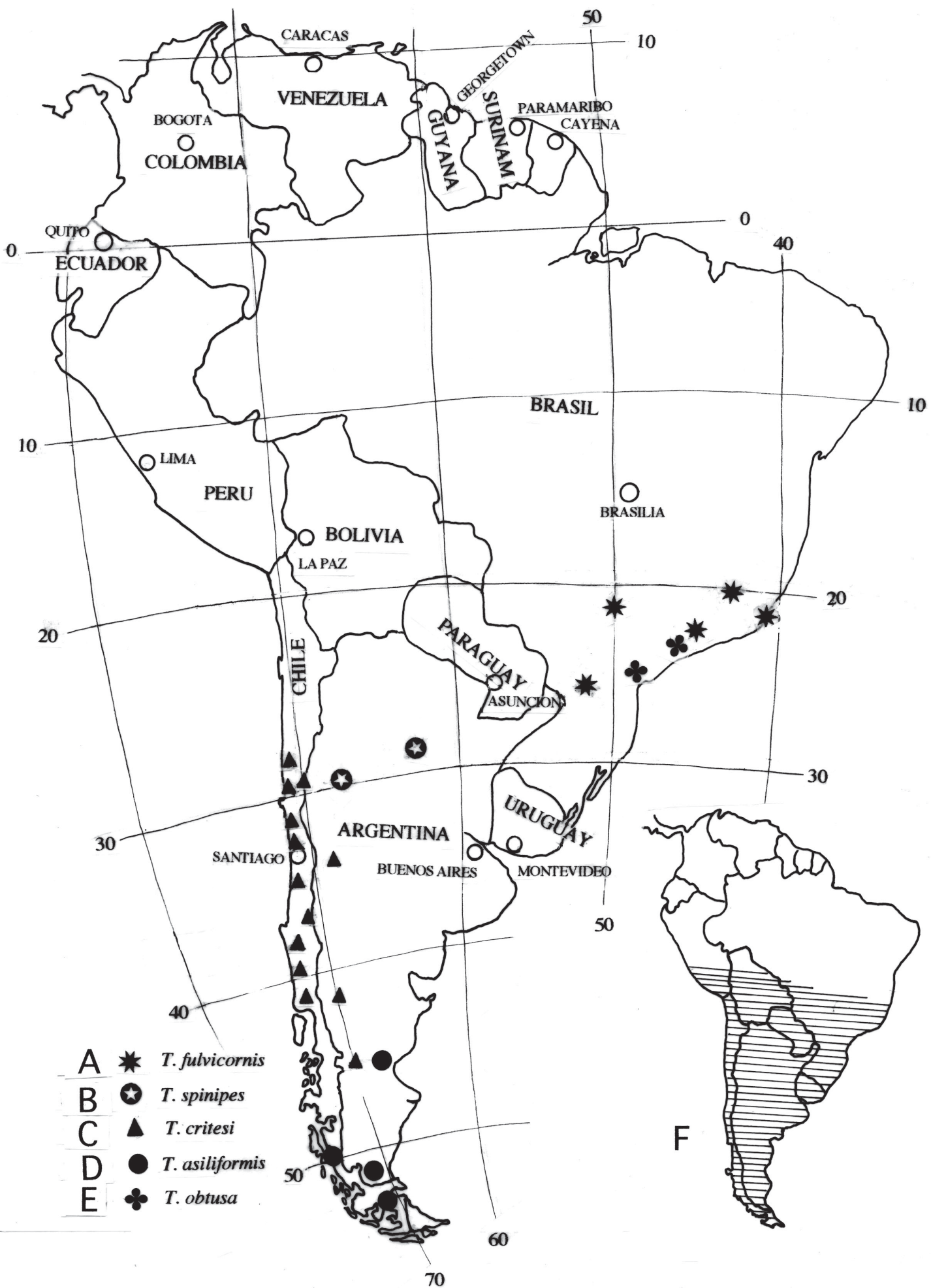

Fig. 30: Geographic distribution of: (A) T. fulvicornis (Macquart); (B) T. spinipes n. sp.; (C) T. critesi (Artigas); (D) T. asiliformis (Wulp); (E) T. obtusa (Engel); (F) Stimated distribution of genus Tillobroma.

Distribución geográfica de: (A) T. fulvicornis (Macquart); (B) T. spinipes n. sp.; (C) T. critesi (Artigas); (D) T. asiliformis (Wulp); (E) T. obtusa (Engel); (F) Distribución estimada del género Tillobroma. 


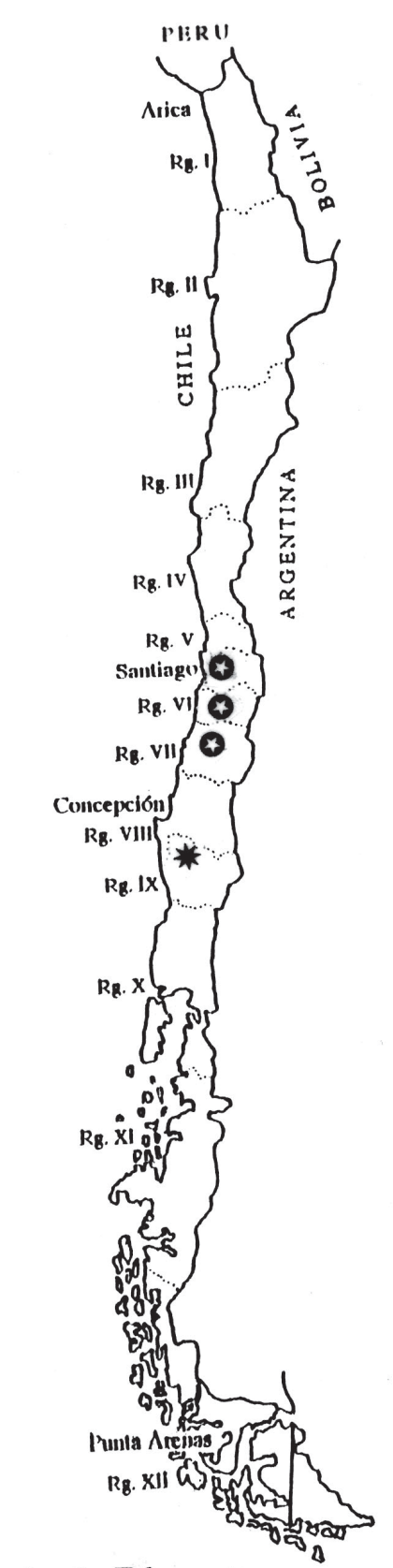

A T. leucoptera

B * T.nahuelbutae

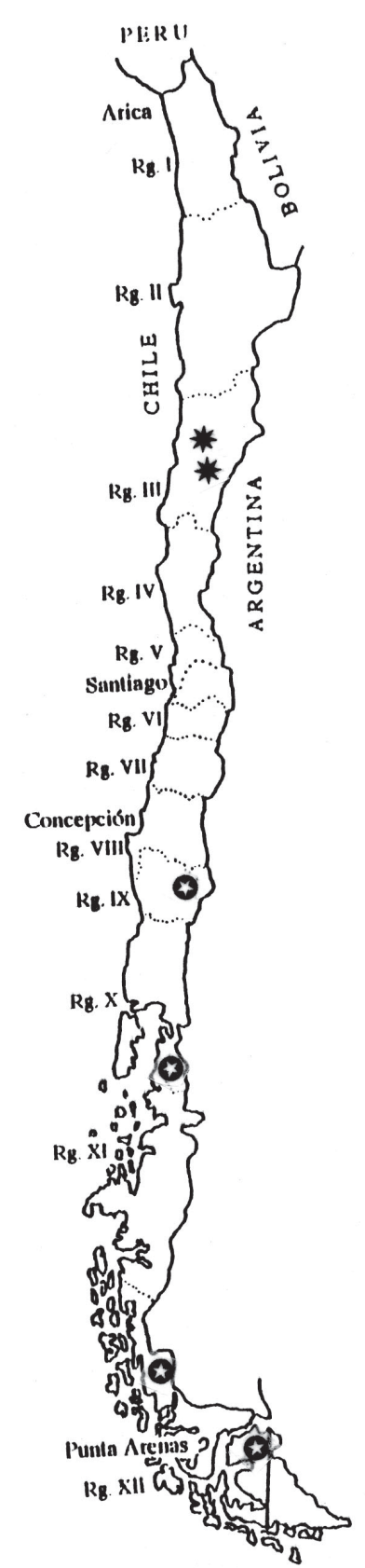

C T.magellanica

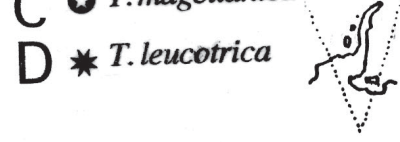

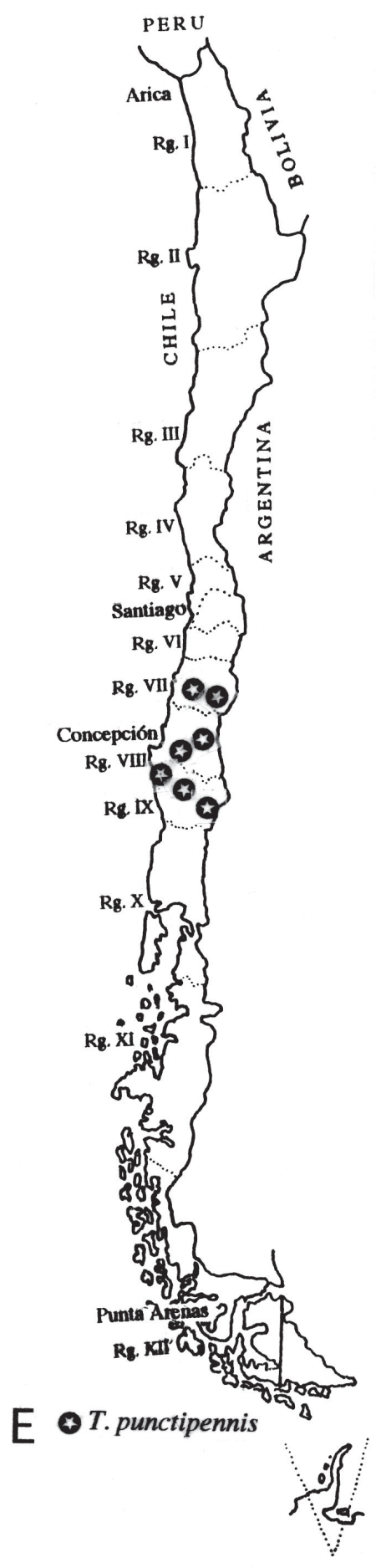

Fig. 31: Geographic distribution of: (A) T. leucoptera n. sp.; (B) T. nahuelbutae n. sp.; (C) T. magellanica (Artigas); (D) T. leucotrica n. sp.; (E) T. punctipennis (Philippi).

Distribución geográfica de: (A) T. leucoptera n. sp.; (B) T. nahuelbutae n. sp.; (C) T. magellanica (Artigas); (D) T. leucotrica n. sp.; (E) T. punctipennis (Philippi). 

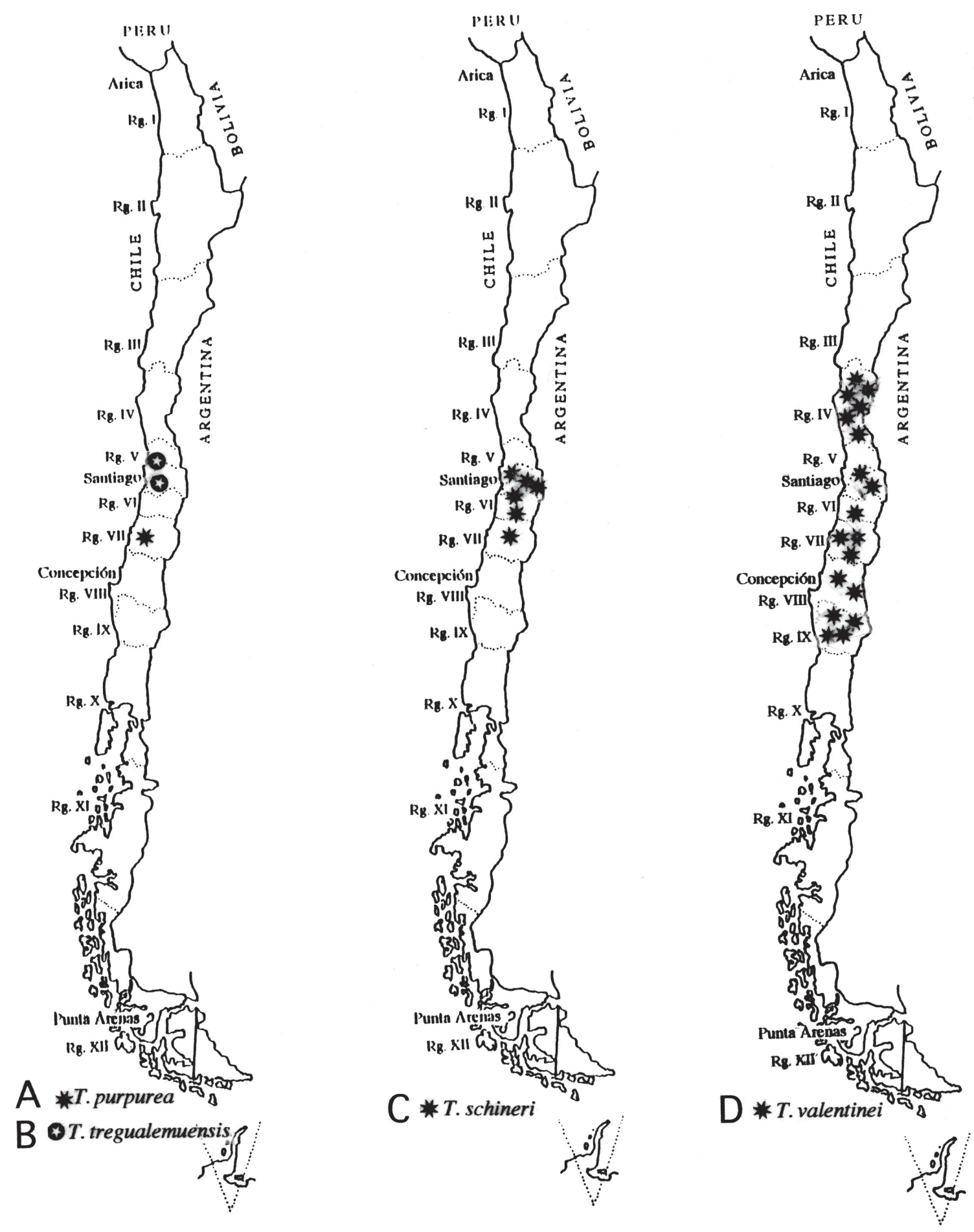

Fig. 32: Geographic distribution of: (A) T. purpurea n. sp.; (B) T. tregualemuensis n. sp.; (C) T. schineri (Artigas); (D) T. valentinei (Artigas).

Distribución geográfica de: (A) T. purpurea n. sp.; (B) T. tregualemuensis n. sp.; (C) T. schineri (Artigas); (D) T. valentinei (Artigas). 


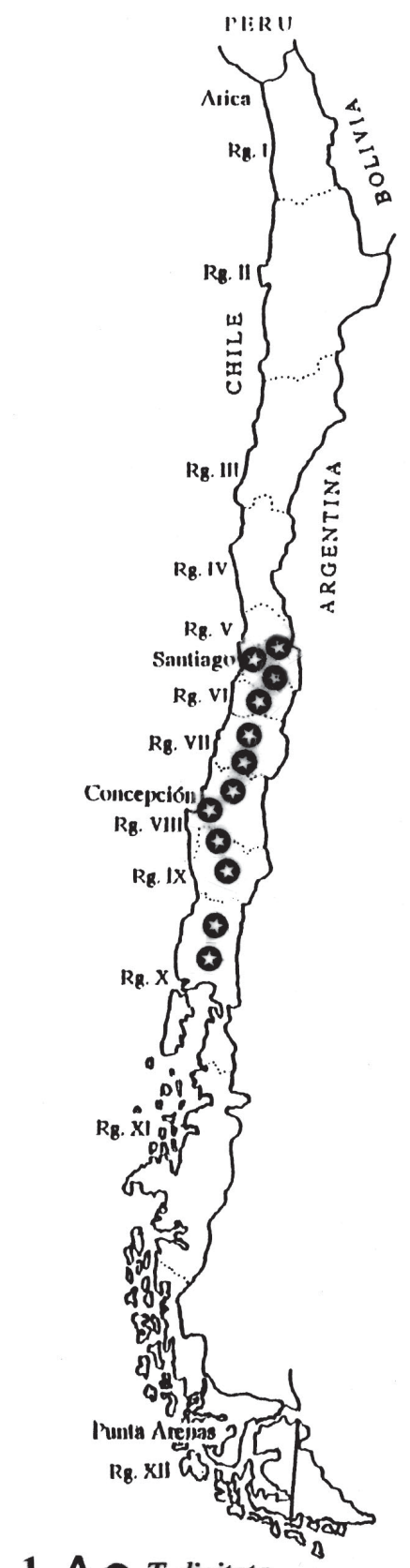

1 A $\odot$ T.digitata

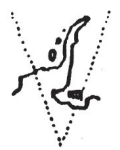

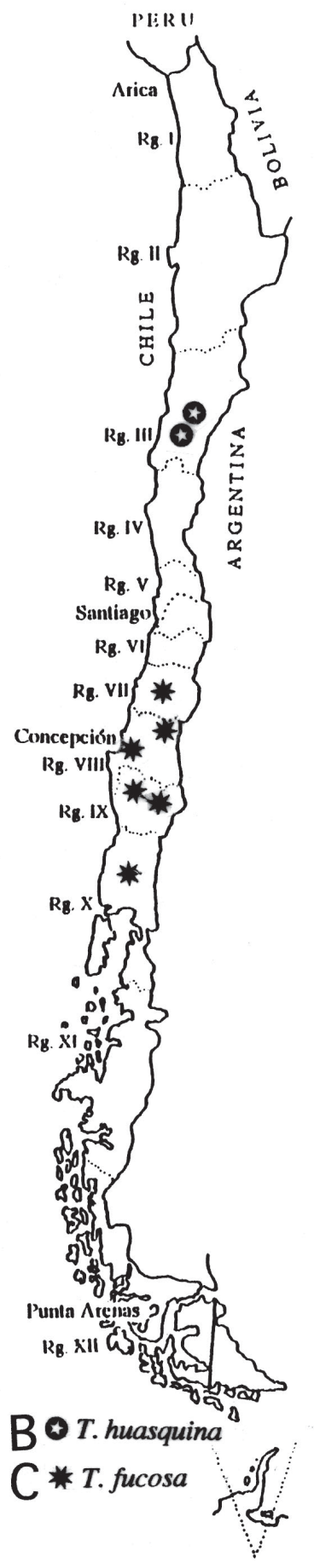

D๑T. fucosoides
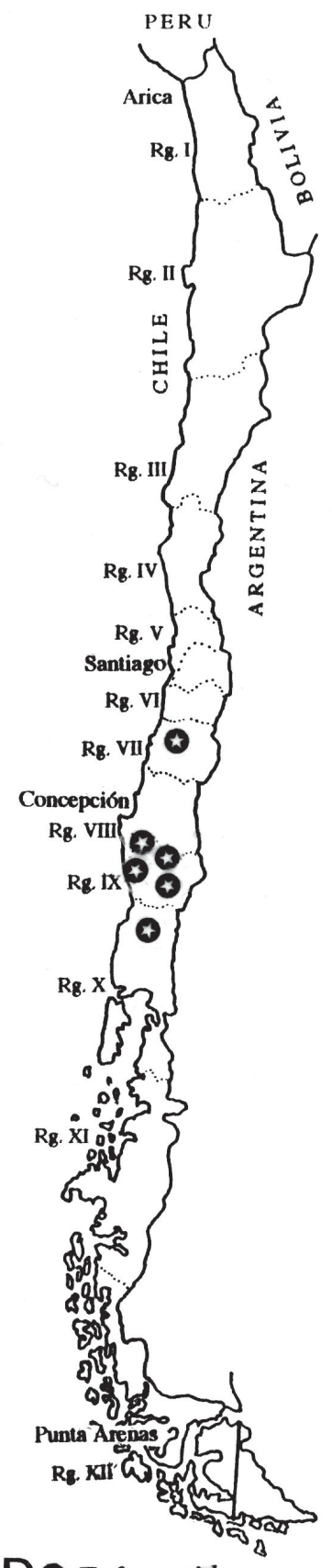

مَ

Fig. 33: Geographic distribution of: (A) T. digitata (Artigas); (B) T. huasquina n. sp.; (C) T. fucosa (Artigas); (D) T. fucosoides n. sp.

Distribución geográfica de: (A) T. digitata (Artigas); (B) T. huasquina n. sp.; (C) T. fucosa (Artigas); (D) T. fucosoides n. sp. 


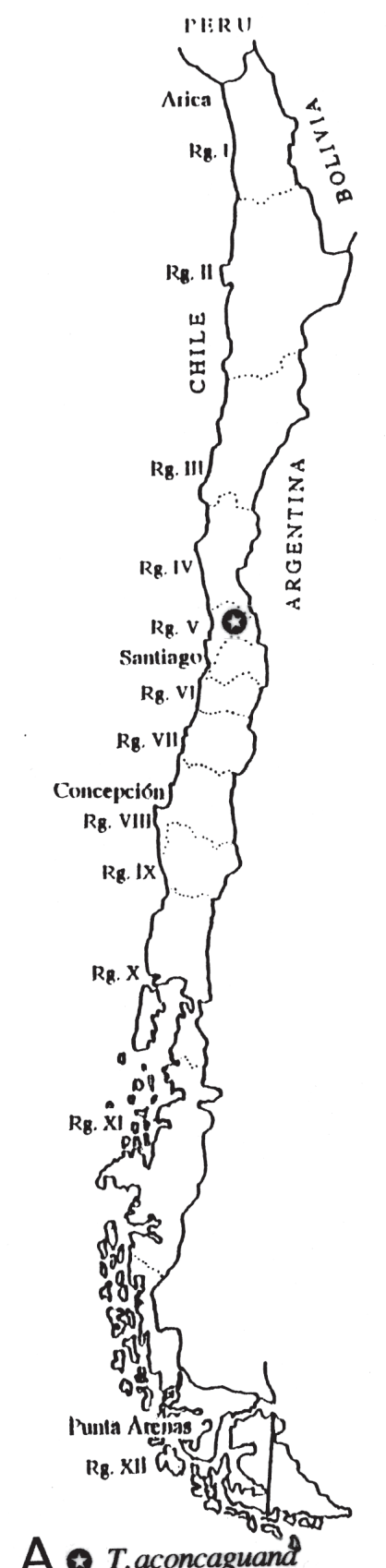

A $\odot$ T.aconcaguana

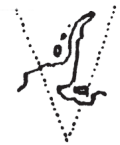

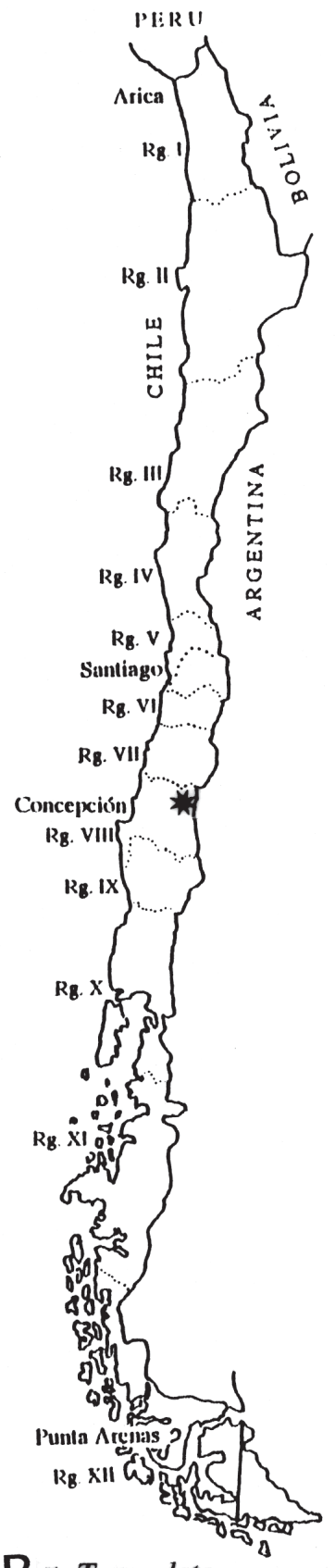

B* T. angulata

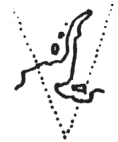

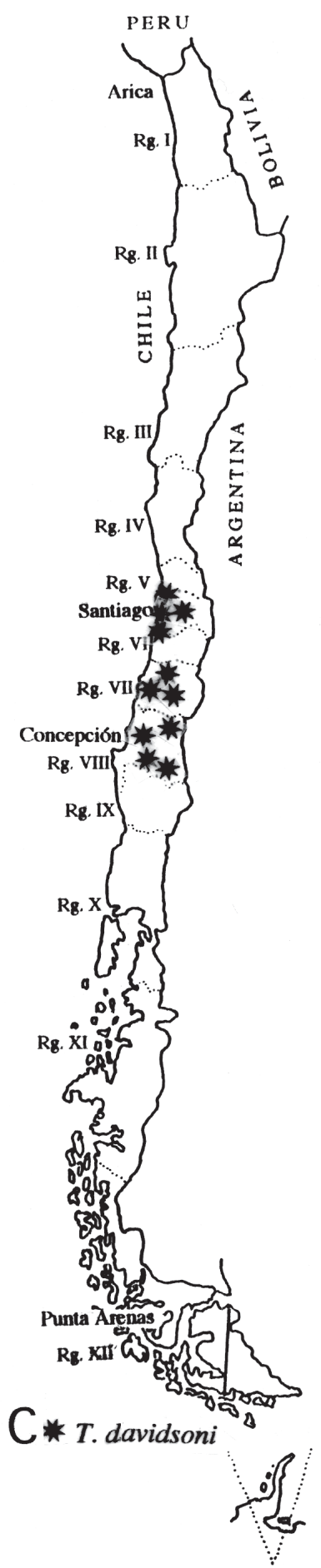

Fig. 34: Geographic distribution of: (A) T. aconcaguana n. sp.; (B) T. angulata n. sp.; (C) T. davidsoni (Artigas).

Distribución geográfica de: (A) T. aconcaguana n. sp.; (B) T. angulata n. sp.; (C) T. davidsoni (Artigas). 
in the reproductive apparatus of both species (only two South African species were studied), and especially the differences in the chitinous structures of the spermatheca, which have a strongly spiraling reservoir for those of the Neotropic (Fig. 3) and a notably globbular one for those of Afrotropics (South African) (Fig. 2D).

The weight given to the spermathecal structures in support of this hypothesis is justified by the fact that it is an internal structure, intimately linked to reproduction and physically committed with the internal organs, like the tracheal system that wraps up it completely. The spermathecae, and the rest of the internal organs, have developed together beginning with their respective imaginal disks. The evolutionary process must have affected them as a whole, producing morphological differences in all of them, possibly of the same magnitude as it is observed for the chitinous structures of the spermathecae. A morphological study of the respiratory, circulatory, digestive, and reproductive apparatuses should provide abundant taxonomic characters in support of the phylogeny, as this morphological study of the spermathecae does. The abundant glandular tissue and the casing that covers the spermathecae chitinous parts, studied in this work, provides important additional morphological characters that were not considered before. This study certainly could have identified more differences between both populations. The difference between a globular reservoir and a spiraled one, creates different physical environments for sperm housing, where a relation between both should necessarily exists to guarantee their viability. When the quantity and distribution of glandular tissue is considered, this connection is accentuated, since it provides the medium and the nutrients for the sperm in the reservoirs lumen (Fig. 6A-6D), where they arrive after passing through the canaliculus cribbed head, inserted in the glandular tissues and connected to the lumen by fine ducts. Since all of the above are related in sequence, the reproductive physiology (including the storage time, fecundation and oviposition) will differ also between species, providing characters so far not used in the taxonomy of the group. Furthermore, the reservoirs (capsules) for both populations are located in different abdominal segments (Fig. 2D and 3), adding another variable. Accordingly, it can be inferred that an important number of internal characters define and distinguish each genus populations. At the present, this is only inferred as a result of the study of the chitinized structures of the spermathecae.

The male genitalia in Asilidae are characteristic for each genus. In Hypenetes hipandrium forms a casing protecting the rest of the genitalia (Fig. 1C and 2A), and is never projected or armed with apical spines, like the ones found in various Tillobroma species (15 of 21) (Fig. 15B and 16B). In both genera, the genitalia are rotated $180^{\circ}$. The epandria differs in their extension: in Tillobroma they never project posteriorly, as in Fig. 12 (note that the genitalia did not retain its normal rotation of $180^{\circ}$ because it was drawn from a sample in $\mathrm{NaOH}$ ); in Hypenetes, the eardrum projects towards the back, as shown in Fig. 3 and 5. In females, the acanthophorites are also different for both genera: in Hypenetes (Fig. 2B) there are about nine spines in each acanthophorite (a total of 18), while in Tillobroma (Fig. 9B), each one posses between five and six spines (a total of 10 to 12). The femora are bicolor in Hypenetes, except in $H$. rexi Londt, where they have uniform black color (Londt 1985: 397), in Tillobroma however, the femora are always unicolor.

The general spermathecae arrangement of the South American Asilidae, as seen after cleared with $\mathrm{KOH}$, show many examples of both models: spiraled capsules (reservoirs) of different thickness and with different numbers of loops, and spherical capsules with or without alterations in the general form (See Artigas \& Papavero 1988: 219, 228, 233 y, 1991: 51-53). There are no genera in which both types coexist, but there are in tribes (Artigas \& Papavero 1991: 44 and 45). A simple structure is considered in general plesiomorphic. In that case, a capsule or plesiomorphic reservoir will have the form of a simple tube with different lengths and thickness, including spherical. The next step is hypothesized to be the thickening along its extension, and because it occupied a limited space within the abdomen, its extension will take a spiral form. Therefore, a spherical capsule is plesiomorphic in relation to a spiraled one. This analysis leads to the idea that the species of the hypothetical ancestral 
gondwanan genus "Hypenetes-Tillobroma" had a spermathecae of global form, and Hypenetes retained this ancestral character.

The spermathecae of Tillobroma always end in three spiraled capsules or reservoirs, which are located between the fourth and sixth segments: the interspecific variation corresponds to the length of the capsular tubes, the form of the expulsion tubes and the spiral loops of the capsules (Fig. 9D, 11G). The spermathecae of Hypenetes grisescens Engel, of South Africa, was studied for this work. It could be inferred that its general plan is shared with most of the other 20 species of the genus, as they do with those of Tillobroma and the rest of the American genera studied (Artigas \& Papavero 1988-1997). The spermatheca of Hypenetes grisescens has three global capsules (Fig. 2D) at the end of the fine capsular ducts, which are located in the seventh abdominal segment. This notable difference in the spermathecae, more than in other characters, provides solid evidence for the separation of the two genera. The hypothesis that both came from different genera and that over time they achieved similarities by convergence is improbable. The spermathecal sclerotized parts, since they were treated with $\mathrm{KOH}$ or $\mathrm{NaOH}$ for the study, are held together by the tracheal system and the rest of the organs in such a way that their arrangement and position in the abdomen is not circumstantial, and that of the capsule structure is even less so, since sperm viability depends on it. In studies on fresh spermathecae (Artigas \& Reyes 1975, Theodor 1985), it was shown that the ducts are covered by glandular tissue, with its distribution along the length of the tubes varying in quantity, and possibly in the type of tissue. This tissue seems to evacuate its products via some fine canaliculi that reach the lumen of the capsular ducts that carry at the end small heads with micropores, as can be seen in Fig. 6A-6D. Theodor 1980: 16-19, Fig. 35 and 36, shows the glandular tissues of the spermathecae and proposes an explanation of their functioning. It is interesting that the structure of the spermathecae, so intimately related to the rest of the systems in the abdomen of Asilidae, is a structure subject to significant evolutionary change, with apparently greater occurrence than the external parts, especially the tegumentary elements.

\section{Biology of Tillobroma}

There is no information available on the biology of the species of this genus, or species of the South American Asilidae genera, except for the species Mallophora ruficauda Wied. (Copello 1922 and 1927). General anecdotal information on the species of the genus Tillobroma is available: grassy environments that developes in wetland, strong territorialism and some selectivity on its prey. Territorialism has been observed also in the collection of the same species in successive seasons from the same places. Individuals of Tillobroma collected in Chile have survived only a few hours in captivity cages, usually less than one hour, because they have the tendency to fly straight and fast, which results in a crash against the cage that severely injuries them. It seems not possible that accidental movement could produce its dispersion.

Like all Asilidae, their feeding begins with the capture of prey in flight. After a struggle in the air, they paralize it and consume their internal juices, while hanging from a branch. They select their prey to certain extent, and do not accept prey provided in captivity, which prevents the possibility of rearing them or maintaining a culture. There is no information about their larval stages, and theoretically they live in damp soil or in substrates with some humidity (in the desert) where they feed on the larvae of other insects.

\section{Geographical distribution}

The known distribution of Tillobroma species is south of the 15 parallel in South America (Fig. 30F). The majority of the species (17), have been recorded only in Chile, two species are known from both Chile and Argentina, one species is found only in Argentina, and two species are known only from Brazil. Some scarce, unidentified material is known from Bolivia, Paraguay and Peru, but it is in such poor condition that it was left out of this revision. Table 2 presents the known distribution for the species in Chile, organized by Region and month of collection (526 samples from the Universidad de Concepción Zoology Museum). Most collections concentrate between Regions VII and X from January to March, and in the V and Metropolitan Region from August to 
November. Table 2 also indicates the locations with most frequent collections. Future collections, covering more areas and dates, will clearly modify the current distribution of Tillobroma known in Chile. Known distributions of the 21 species treated are provided in the maps (Fig. 30A-34B). It is expected that other species will be described for this genus, especially from material collected in grasslands of Paraguay, Peru, Bolivia and Brazil.

\section{CONCLUSIONS}

(1) Hypenetes Loew and Tillobroma Hull are sister genera, possible of Gondwanan origin. (2) Hypenetes is the genus of the species that currently occur in South Africa, and Tillobroma is the genus for the South American species. (3) The definitive separation of these genera, that 180 million years ago possible formed a single genus, was produced by the division and drift of the Gondwana Continent, homeland of South American and African ancestral genus. (4) The species of both genera can be positively separated by the spermathecae structure, which is a global capsule (reservoir) in Hypenetes and spiraled in Tillobroma. It is inferred that this anatomical difference, which comprises other internal structures, should result in sufficient character accumulation to allow the affirmation of genera separation. (5) The 10 new South American species presented in this work, with their characters, demonstrate that Tillobroma is a well-defined and taxonomically stable genus. (6) The phylogenetic tree of strict consensus shows a great amount of homoplasy between Tillobroma species, however nine synapomorphies easily separate Hypenetes from Tillobroma. (7) The known species of Tillobroma are distributed in South America south of parallel 15 .

\section{TABLE 2}

Geographic and temporal distribution of the 18 species of Tillobroma known to Chile: one aconcaguana n. sp., two angulata n. sp., three asiliformis (Wulp), four critesi (Artigas), five davidsoni (Artigas), six digitata (Artigas), seven fucosa (Artigas), eigth fucosoides n. sp., nine huasquina $\mathrm{n}$. sp., 10. leucoptera n. sp., 11. leucotrica n. sp., 12. magellanica (Artigas), 13. nahuelbutae n. sp., 14. punctipennis (Philippi), 15. purpurea n. sp., 16. schineri (Artigas), 17. tregualemuensis n. sp., 18. valentinei (Artigas). Roman numbers identify political regions of Chile

Distribución geográfica y temporal de las 18 especies de Tillobroma conocidas en Chile: uno aconcaguana n. sp., dos angulata n. sp., tres asiliformis (Wulp), cuatro critesi (Artigas), cinco davidsoni (Artigas), seis digitata (Artigas), siete fucosa (Artigas), ocho fucosoides n. sp., nueve huasquina n. sp., 10. leucoptera $\mathrm{n}$. sp., 11. leucotrica n. sp., 12. magellanica (Artigas), 13. nahuelbutae n. sp., 14. punctipennis (Philippi), 15. purpurea $\mathrm{n}$. sp., 16. schineri (Artigas), 17. tregualemuensis n. sp., 18. valentinei (Artigas). Números romanos corresponden a las regiones políticas de Chile

\begin{tabular}{|c|c|c|c|c|c|c|c|c|c|c|c|}
\hline Month & I II & III & IV & V-RM & VI & VII & VIII & IX & $X$ & XI & XII \\
\hline January & & & & 6 & & $5,8,14,18$ & $5,7,8,14$ & $4,8,13,18$ & $4,7,8,12$ & & 4 \\
\hline February & & & 18 & & & $7,16,17$ & $4,5,6,7,8$ & $4,8,13,14$ & 4,18 & 4 & 4,12 \\
\hline March & & & & 5,16 & 10,16 & $5,6,16,17$ & $4,5,6,14$ & $6,12,13,14$ & $4,5,6$ & & \\
\hline April & & & & $5,6,10,16$ & & $5,16,18$ & 5,6 & & & & \\
\hline May & & & & & & & 6 & & & & \\
\hline June & & & & & & & 7 & & 4,6 & & \\
\hline \multicolumn{12}{|l|}{ July } \\
\hline August & & 11 & & $1,5,15$ & & & & 18 & & & \\
\hline September & & 9 & & 5,15 & & & 2 & & & & \\
\hline October & & 9 & 18 & 6,15 & & 18 & 2 & & & & \\
\hline November & & & 18 & 5,18 & & 18 & & 7,13 & & & 3 \\
\hline December & & & 18 & 18 & & 18 & $4,5,18$ & 13 & & & 3 \\
\hline
\end{tabular}




\section{ACKNOWLEDGEMENTS}

We thank the Research and Development Department of Universidad de Concepción (DIUC 97.113.042-1.0) for their support to the development of this work, the Zoology Museum of Universidad de Concepción (MZUC-UCCC), especially Ms. Elvira Solar for her outstanding work in preparaing the manuscript and other necessary computer tasks and Mrs. Minerva Contreras for their permanent collaboration in the handling of the study material. We also thank Miss Jane Simons and Dr. Tania Zaviezo for their help with the English version.

\section{LITERATURE CITED}

ARTIGAS JN (1970) Los Asílidos de Chile (Diptera: Asilidae). Gayana Zoología 17: 472 pp.

ARTIGAS JN \& E REYES (1975) Aparato reproductor de las hembras de tres especies de asílidos chilenos, con énfasis especial en la estructura de las spermathecae (Diptera: Asilidae). Boletín de la Sociedad de Biología de Concepción (Chile) 44: 195-205.

ARTIGAS JN \& N PAPAVERO (1991) The American genera of Acaridae (Diptera): keys for identification with an atlas of female spermathecae and other morphological details. VII.1. Subfamily Stenopogoninae Hull. A preliminary classification into tribes. Gayana Zoología (Chile) 55: 139-144.

ARTIGAS JN \& N PAPAVERO (1991) The American genera of Asilidae (Diptera): Keys for identification with an atlas of female spermathecae and other morphlogical details. VII.5. Subfamily Stenopogoninae Hull - Tribe Tillobromini, with descriptions of three new genera and two species and a catalogue of the neotropical species. Revista Chilena de Entomología 19: 17-27.

BROMLEY SW (1932) Diptera of Patagonia and South Chile, based mainly on material in the British Museum (Natural History). Part 5, fascicule 3: 201293.

BROMLEY SW (1946) Asilidae Stuardo-Ortiz C. In: (ed) Catálogo de los dípteros de Chile. Ministerio de Agricultura, Santiago, Chile: 253 pp.

COPELLO A (1927) Biología del moscardón cazador de abejas (Mallophora ruficauda Wied.). Argentina. Ministerio de Agricultura, Buenos Aires, circular $\mathrm{n}^{\mathrm{o}}$ 699, 19 pp., 10 figs.

ENGEL EO (1930) Die ausbeute der deutschen ChacoExpedition 1925-1926, Asilidae (Diptera). Konowia, volumen 8 (1929), pp. 457-474, 8 figs.
GOLOBOFF PA (1993) NONA. Versión 2.0 (Windows). Computer program, distributed by the author.

HULL FM (1962) Robber flies of the World. The genera of the family Asilidae. Smithsonian Institution, United States Natural History Museum, Bulletin 224, part 1, 1-432, part 2: 433-907.

LOEW H (1858) Bidrag till Kännedomen om Afrikas Diptera (part). Öfvers. K. Vetensk Akad. Forh. Stockh (Stockholm) 14: 337-383.

LONDT JGH (1985) Afrotropical Asilidae (Diptera). The Genus Hypenetes Loew, 1858 (Dasypogoninae). Annals Natal Museum (Brazil) 26: 377-405.

MACQUART PJM (1834) Histoire naturelle des insectes. Dipteres. Suit a Buffon, edited by Roret. Vol. 1, pp. 1-578, 12 pls. (Asilidae pp. 275-317, pl. 7, figs 6a, b, 10).

MACQUART PJM (1846) Dipteres exotiques nouveaux ou peu connus. First supplement. Paris. Libraire Encyclopedique de Roret. Lille. 58-97, 3 pls.

McALPINE J (1981) Manual of Nearctic Diptera. Volume 1. Research Branch of Agriculture, Canada. Monograph № 27.

MARTENS E von (1860) Die Heliceen nach natürlicher Verwandtschaft systematisch geordnet von Joh. Christ. Albers. Zweite Ausgabe. W. Engelmann, Leipzig. xviii +359 p.

NIXON KC ed (2002) Winclada ver. 0.9.99.50.mexu (beta) New York, Ithaca, USA.

OLDROYD H (1974) Some comments on the tribal classification of Asilidae (Diptera). Israel Journal of Entomology 9: 5-21.

PAPAVERO N (1973) Studies of Asilidae (Diptera). Systematics and Evolution. I. A preliminary classification in subfamilies. Museu Zoologia Universidade São Paulo 23: 217-274.

PHILIPPI RA (1865) Aufzählung der chilenischen Dipteren. Verhand1. K.-K. Zool.-Botan. Gesell. Wien 15 (Abhandl): pp. 597-782, 7 plates.

REED EC (1888) Catálogo de los insectos dípteros de Chile. Anales Universidad de Chile 73: 1-46.

SCHINER JR (1868) Diptera. Reise der Oesterreichischen Fregatte Novara 1857-59. Zool. Theil (Wien) 2: 155-195.

STUARDO C (1946) Catálogo de los dípteros de Chile. Ministerio de Agricultura, Dirección General de Agricultura, Imprenta Universitaria, Santiago, Chile $250 \mathrm{pp}$.

SWOFFORD D \& G OLSEN (1990) Phylogeny reconstruction. In: Hillis DM \& C Moritz (eds) Molecular systematics: 441-501. Sinauer Associates, Sunderland, Massachussets, USA.

THEODOR O (1980) Fauna palaestina. Insecta II Diptera: Asilidae. Israel Academy of Sciences and Humanities, Jerusalem, Israel. 448 pp.

TORRE-BUENO JR DE LA (1989) Glossary of entomology. The New York Entomological Society, American Museum of Natural History, New York, USA. $840 \mathrm{pp}$.

WULP FM VAN DER (1882) Amerikaansche Diptera. Tijdschrift voor Entomologie 24: 77-136.

WULP FM VANDER (1882) Americaansche Diptera. Tidjdschrift voor Entomologie 25: 101-103, pl. 10. 


\section{APPENDIX 1}

Abbreviations used in this study

Abreviaciones utilizadas en este estudio

\begin{tabular}{|c|c|c|c|}
\hline acanth & acanthophorite & kepm & katepimeron \\
\hline aed & aedeagus & kepst & katepisternum \\
\hline anat & anatergite & $\mathrm{ktg}$ & katatergite \\
\hline anepm & anepimeron & lab & labium \\
\hline anepst & anepisternum & lac & lacinia \\
\hline apod-ey & ejaculatory apodeme & lbr & labrum \\
\hline aprm & antepronotum & $\mathrm{mi}$ & mystax \\
\hline bas & basistylus & $\mathrm{mn}$ & mentum \\
\hline bo & mouth & $\mathrm{mr}$ & meron \\
\hline bst & basitarsus & mtepm & metepimeron \\
\hline $\mathrm{ca}$ & face & $\mathrm{mtg}$ & metategite \\
\hline canali & canaliculus & mtkepst & metakatepisternum \\
\hline cap-res & capsule-reservoir & $\mathrm{mtn}$ & metanotum \\
\hline $\mathrm{cd}$ & cardus & $\mathrm{n} 1$ & pronotum \\
\hline cdet & dosocentral bristles & no gen & without genitalia \\
\hline ce & cercus & o & eye \\
\hline cintra & intraalar bristles & ped & pedicele \\
\hline cntpl & notopleural bristles & $\mathrm{pgl}$ & paraglossa \\
\hline cposcut & postscutellar bristles & pl 1 & propleuron \\
\hline $\mathrm{cuP}$ & lower basal cell (third basal) & $\mathrm{pmx}$ & maxillary palpus \\
\hline $\mathrm{cx} 1$ & front coxa & poc & postocular (area) \\
\hline $\operatorname{cx} 2$ & middle coxa & presct & prescutellumn \\
\hline $\operatorname{cx} 3$ & hind coxa & $\mathrm{pscl}$ & postscutellum \\
\hline dist & dististylus & pul & pulvillus \\
\hline duc-cap & capsular duct & sctll & scutellum \\
\hline duc- com & expulsory duct & sp 1 & anterior spiracle \\
\hline ecv & cervical sclerite & sp 2 & mesothoracic spiracle \\
\hline emp & empodium & sperm & spermatheca \\
\hline ep & epandrium & stn 1 & first sternite \\
\hline esc & scape & $\operatorname{stn} 7$ & seventh sternite \\
\hline espin & spine & $\operatorname{stn} 8$ & eighth sternite \\
\hline fl & flagellum & $\operatorname{stn} 9$ & ninth sternite \\
\hline fl I & first flagellomere & $\operatorname{stn} 10$ & tenth sternite \\
\hline fl II & second flagellomere & str & transverse suture \\
\hline $\mathrm{fm} 3$ & hind femur & tb 1 & front tibia \\
\hline fr & front & tb 3 & hind tibia \\
\hline fu-aed & aedeagus sheath & $\operatorname{tg} 1$ & first tergite \\
\hline$g f$ & facial gibosity & $\operatorname{tg} 2$ & second tergite \\
\hline $\mathrm{gl}$ & gland & $\operatorname{tg} 8$ & eighth tergite \\
\hline gp & gonopod & $\operatorname{tr} 2$ & middle trochanter \\
\hline hal & halter & ts 3 & hind tarsus \\
\hline hip & hypopharynx & $\mathrm{u}$ & claw \\
\hline hyp & hypandrium & vtx & vertex \\
\hline
\end{tabular}

